\title{
GARDENS AND THEIR MEANING
}

\section{DORA WILLIAMS}

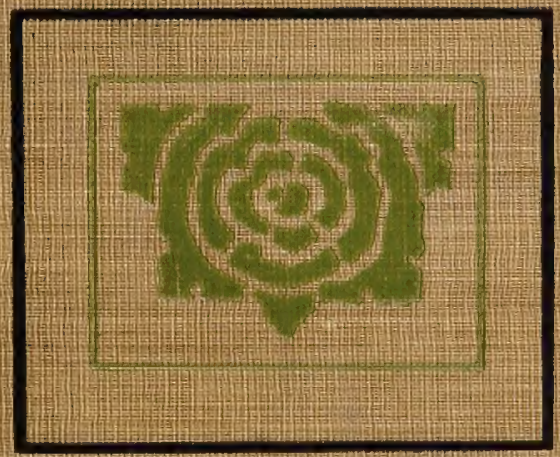




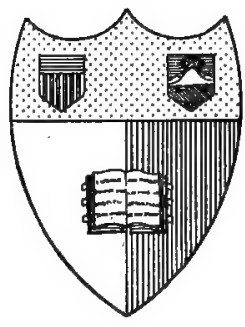

\section{Avew \\ State Gollege of Agriunlture}

At Garnell Mlniwersity

Ithaca, 2. 19.

\section{Tithraxy}




\section{SB 453 Cornell University Library}

Gardens and their meaning, by Dora Willi

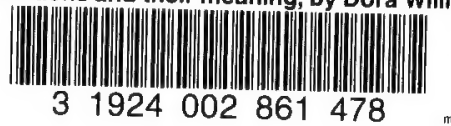

3 1924002861478 


\section{Cornell University Library}

The original of this book is in the Cornell University Library.

There are no known copyright restrictions in the United States on the use of the text. 




\section{GARDENS A N D \\ THEIR MEANING}

BY

DORA WILLIAMS

GINN AND COMPANY, PUBLISHERS BOSTON - NEW YORK - CHICAGO - LONDON L. 
COPYRIGHT, 1911, BY DORA WILLIAMS ALL RIGHTS RESERVED 911.12

(a)

$0-4=3$
45

$0 y+10065$

Che atbenaum press

GIN AND COMPANY - PRO-
PRAETORS - BOSTON + U.S.A. 


\section{PREFACE}

The aim of this book is twofold: to show the importance of science in the use of spade and hoe; and to urge that a garden for education may be, not merely in substance but in spirit, a corner of the great world. Protected it certainly should be, but not walled in. Outside and within the garden precincts are at work nearly identical social forces, and the same joys and sorrows. The interchange not only of sympathy but of plans and projects will be frequent. Thus the path between the big and the little world must be free and unrestricted. It will not be a "one-way road"; the gate swings easily in both directions:

It is not to be expected that these suggestions will appeal equally to everybody. There are, in fact, many persons who are satisfied with the schooling that deliberately takes young folks out of real life for a time and then puts them back again. It is hoped, however, that this little volume will make friends among the hosts of parents, teachers, and social workers who are trying to increase community efficiency by giving opportunity for richer life during school years. I shall indeed be content if through words of mine their happy task shall in any way be lightened.

Many have helped, both consciously and unconsciously, in the making of this book. They are indeed so many that, to my regret, in expressing here my gratitude I cannot call each friendly contributor by name. 
There are some, however, to whom I am peculiarly indebted. First among these is Dr. Colin A. Scott, to whom I owe the Social Education note in the book and whose criticisms have been of the greatest value. Dr. David F. Lincoln and Dr. George W. Field have put their time and experience at my service and have generously reviewed the manuscript. Professor Thomas N. Carver of Harvard University, Edward M. Forbush, Massachusetts Board of Agriculture, Loring Underwood, and John Graham Brooks have been so kind as to read critically certain chapters. To Miss Elizabeth Mailman, of the Rice School, Boston, I am deeply grateful for her constant coöperation in the practical work with children.

My acknowledgments would be incomplete without mention of the Education Committee of the Twentieth Century Club, under whose auspices, friendly and financial, probably the first real city garden on this side of the water was started, and of the Boston School Garden Committee, by means of whose stanch support further pioneer work, under the devoted leadership of Miss Anne Withington, was made possible.

My own collection of photographs has been substantially increased through the interest of friends. Among those who have contributed with great generosity, and whom I wish especially to thank, are Miss Elizabeth Hill of Groton, and my friends Mr. and Mrs. H. B. Fullerton of Medford, Long Island.

DORA WILLIAMS 


\section{CONTENTS}

PAGE

\section{INTRODUCTION}

The garden a combination of space and power. Agricultural possibilities shown in small areas. Children as producers. The advantage of the productive life. A garden teaches beauty and good order. It reveals nature's laws. Parents recognize the value of children's gardening. A garden the pivot of family life. Social forces are let loose. A garden gives respect for law and order, and a chance for honorable profit and for the coöperative life.

\section{CHAPTER I. WHAT MAKES A SCHOOL GARDEN WORTH} WHILE

Gardening in the school program. Influence of the garden upon the school. Work-mates. Mutual aid. The real school garden is worked and planned by children. Difficulties. A philanthropist's garden. School gardens at Hampton, Virginia. Gardening in graded schools. The teacher's contribution. The school garden an organism. Placing responsibility upon children. Study of child types. Development of initiative. Opportunities for investigation. Visits to model gardens. Respect due to the farmer. Results obtained. Garden ownership : communal, individual, or coöperative. Efficiency balanced against-coöperation. Incidental values of gardening. Practice in the art of living.

\section{CHAPTER II. LITTLE STUDIES IN COÖPERATION . . .}

Science and coöperation prominent in a successful school garden. Both necessary in school and in life. The making of leaders. Competition in school life. Coöperation. Self-organized garden work. Girls' report. Reactions of different temperaments to coöperative work. The dull boy. The teacher's comprehension enlarges. A school program will provide exercises in coöperation. 
Hebted.

CHAPTER III. SITUATION AND SOIL. . .

The school garden a form of outdoor laboratory. Size " ' n

tively unimportant. Window gardens in Boston. The 16 ....ulu. $\mathrm{id}$ Sunshine a necessity. Adaptation of the school yard Use of the $1 d$ vacant lot. Park lands. Transfer of classes. Transfc ition of $o$, at school yard. Fence or no fence. Soil testing. Treatm th of the lane tt. Enrichment by manure, guano, ashes, prepared dressings, and str sweepings. Skimming the land. Green manure. I sulating peas with nitrogen bacteria. The compost heap, Garden econor.

\section{CHAPTER IV. PLOTTING AND PLANNING}

Waste no space. Plotting done with care and deliberation. Plotting and planning the business of pupils, not teachers. Practice in arithmetic. Contrivances simplify measuring. Plan drawn to sca'r $\mathrm{Tr}$ kitchen garden; flowers, experimental beds, cold frame. ¿ $\mathrm{C}_{2}$ cannot plan as far ahead as elders. Arrangement of flowering Plus Arrangement of vegetable beds. Visit to a model market garis School gardening must not be merely an imitation of a market ga: Arrangement adapted. Self-organized work for groups. False idea. arrangement. Reactions to the responsibility of planting and plotting. Experimental beds develop scientific interest. Some schoolboys plan to raise rice. Plotting and planning a garden is good discipline.

\section{CHAPTER V. A WORD FOR GOOD TOOLS.}

A clamshell for a tool. Need of the right implements. A visit to an agricultural supply house. History of agriculture told by tools. Three generic tools. A simple outfit. Cost. Coöperative ownership of expensive tools. Avoid cheap tools. Care of tools and tool house. Inspection made by the children. Woodworking tools a valuable supplement to a garden outfit. Suitable dress.

Idle land claimed by weeds. The planting season lasts the year round. Three periods : early, midsummer, and late. Plant nourishment. Crop rotation as opposed to the one-crop system. Foods supplied at different depths. Shifting crops. Kinds of crops : catch crops, cover crops, green manure. Devices in planting. Quality of seed. Where to buy. How to recognize good seeds. A simple rule for testing 
a whole farm tested by a schoolgirl. Preparation of 'g. The ideal soil resembles soot. Seeds grown in

$\therefore$ ip others. Distance apart and depth. A planting $.4 \mu_{2}$. 1. to rules for planting different kinds of seeds. Chilэre averse "thinning out." Seeds planted instead of sown. $\mathrm{n}$ the prot of planting: drilling, laying in seeds, packing, Ing, labeling 3 indoor planting for future transplanting; for exn.ts. Growing under glass. How to make a cold frame. A hotis ing bulbi, fI

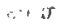

Tending the soil follows planting. A caked soil sheds water. The roots starve; weeds take possession. A dust blanket conserves moisCultivation or dry farming. The art of watering. A plant tonic. 3 grand scale: at Milan, in Dakota. Irrigation for little Vever expose seedlings to a hot sun. Plants easy to trans$\checkmark$ 'ices for transplanting. Setting out shrubs. A few favorite " od luck in gardening means devotion.

CHAPTER VIII. JUST HOW . . . . II2

Beans: Warm, dry soil. Moisture. Several plantings. Beware of rust. Beets : Rich, light soil. Constant cultivation. First thinnings for greens. Cooking. - Cab. $\quad:$ Cabbage the whole year through. Three varieties. Generous manuris The cabbage worm and other enemies. Cooking. A cabbage gone to seed. The cabbage tribe. - Carrots: The earth well tilled. Cultivate carefully. Early carrots and late. Cooking. Lettuce: Cos and cabbage. Indoor planting. Cultivate constantly. Preparation for table. - Onions: Sets or seeds. Rich earth. Cultivation important. Root maggot, smut, and blight. - Parsley: Slow germinating. Medium soil. Cultivate well. Use as garnish and seasoning. - Radish: Three varieties. Fine, rich earth. Soil well worked. Plant successively. Thin well. Store winter radishes in sand. - Spinach: Secure: jick growth by plant tonic. Record of one garden. Preparation for the table. - Tomato: The original tomato. Plant early. Transplant several times. One ounce gives two thousand plants. Fertilize with manure. Plants must not spindle. Make supports. Pick fruit as soon as ripe. Tomato worm. - Herbs: Mint, parsley, sage, and thyme. Peppermint, lavender, and catnip. Light earth. Cultivate well. Dry in the garret. 
The gardener a sponsor for his plants. Weeds have potential value. Cultivation of weeds and unfamiliar plants. Learn to know common weeds. Weeding with the hoe. Sterilizing soil not practical. A cheerful weeder. Fungus enemies: potato scab, bean rust, corn smut. Insect enemies. Food destroyed yearly by insects. Families should unite to exterminate them. Mouth parts. Chewing insects destroyed by poison; sucking insects destroyed by emulsion. Recognize insects in various stages. The cabbage butterfly. Potato beetle. Hibernation. Stir soil, leaving it rough during winter. Habits of corn worm, cucumber beetle, rose beetle, cutworm. These insects afford material for nature study. Insect friends : lady beetle, tiger beetle, ichneumon fly, dragon fly. The toad. The earthworm. Children's attitude toward worms. Our debt to birds. The gardener's pledge.

Protecting the birds. Birds that will nest in boxes. Flickers in summer cottages. Bluebirds. Adaptation of bird houses to their occupants. Glass side gives chance for observation. Insulation of a martin box. Provision for drinking and bathing. A bird fountain in Worcester. Bees. An observation hive at a Boston school. Bees in London at the Nature Study Garden; at an English home school. Poultry at the Hyannis Normal School. A rain gauge. How to measure rainfall. Woodworking and gardening. The sundial and its construction. Mottoes. Beauty a feature of children's gardens. Arbor, pergola, summerhouse. Backyard possibilities. In Salem. In an English factory town. Increase in comfort and pleasure.

\section{CHAPTER XI. NEW LIFE IN OLD SUBJECTS . . . 159}

Children not often prepared for the life immediately before them. Old education academic. School exercises to-day consist of two sorts : real activities and the acquiring of tools. Real activities increase in preparation. Children's compositions. Gardening vitalizes the school curriculum. The demands made by gardening include almost the entire school course in arithmetic. It develops the business sense. Garden subjects basis of real letters. Geography. The artistic sense; drawing. Good cooking encouraged by growing the foodstuffs. Nature-study material. Nature study is made less artificial. The beginnings of scientific investigation. The nature-study teacher relieved of strain. Teacher and 
children follow together the scientific method. Freedom from the old-style course of study. Little housekeepers. Wasted school days. Gardening adapted to the demands of new methods.

Gardening all the year round. Calendar for a twelvemonth. The summer holidays. Neglect of one garden means injury to all. Measures adopted to make work continuous. School-garden records. A boy's diary.

\section{CHAPTER XIII. TIIE NEW AGRICULTURE}

School gardening leads to a life interest in agriculture. Study of country conditions. The large producer contrasted with the struggling old-time farmer. The expert wins. Present European conditions. The revolt against ignorance and oppression. Coöperative agriculture in Ijelgium and France. The "coöperative" a means of education. Mutual aid a fundamental principle of life. Need of scientific knowledge and coöperation among the farmers of our own country. Efforts that are being made to spread modern methods and to unite the farmers. Begin with the children. Train young people in coöperation and in science. School gardens are a preparation for the new agriculture. 



\section{GARDENS AND THEIR MEANING}

\section{INTRODUCTION}

Train the children, each in its own little garden, to respect fruit trees, honorable profit, industry, beauty and good order: it is the summary of all Gospels to man. - "New Letters of Thomas Carlyle."

"Space to let with power." This sign advertises the resources of a large machine shop. Space with power. What words could better describe a garden? The space is selfevident. The power, they say, no man has ever fully measured. It is a wonderful combination of sun, rain, and the invisible forces of the soil. This power is all ready to be turned on. All it needs is men who are skillful enough to guide it.

Thus looked upon, a garden is a great fact. We realize, however, that its importance does not depend upon its size. Small plots may have great meaning. They not only vitally affect the economies of a nation, but, rightly understood, they give insight into the great movement of agriculture. At the outset it is well to remind ourselves that agriculture is as truly a social problem as a scientific one. That is to say, it involves not only wheat and corn but human beings as well. In these pages, therefore, we propose to study a very small garden, which shall be carried on by very young people.

Carlyle hit it when he said that children could be trained in their little gardens to respect fruit trees, honorable profit, 
beauty, and good order. Surely any combination of space and power which, rightly utilized, could produce results so essential for citizenship would be well worth the price. By "honorable profit" he means, of course, profit through production. Plainly this is a garden's special contribution. Children in this way become producers. Any ten-year-old who raises a handful of radishes for breakfast, a fine head of cabbage for dinner, and a bunch of sweet peas for "mother's table" has already tasted the delights of the productive life. Having thus early become a producer, a boy or girl in later life will hardly be satisfied with the treadmill existence of the middleman. The result will be that we shall get more first-rate producers and fewer second-rate citizens.

That society to-day is swarming with middlemen - with clerks and agents and bookkeepers - we are well aware. Though useful in making wealth available, this class adds nothing directly to the wealth of the world. Besides, the supply far outstrips the demand. In consequence the average middleman leads a life that is joyless and poorly paid, and he is, moreover, haunted continually by the fear of being displaced by young and eager applicants. For this overwhelming proportion of "go-betweens" we have ourselves to thank. It is the logical outcome of the schooling that has been dealt out to country and city children alike, fitting them almost exclusively for the clerical, the "clean-handed," occupations.

How easy for a young person to drift into this current. On approaching their teens boys and girls get restless. They long to push out a little into the larger world. Fathers and mothers see no harm in this. They see, on the contrary, certain advantages in letting children enlarge their horizon and satisfy their love of adventure by getting into a wholesome relation with the real activities of the world. The youngsters, on reaching the crossroads, naturally take the beaten path. 
They follow the lines of least resistance and catch up some sort of trading. They sell papers, perhaps, or peddle eggs from the country on commission. In one neighborhood, for instance, a lad, last winter, became agent for a brand of chocolate. In the business district, among prominent men whose offices he visits at stated intervals, he soon worked up a regular route. In accordance with a watchful father's counsel his small business is conducted with an exactness that might represent thousands.

From the viewpoint of just one boy this experience is admirable. But the field should be surveyed as well from a different angle. It is plain that in such cases the youngsters are becoming in truth small shopkeepers - in a word, middlemen. Each day they gain a little more skill and a little more interest in negotiating cleverly between producer and consumer. This is exhilarating. They do not realize, nor do we, that they are being inevitably sucked into the ever-rising flood of middlemen.

Of producers and organizers, on the other hand, the world has always had too few. This fact is thrust upon us a dozen times a day. We owe it, therefore, to our young people to give them at least a try at some occupations that are genuinely productive. Afterwards the successful working out of some real sort of breadwinning is easy. Described in the language of the seedsmen: Seeds for this variety must be sown very early, in order that the roots may strike deep. Later the plants require little or no care. These plants when full grown are hardy; they bear wonderfully, and, though not gaudy, are unsurpassed in beauty and in flavor.

When, however, young people have raised salable fruit, flowers, or vegetables, by all means let them enlarge their horizon by going with their own produce to market. In this way they can study supply and demand, prices, and other 
business questions, as these directly affect the goods they want to dispose of. They will see the wisdom of keeping strict accounts, a practice only too frequently neglected among farmers as a class. All these practical issues, moreover, will

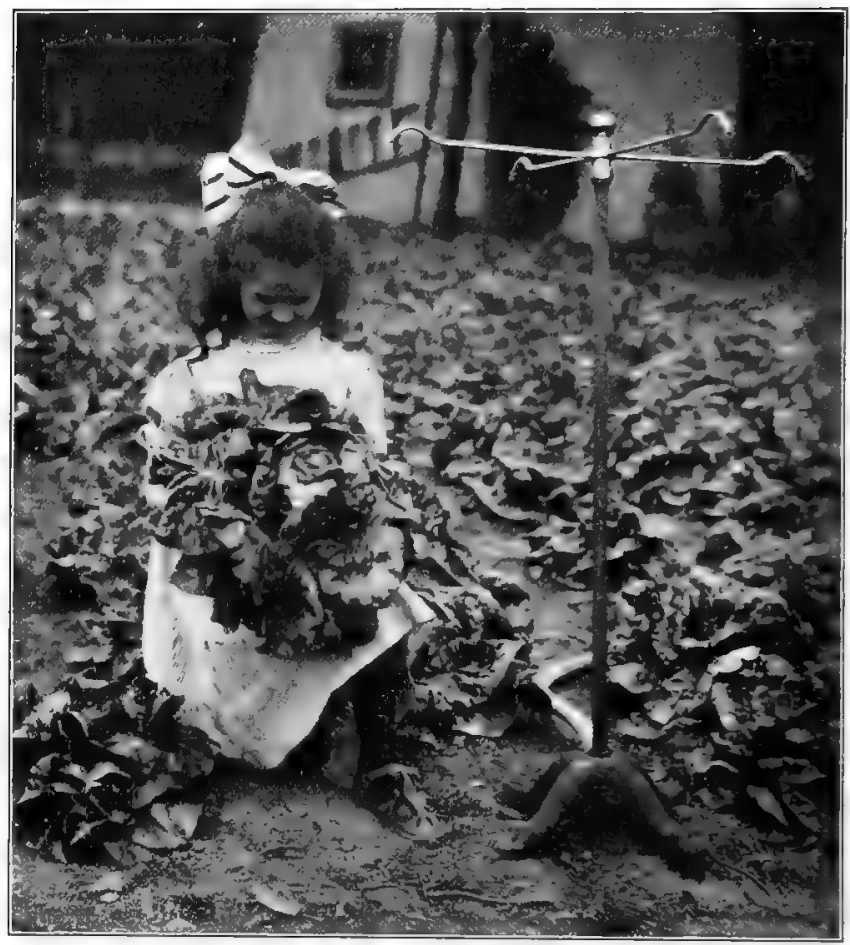

A YOUNG PRODUCER

materially help them in deciding what to specialize in. This is not mere theory. These ideas are now being worked out in many places. In some neighborhoods children actually have their regular customers, and deliver from little pushcarts the fresh-picked flowers or vegetables which they 
themselves have grown. In thickly settled communities customers sometimes come to the garden to buy.

We can bring no more convincing proof of how garden stuffs may be raised in a small plot for neighborhood sale than has been given in a certain vacant city lot in upper New York. At headquarters, consisting of a couple of tents, the young producers kept their tools, their three-foot library of garden books, and their account books. Here they transacted business, and part of the time - just for the lark of it - actually camped out. Neighbors came over daily for fresh vegetables. "Lettuce six cents, instead of eight at the store, and right out of the garden," called out a little girl in answer to a visitor's inquiry, as she sped homeward with an armful.

Carlyle, as we have seen, begins with the question of profit, but he does not end there. The joy of production does not stop with the satisfaction derived from a dime or a boiled dinner. Some of us can match the feelings of a prominent New York business man who tells how he spent all his odd moments, during a whole summer, out in his garden raising squashes. These he stored in his roomy attic. Thanksgiving approached. We went with him to look them over. He stroked the shining surface of a special beauty and confided to us that he simply hated to have it eaten.

Even those young barbarians, boys in their early teens, show unexpected streaks of sentiment. This surprised the teacher of what was probably the first school-gardening experiment carried on in the rush of a big eastern city. Here on an exposed corner lot forty boys of the hobbledehoy age, for the most part tenement born and bred, staked out their garden. The rougher the work the better it pleased them. For, like all young creatures, they loved to push and pull and stretch. The mere exercise they enjoyed to the utmost. Perhaps the reason was that in spite of promises they did 
not really believe that lessons could produce eatables. It seemed to them, no doubt, as it did to some of the teachers across the way, not exactly suitable that school should stoop to bother with vegetables.

A month flew by. The red-letter day arrived, and the early radishes were big enough to pull up. How superb those radishes looked! The topknot of green set off the most brilliant of surfaces, which, by the way, had been polished to the last degree by the skillful action of a coat sleeve. "And then," you ask, "did the hungry urchins fall to and eat them up ?" Far from it; the garden brigade marched home that day, stiff as drum majors, each man of them decorated with a radish in his buttonhole.

In the seasons that followed, hundreds of radishes and other "garden sass" in great variety was harvested from school and home gardens by scores of boys and girls. And during these years many unexpected traits of character cropped out. But this particular note in boy nature, - sentiment withstanding appetite, - struck so entirely by chance, never rang out more clearly than at this moment.

With incidents of this sort in mind it seems quite possible, through gardens, to train children in beauty and order. The kind of order, however, that children are most likely to appreciate is not that expressed by trim beds and straight rows, although in time they learn to care for neat and precise effects.

It is the larger, the more universal evidences of order that appeal to children earliest. Even little children are impressed by the orderly march of the seasons and by the glimpses they get of the laws that govern living things. This is shown by the very questions which they ask, in all simplicity, of us grown-ups. And how we hesitate and stammer and blunder at the ordeal of answering; it looks sometimes as though we 
had almost forgotten how to wonder. Not out of a book but out of a garden children learn that

... the world was built in order,

And the atoms march in tune;

Rhyme the pipe, and Time the warder,

The sun obeys them and the moon.

It is a fact that children respond enthusiastically to those mysterious forces which surround them, and which they must gradually learn in a measure to control. It is next to impossible for a child to work a whole summer in his garden without unconsciously tuning himself to certain universal laws. While he is grubbing in the earth, stirring the soil untiringly so as to let in the moisture and the air, nature's secrets are sinking deep into his heart. And there they abide, living springs, ready to bubble up and to sweeten and purify his whole life.

New wonders are waiting for him each morning : to-day he is excited over the upspringing of his first onion seedling; to-morrow he proudly views a patch of corn; soon his own plants are towering above his head. He sees how gracefully they can bend before the wind just because they are so stoutly buttressed with special roots against sudden storms. He sees how each stalk by its presence helps all the others to stand erect. He sees how each organ of each single plant has gradually adapted itself with marvelous niceiy to serve the whole organism. He finds all sorts of curious things to wonder about. $\mathrm{He}$ wonders at the clever packing away, within a seed, of rations enough to start a plantlet on its life march, and thus he gets an idea of the provision made for all the new babies of the world: He wonders how the soil can make over every atom that is unsavory or unclean, an apple core or a bruised butterfly, to the purposes of order and beauty. Surely one of the finest uses of a garden is to reveal Mother Earth to children. 
Fathers and mothers are the ones who appreciate what gardens do for children. They deplore the flabby, dependent attitude of young folks toward tasks, whether these have been set at home or at school. To be sure, they do not express this in educational "lingo," but they say, "Our children have no gumption," or, "They are so indifferent and blasé." Parents grumble at the schools, -- who could help it ? But they finally acknowledge that school is not wholly to blame, and that really the general aimlessness of boys and girls is one of the inevitable evils of town life. Men and women of country stock themselves, perhaps, remembering the zest of their own childhood, with its wholesome duties and simple pleasures, are perplexed over the folly of chaining up a child on the one hand or letting him loose in the city streets on the other. They try to remedy the difficulty in various ways. The father of a handful of growing boys, when this problem forced itself upon him, deliberately transferred his business from the city to a country town in Massachusetts, where he bought a small farm and raised chiefly his family. He knew he must pay in a multitude of ways for this luxury; but he has got in return vigorous lads, in whom there has developed conspicuously the rare stuff called leadership. Again, a man occupying an important public office tells us that the year before his family moved into the country the doctor's bills amounted to five hundred dollars. In the five years since, he has paid, all told, just six dollars.

Parents who cannot move out of the city have tried to compromise by sending their children to some out-of-town day school or, at stated intervals, to some teacher of gardening in the suburbs. A successful instructor ${ }^{1}$ has taught a number of such pupils. One mother has accompanied her little I In Watertown, Massachusetts. 


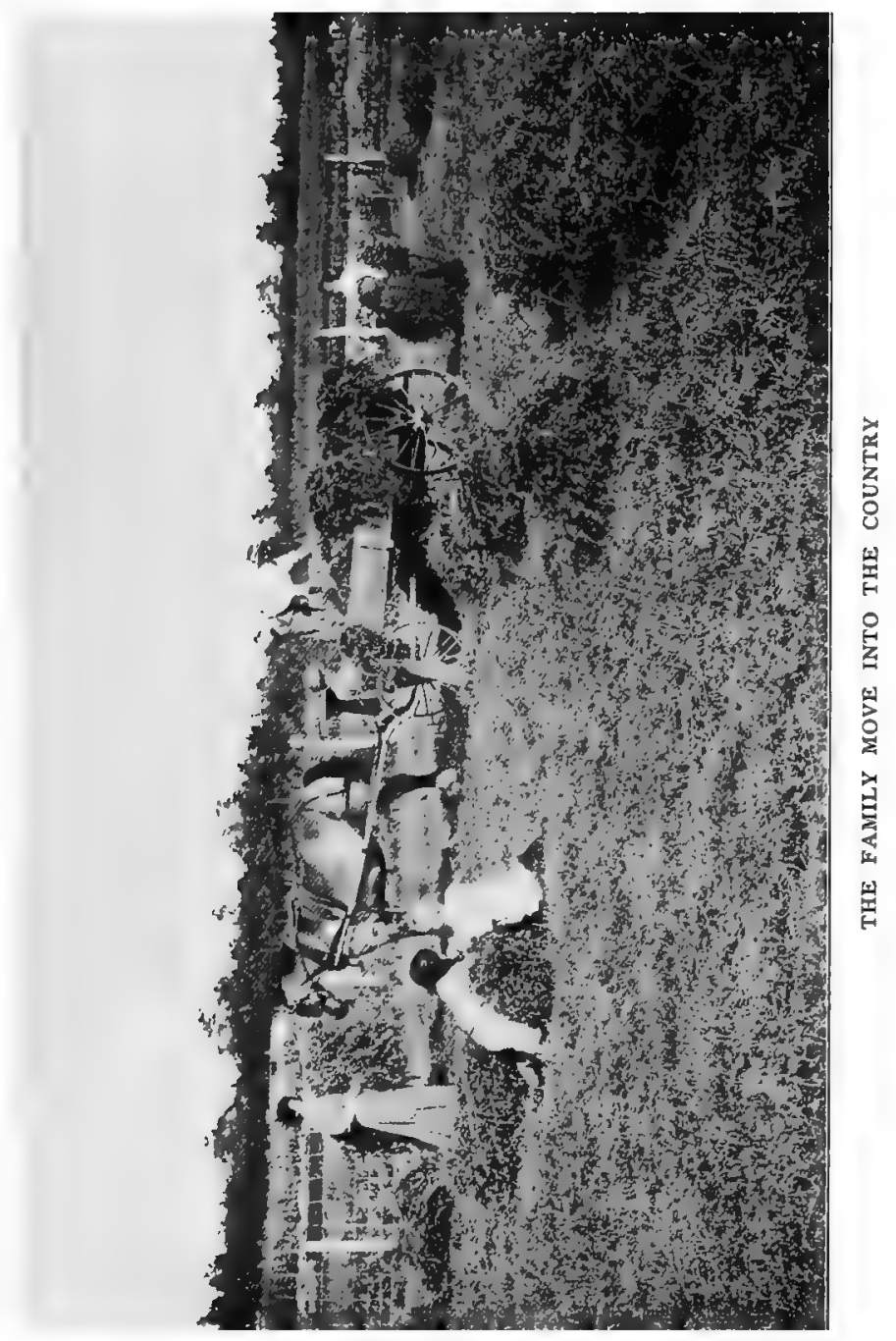


daughter 'of nine to an out-of-town garden every Saturday morning for two seasons. They have been learning together how to garden.

Appreciation of country life for children is, however, not confined to the ranks of the well-to-do. Those who are tied to a job through an eight- or nine-hour working day are also willing to make sacrifices for the sake of this idea. The wider one's experience the firmer one's belief that gardens have no stronger advocates than the plain people.

An incident is worth telling here. In the throng at a recent horticultural show of children's gardens two visitors attracted the writer's attention, - Veronica (a small colored girl, aged twelve) and her mother. Evidently they had come for a purpose. They inspected the prize tables, lingering a long time at each. Every now and then Veronica would write in her scrap of a notebook. An acquaintance was soon struck up.

It appeared that the exhibit was to be used as the subject of a school composition; the children having been permitted to choose their own theme. But why this particular one? Thereupon hung a story. They lived in a South End tenement; the mother did cleaning. Her regular places were mostly offices in buildings down town, but on Saturdays she scrubbed for a private family ten miles out. This was because she could take Veronica along, who was allowed to work in the garden with the children of the family. The mother after some coaxing explained why she considered the triple sacrifice of time, strength, and money worth making, expressing in the vernacular of a working woman the fervor of a Pestalozzi.

So far we have spoken of the value of gardens to individual children with little reference to the stimulus of companionship. But in stopping here we should lose sight of a tremendous force, - the drawing of kindred natures together for the better accomplishment of some distinct end. 
The social life of a whole family may easily center around the garden. A young girl living in one of the few remaining dwelling houses now standing in the business section of a city tells a charming story of their home garden. It slipped out quite casually one day in the botany class, through an endeavor to persuade her classmates to plant flowers on their roofs. To show how well this would work, she drew a little picture of their own family life.

There were nine children. The father had always gone daft over his flower garden, and the children were worthy scions; but bit by bit the land around them was sliced away and nearly all the sun was shut out by high buildings. At last they agreed to transfer their garden to the shed roof. So the neighborhood was scoured for boxes six feet or more in length. Then took place the exciting ceremony of hoisting these boxes up onto the roof. The best arrangement for them had already been discussed. In readiness for planting they had contrived to raise seedlings and slips by putting them under the skylight — the only place where the sun could stream in. These boxes of plantlets the children would run upstairs several times a day to adjust so that the rays should always strike just right. It was plain to see that, besides the joy of the work itself, this garden, like many another, gave opportunity for the interplay between young minds and old, and on more or less equal terms. Such opportunities, if we stop to think, occur too seldom, particularly in these days when interests, and especially pleasures, are so largely stratified according to age. It is self-evident that the girl in this particular botany class, who owned a garden, would have a much more solid foundation for knowledge than the rest, who had learned their facts from mere detached schoolroom specimens, no matter how carefully these might have been selected for them by a teacher. 
Primarily, of course, a garden is beloved for its own sake. There are occasions, however, when it is chosen as a background against which to group other plans. That it can serve in a sense as a theater for human play only brings out a new value.

A real little drama was recently watched by a young college woman who lives in the Jewish quarter of a seaboard city. One June day two lads (neighbors, but almost strangers to her), having spied some young children gardening with their teacher in a distant part of the park, rang her doorbell and asked if they might not use her back yard for a garden. Neither of them, it appeared, had ever had a garden; but they wanted, so they said, to raise potatoes. At last she consented, and operations began.

The spot, as she described it, was hardly one to tempt a gardener. The yard was brick-paved, and the sunshine, oh, so scanty! With the assistance, however, of a number of willing-handed friends, who at the right moment appeared as by magic on the scene, they began filling it layer upon layer with earth, which they brought mysteriously in strawberry boxes and paper bags. Where this came from nobody inquired, until one day a being in policeman's buttons rang the doorbell and called attention to the fact that her young friends had been scraping soil from around the shade trees in the Mall. The affair, he seemed to think, had gone quite far enough; and yet, with characteristic softening of mood, he gave her to understand that in one special comer there was an earth heap which the boys might draw upon so long as they dug at certain hours when duty would not compel him to interfere. So, suggestive of ants rather than lads, they continued carrying the earth until it was spread evenly over the plot, at least a foot in depth. Next they brought potatoes from their home kitchens, cut them into quarters, and planted 
them quite - if you please - according to orthodox rules. Where they had learned this still remains a mystery.

All through the long summer's heat this little band raked and watered and weeded, in fact fairly brooded over the rows of potato plants. These in time actually looked quite flourishing, and were extravagantly admired by many child visitors. But, sad to say, the season ended before they had produced a single potato large enough to cook.

Here the tale might be expected to end. But no, the boys were not vanquished by what an ordinary critic would have called a wasted summer. The following spring found them once more at their neighbor's door, with even more earnest pleadings, if possible, than before. In the meantime, however, fresh difficulties had arisen in the shape of a new landlord who did not want to bother about boys. And so the lads went their ways. Whatever the incident had meant to them, it was not without its value to her, and she would not dismiss it without inquiring into it carefully. The movement, it seems, had owed its impulse and its execution chiefly to one boy, a born organizer. Gardening had somehow struck his fancy; he saw in it the very magnet with which to attract his "gang." Through his gift of leadership this arduous work had prospered, and of course the reason that it did not strike the children as a failure was that potatoes was only the opportunity for association, not the underlying purpose.

No one who understood children could help sympathizing with the latent possibilities of such a situation. Tempting fields for mischief lay all about them - beckoned to them, in fact, from every alleyway. Yet they had chosen this area, which, though tiny, in its possibilities was vast. Far more remarkable than potatoes, there had flourished here a faith in cause and comrades which, in no mere figurative sense, could remove mountains. Faith like this forms the basis of 
all coöperative work. What this particular situation needed, and needed sorely of course, was a wise word of advice slipped in by the right grown person at just the right moment to reënforce the children's own effort. If only this had been forthcoming, the tale might well deserve to go on record as a splendid example of how a garden may educate children through utilizing spontaneous desires, and, incidentally, how it may give trend to their life interests.

But imperfect as this experiment was, in so far as these youngsters had united in working out plans of their own they were getting positive benefit; they were, besides, reading the romance of growing things, and they were being disciplined in self-mastery and initiative, the possession of which determines whether a person is effective in life or not.

These glimpses of children's doings bring into clearer view many activities that are going on all around us every day. If the three most significant of these activities were to be pointed out, one would be the training of producers, another the awakening of interest in nature's laws, and the third not the least in importance - the joyous companionship shown in planning and in working out plans. Each of these activities has gone on, it must be remembered, quite outside the realm of a formal school or a certificated teacher. ITe become possessed by the thought of what a garden might accomplish in a school dealing frankly with living issues and guided by teachers willing to lend themselves to its rare possibilities. 


\section{CHAPTER I}

\section{WHAT MAKES A SCHOOL GARDEN WORTH WHILE}

For Weakness in freedom grows stronger than Strength with a chain.

SIDNEY LANIER

A garden carried on in a home where desires and delights are companions, not foes, seems the most natural thing in the world. This is because the knowledge that springs from the joy of such gardening is in its very essence real. But it requires a good stretch of the imagination to set this cherished pursuit fittingly in a sharply defined course of study. To tell the truth, it has never been taken quite seriously; and while excellent starts have been made and many have entered for the race, nobody has as yet reached the goal. This goal in children's gardening is the secret of making it yield to a school program its entire and unique contribution.

Nobody will, of course, deny that the garden has been cordially welcomed as a pleasant accompaniment to various educational projects. It offers, for instance, a kind of supplementary manual training, besides a large and varied supply of material for nature.study. It is also, as we know, a powerful magnet to attract children from the street. Notwithstanding these recommendations, it has not, so far, on its own account rendered a sufficiently distinct service to save it from the odium of being classed with those last straws which a patient curriculum is obliged to bear. The simple fact that the sacred hours of schooltime are dealt out to gardening so grudgingly, if at all, shows that it is still a sort of annex to the school instead of an integral part of it. 
If, however, gardening must at present be judged on its incidental merits, there is one of these, as yet unmentioned, quite worthy of leading all the rest. It is the subtle, sunny influence of gardening which has mellowed the atmosphere of many a schoolroom. Garden teachers themselves are the first to realize this. "Whatever else," begged one director of her associates, "do not make the garden into a schoolroom, but make the schoolroom more like a garden." Putting this plea into words would hardly seem necessary; for to carry the formal and repressive customs of some very good schools out into the exhilarating life of the open would be as impossible as to carry the powdered wigs and low curtsies of the minuet into a game of basket ball. A whiff of the spicy air and the call of the warm Mother Earth are in themselves enough to snap the ties of formality between teacher and children; and it very soon happens that in spite of itself, the hand of the disciplinarian relaxes its rigid grasp and gives rein to elasticity, buoyancy, and good comradeship. In an atmosphere charged with these life-giving qualities there is developed, out in the garden, an easy give-and-take in opinion, a cordial comparison of results, and a respect for the efforts of others and for their possessions such as never was known indoors.

The value of having workmates as well as playmates is something that very early appeals to children; it seems to them only good sense to make common cause with others. In gardening they must organize, at any rate, for mutual defense against foes, whether two-footed or four-footed. This may be done so effectively that in a school garden there is seldom any trouble from intruders. As a matter of fact, there are no more efficient guardians of property anywhere to be found than the children themselves. To put it in barbaric terms, they have learned once for all through these 
experiences that "the strength of the Pack is the Wolf, and the strength of the Wolf is the Pack." This fierce phrase contains the germ of mutual aid; and mutual aid can by the right culture be nurtured into coöperation; and coöperation is to-day the great life force of society.

Now, admitting that all these dynamic currents are being set free in a school garden for the purposes of education, the question is how they may be most effectively employed; and this can hardly be profitably discussed until the use of the term "school garden" has been agreed upon. By some it has been interpreted thus: A school garden worth the name is not a teacher's garden, or a philanthropist's garden, but a garden worked out in thought and act by happy, purposeful children. "Purposeful," in the mind of the educator, would naturally mean that the children, as well as doing the work, are carrying out plans of their own devising. Is this too much to ask in behalf of an education garden, if that is what it really is to be? Hardly, if we are considering the garden from the viewpoint of the child; but considering it; for a moment, from the angle of the teacher, the emphasis somehow changes. That there is a difference can easily be explained by the fact that to a teacher the garden plot, in and for itself, is often the matter of deepest concern. And, as it happens, more seems to depend upon the correctness of the early steps in conventional gardening than in any other study. Is a teacher so dull as not to foresee that, after the season is well under way, a mistake may be patched up, to be sure, but never really rectified? Even before midsummer a garden has become a sort of exercise book where each blot and crooked letter stands magnified, - made so large, in fact, that literally he who runs may read. For from the first spade-thrust a garden lives in the public eye. The genial policeman, the bank president, the butcher's boy, all pay a school garden the 
compliment of dallying awhile at the fence. Not a single one who passes neglects to toss over a bit of good-humored advice. Then, too, the searchlight of criticism, directed first upon the proportion of the beds, shifts presently to the arrangement of vegetables and flowers, and brings out the grotesque effect of a few lonely cornstalks, as well as the upspringing -- overnight, one could swear — of a fine lot of weeds. No other school task, it would seem, could ever be so constantly on parade. Alive to all the cruel possibilities of the situation, acutely supersensitive to it, as often happens, the teacher resolves in self-defense that from the grown-up point of view there shall be nothing to regret. Clearly the way completely to safeguard the situation is to keep every decision firmly in his own hands, conscientiously mapping out each detail (doubtless by the midnight oil) and then indicating in advance what shall be planted, and when, and how, and where. Then later he calls in, if he likes, that well-meaning but sadly disturbing element, the children, who, do their worst, cannot now make a mess of it.

And yet while one gate is being so conscientiously guarded against the dangers of infant folly, a more dangerous because more subtle enemy complacently enters at the other; for this very position of perfect safety is threatened by its own peculiar enemy, too much safety. It is easy enough to explain. In proportion as they are being denied their freedom, the children are losing the precious chance of learning by their blunders. If this, by some educational flash light, could once be revealed to the teacher, so careful about many things, he would be the very first to see his mistake and to realize that such a garden was actually in its plan and purpose the teacher's, and only by courtesy the children's. It is an instance of how the most beautiful pool may have the most dangerous shallows. 
Teachers are not the only ones who, in this particular, misinterpret the garden movement. A piece of work recently done by a certain social betterment committee in a small Massachusetts town may, just here, add its own word to the discussion. It appears that the determination of these publicspirited people to carry on a vacation garden had unfortunately been made too late in the spring to connect properly with the public school of the vicinity, or to enable the leaders to make friends with the children. They, however, did their best. The events of that summer as they are described pass before us with the vividness of moving pictures. The opening day arrived, and with it tumbled in a troop of boys and girls bent on getting, in some form or other, an adequate return for their curiosity. The ample field, generously loaned for this project, lay before them; it had already been plowed and raked, and tidily divided off into sections. Next the ladies and gentlemen of the committee distributed the seeds, and, amid some confusion, gave excellent instruction upon the rules for planting. The exact places where the seeds were to go had already been decided, and these were explained by means of a carefully prepared map.

At the season's end a devoted member of this committee, very expert in horticulture but very inexpert in dealing with children, in almost these very words described the outcome of their summer of good works:

"Yes, the gardens themselves turned out well enough. We directors, of course, had to do a good deal of drudgery, such as weeding, ourselves. By watering thoroughly in the evenings my sister and I managed pretty well to keep things from drying up. But the children, I am sorry to say, were disorderly and ungrateful. I can't tell you what we went through. Excepting a few dear little girls who came regularly, not one of them seemed a bit interested. I never saw lazier boys. 
The most discouraging part was that after the vegetables were beginning to ripen, these same boys, so we think, would trample about after dark and pick things. Of course that was too demoralizing. We took turns at teaching them. This first year we could not afford to hire any one. Perhaps a regular teacher could have made them behave."

That this little tale was set in a minor key is probably due to various causes rather than to any single one. But certainly these excellent townspeople, like a good many of us when we set out to work for others without particularly consulting them, missed the point. Seemingly it had not crossed their minds that the only logical excuse for a vacation garden or any other sort of children's garden might be the development of the children, and that development comes through real activity in contrast to mere manual work or drudgery.

All this gives wide sweep for discussion. But how it is possible to conduct gardening at all in a school of several hundred children may well be considered now. For certainly not all grammar schools, even those in the outlying districts of towns, are so favorably situated as to allow garden space for every one of its grades. Yet in the face of serious obstacles some schools have been able to accomplish this, their success being chiefly due to the fact that the project has won the moral support of the community.

In this respect one of the most interesting schools in the country ${ }^{1}$ some years ago set apart garden space for all its grades. Each child, from the kindergarten up, tended a plot of his own, progressing in gardening very much as in his other studies. Moreover, a large proportion of the lessons indoors were based upon the lessons outside. All the school years of such a child, therefore, are vibrant with interest in the fields. Think how such an interest would permeate his life.

1 Whittier School, Hampton, Virginia. 
In some schools only one class each year is given the privilege of gardening; and in these cases it is generally the middle or high grades in a grammar school that are chosen. Yet the other classes often participate, in a measure, though they have no plot to work in. Here the younger children watch every event that affects the garden's prosperity, and regard it with quite a tremendous sense of its importance, as well as the importance of the superior beings at work there, whom they admire far more than they do their teachers. They hang over the fence, casting wistful glances and making sage comments. By the talk to and fro it is plain that they are looking forward with ill-concealed impatience to the year after next, it may be, when, by the rights of

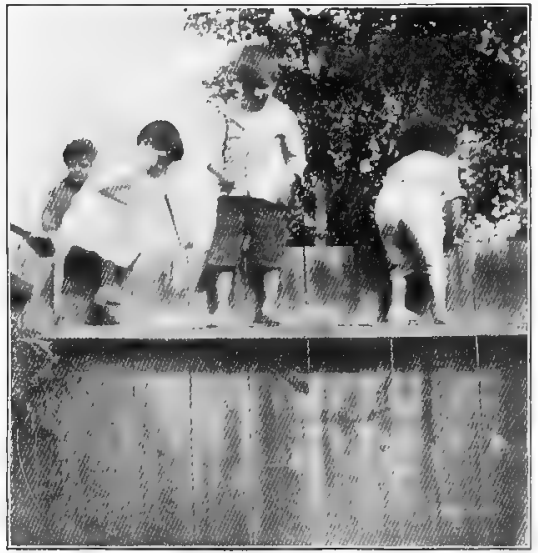

WATCHING BROTHER WORK succession, this honor will fall to them. Once in a whilehappy mortals - they may be invited in to help check a raid of potato beetles or to push a wheelbarrow.

On the other hand, the scholars who have passed into higher classes or out of the school altogether show in the schemes an elder-brother interest, strongly tinctured, it is true, with chaff and advice. But this does not seem to give offense, particularly if it is accompanied, as is the rule, by a willing hand at some critical moment. Many children prove the worth of their school course by undertaking more specialized or more ambitious work in their own back yards, and by 
bringing offerings of fruit and flowers for the whole school's admiration and enjoyment. The bonds of brotherhood in a school are further tightened by the lively exchange in suggestions and requests which goes on between those who belong to the garden class and the rest. The head class in commercial geography, for instance, sends a message that in a certain month it will need for its lessons samples of the different grains, or perhaps of cotton or tobacco, which it begs the gardeners to plant for their use.

It may seem that quite too much is being said about the activity of the children, and too little about the duties of the teacher. The teacher's part is indeed important, but it reminds one a little of the share sometimes taken by a "grown-up " in a chorus of children's voices. He may not audibly join in the song at all, until some harmony needs a deeper, richer note, quite beyond the range of a child, to fill out the chord. When this has been added, the music, by its very completeness, satisfies and thrills them all. And so it happens that oftentimes the part of the teacher is as inconspicuous as it is indispensable. A teacher who realizes this knows that the more nearly the school approaches, functionally, to the living organism, made up of organs, tissues, and cells, - each for all and all for each, - the greater pity it is for him to work it like a mechanical toy. The more wholesomely active all the members are, the sounder, of course, the organism. And so teachers are coming to believe that to deprive joungsters of the discipline of at least helping to map out a project is to do them a positive wrong.

Other teachers go still farther. They belicre in passing over to the children, come what may, the responsibility of working out the whole garden scheme. No situation, they urge, will present itself to a self-organized team of active, wide-awake girls and boys, occupied with problems of their own, that 
cannot be splendidly met and mastered by them. They have satisfied themselves that the very puzzles that elude the comprehension of the grown-up, and vex his soul, if honestly put to the children are courageously attacked and by some magic skill solved by them. To borrow a bit of philosophy, Children rush in and win where grown-ups fear to tread.

There is not the least doubt that a surprise is in store for those grown-ups who will in all sincerity try the experiment of consulting a band of children upon some matter that deeply concerns them. Indeed, why not consult them if we are training them for democracy? An answer to those who doubted the success of democracy was given awhile ago by Jane Addams. It was simply this, that the cure for the evils of democracy was more democracy. Why not try, then, as a cure for inconsequence and irresponsibility on the part of young people, about which there is so much complaint, more and more responsibility?

Of course the laying of responsibility upon children must not be undertaken lightly. To the teacher and the parent, how much and what responsibility it is best to give over seems destined to remain an unknown quantity. Perhaps a child's hunger for responsibility is like the hunger of a four-footed creature for food, - a reasonably safe indication of the demands of his system. If șo, there needs to be deliberately offered him a chance to take, quite voluntarily, some responsibility. Then, by an open-eyed and open-minded teacher, the experiment can be watched. No studies of children are more stimulating for the teacher than these; and no surroundings, as we have seen, are likely to be more favorable than a garden.

Society is never as simple as it looks, either in or out of school. A number of distinct types of child personality reveal themselves to a master who "lets go" in this way, for a little, 
and takes the risk of offering to his class the responsibility of sketching out beforehand, as well as actually handling, a year of gardening. These child types will vary according to natural tastes, temperament, and power of initiative. Not all young people, for example, will take hold of the gardening problem with anything like the same ability or enthusiasm. There will surely be a few who in their heart of hearts, though they may not seemingly hold back, are indifferent or actually bored. It is for a grown person to anticipate and deal with this attitude without any regrets or coaxings. A good way is to substitute without discussion some school work, of a more orthodox stamp, peculiarly suited to the needs of those who prefer reading or some similar task indoors. Freedom to take gardening or to leave it will, more than anything else, sharply test the genuineness of the situation, and prove conclusively that the occupation of those out in the field is truly voluntary. As experience shows, it almost inevitably happens that these indifferent ones will be drawn into the project by some real and happy interest which had to be awakened gradually. A large proportion of the class will probably, from the first moment, justify the optimism of a teacher by having a more or less definite aim, together with no small amount of efficiency and poise. Conspicuous among such children will be those who in just the right kind of home life have been intrusted with important errands, and have looked after the comfort and safety of younger brothers and sisters. These young folks may not be the ones who never trip in behavior or in a spelling test, but they prove themselves, nevertheless, to be miles ahead of any such little prigs in the ability to deal with real issues. These children are quick to suggest courses of action and to foresee those disasters which are ever descending out of a clear sky upon the inexperienced and improvident. They grasp with all speed the idea of adjusting themselves 
to new and unexpected conditions. These are the earliest signs of leadership.

By what has already been said, the art of the teacher is seen to be distinctly constructive. Just here he will study to give as naturally as possible, not merely to a select few but to each young human being, such opportunities as are needed to develop him out of a state of self-centered dependence into one of freedom and fullest usefulness. To see that this happens requires no small amount of insight and discretion. Some pupils will need to be shaken out of their self-importance. A "bossy" child, for instance, is usually disciplined by his coworkers. Others, on the contrary, will be found lacking in initiative and limp except while spurred by the persistent vigilance of an older person and stimulated by the hope of conventional reward.

Garden work will, perhaps, in this way offer the golden moment in which to break the fetters of an artificial school life, for a true education garden can be managed so that the child faces the conditions of the real world. A stern, uncompromising world to wrestle with it is indeed, but by good luck he may face it with the supreme advantage of a clear-sighted, yes, and devoted, friend by his side - the teacher - and with an organized brotherhood of fellow workers, who will make his success or his failure theirs.

Let us consider for a moment a few of the special uses in life to which the power of initiative can be put, and how it can be further exercised in a garden. One thing is plain : if any of us could rely upon traveling "personally conducted" through life, the power to blaze new trails would be unnecessary. But each day's problem comes to every individual man afresh, however humdrum or circumscribed his life. Sometimes it is the old one with new variations, and sometimes it is a brand-new one. Is there any recipe for attacking a 
brand-new problem? And can gardening give us practice that will make us more successful in doing it? Granted that it 'can, let us first ask, What is the method of approach? A sort of preliminary skirmishing discloses, in any new undertaking, so much that we never dreamed of at the beginning, - and how little any one person really knows, after all! The horizon widens every minute, delightfully but oh! so inconveniently. We find ourselves launched upon a pond that has suddenly widened out into a sea. The great pulsating world of action gives everywhere the same answer to our question: Investigate; study first what others have successfully done, and try to find out what direction improvements are taking. Any great project of scientific or commercial importance, for instance, illustrates this on a huge scale. Inquiry into enterprises of this sort shows that men are dispatched east and west to get in touch with the very latest aspects of the question. Dashing ahead without a notion of what older countries have already adopted, or perhaps have tried and long ago discarded, is a trait that in the past, perhaps not altogether unfairly, has been said to belong to Americans.

Dashing ahead has, in truth, never been a fault of agriculturists. And yet if investigation and general enlargement of views are important for any body of workers, they are supremely necessary for the farmer. It is so easy to be swamped by details and to settle down into the "good old ways." One does not need to look twice to see how agriculture, led by science, is advancing by leaps and bounds away from the region of guesswork to that of solid fact. Never before have the scientific and the practical gone hand in hand as intimately as they do to-day. The future holds out rich promise to those who will fraternally unite to get the best production combined with the most effective distribution. The ambitious gardener 
does not merely fall into line. He must lead; he must control the situation; he must coöperate.

Having seen what the world demands, we must prepare children to meet it. Yet how is it possible for mere school children, for instance, to investigate? One way is by studying some model farm. The model farm not only provokes inquiry, but sets standards and fires the imagination. Such a farm can surely be found not too far from home. Nothing kindles the enthusiasm of young students so much as a visit to one of these industries. Not a thing will escape their notice. Let them, if possible, come face to face with the very men who through initiative and the genius of hard work have reached the top of this industry and have dignified their occupation. Incidental results of greatest importance have also been accomplished by such a visit. It certainly quickens a youngster's ambition, and it dignifies in his mind the occupation of farming.

Let us then accompany a class in gardening through the chief events of the year and see in how many ways their real activities are aroused. Since collecting evidence takes time, and experimenting is slow work, the preliminary visit of investigation should be made in the autumn. Other visits will follow, in turn, to truck farms, greenhouses, and markets. By this time children will fairly bubble over with schemes of their own, which will luckily have all winter in which to simmer down. There are plenty of outlets, however, for surplus energy. Some of it may profitably be turned toward making a map of their own land to scale. Then they will ransack the local libraries for books on agriculture, and collect pictures and catalogues. Seeds have to be ordered early. Some children will become interested in learning how to test them ; and they can show the others. Those wondrous fruits and flowers portrayed in the seedsmen's catalogues bewitch children no less 
than their elders, so that they will make at first ridiculously elaborate planting lists. But common sense, combined with the restrictions of pocket money, very soon reduces the items to a list of reasonable length. In short, there is so much to do that the children will be busy every day painting in vivid colors a garden in Spain which is. destined, in part at least, to come true.

To go from fancy to fact will be a great relief; and so all are radiant when in the late winter indoor planting can really begin and go steadily ahead. The seeds will be started in the house; the young plants will be transplanted, first to a frame, then later to open beds. Much interest will center around the plan of growing the same sort of plants under widely varying conditions. These will be valuable experiences and will reveal interesting truths.

As the weeks fly by, happy surprises await everybody. New possibilities occur to the children thick and fast. Many boys and girls will have drawn their families and all their relations - their whole social circle, in fact - into this whirlpool of interest. The father of one girl turns out to be an importer of bulbs; the uncle of another lends his camera. From the north end of the town arrives, some fine day, a package of seeds, which all share with glee; from the south side comes a carpenter's offering of boards for a cold frame. Current numbers of outdoor magazines will be brought, and certain members, on request, will read aloud to the others bits of garden lore which no farmer can afford to miss. Each young student catches the spirit of contributing something, no matter how little, for all to enjoy.

The ways of working out plans are bound to differ. Some people prefer to devise and perfect by themselves a scheme which will burst upon the others in all its final magnificence; others discover that a bit of work gains in scope and effect 
through combination with others. Of course in these exercises the tiresome school etiquette of "no communication" will

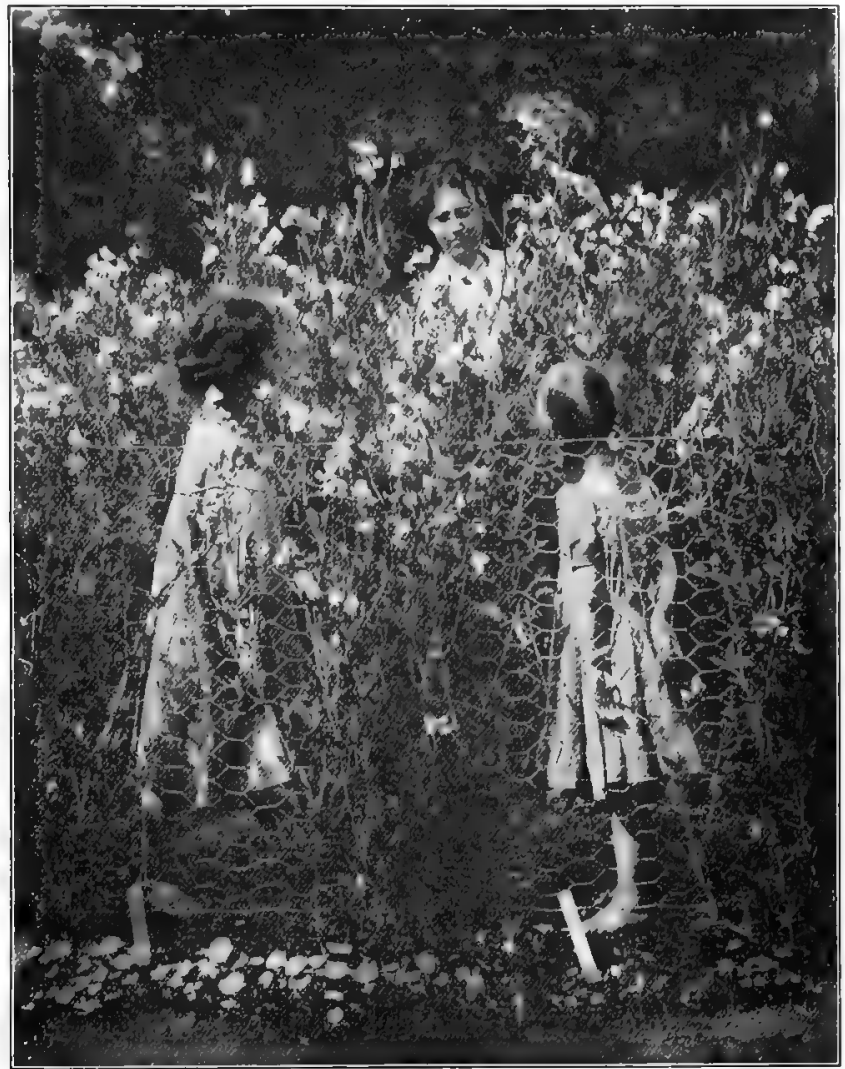

FROM FANCY TO FACT

have to be replaced by just as much communication as possible. But in the ordinary school special arrangements must be made for consultation. Every moment becomes so precious to the children that they insist on its being put to the 
best account; consequently, there is no "fooling." A new sort of vitality leavens the whole school. If one word could express this, it would be the word "together." It marks the beginning of conscious coöperation which all the restless children of the world are calling for.

But now to the garden. It is April, the long-looked-for month for outdoor planting. Before this the plan of the school garden will have been finally accepted by the class. This is, of course, a composite plan. It is made up of contributions from everybody. Only the inner circle will ever know how many offerings, how many sacrifices of personal preference, will have been made for the good of the whole. Even the pedagogue's secret fears of how the garden will strike a critical public have at last been set at rest. For great pains is usually taken by the children to secure an attractive appearance, although, it must be admitted, tastes differ ; and taste at thirteen is not taste at thirty. Suppose, as sometimes happens, the children set their hearts on a fantastic shell border or rockery or arbor, the mention of which is enough to make some teachers' blood run cold, for of all things a teacher cannot bear to be thought crude. But what of it? The essentials of a good garden are not affected; so why cheat the world of one atom of the delicious spice of child life? Moreover this desire may mark a distinct stage in the children's development. If so, may they not better pass through that stage and satisfy the longing while yet children, than wait to grow up and.inflict upon the world what. may be called millionaire monstrosities?

As a result of some such management as has been pictured, teachers have learned that with assistance, but no interference, a tidy kitchen garden, bordered by some pretty color effects in flowers, may be confidently expected, and that no one need be alarmed if it should be emphasized, here and there, by some 
original departures which will contribute variety and possibly amusement. Yet whatever the garden may have lost in formality, it has infinitely gained in intrinsic interest from the point of view of any friend of children.

A.s the summer advances there is always less deliberate planning and more manual work. But handicraft and nothing else is, of course, the work of a mere laborer, and spading and hoeing are not and never will be of themselves inspiring occupations; so the garden is in danger of losing its highest value unless it can feed curiosity and awaken an appetite for investigation. A question met by an experiment, a doubt met with a demonstration, - this is ever how men have been learning from nature. Moreover, what they have thus really learned they want to tell. What greater incentive, indeed, can a student have than the opportunity of convincing his classmates of some fact that he has been working out experimentally? Having at last got his answer, he almost bursts with a desire to share it. Sometimes it will happen that several will combine to present proofs for convincing the rest. Again, the whole class will form a team in order to make a bit of investigation, each one doing his part toward a successful issue.

This brings us to the most effective way of operating the gardeners' forces. There has been much discussion as to whether a garden is best worked in common or divided into individual beds. Separate ownership of the various plots, as opposed to general or communal ownership, has many advocates. Certain it is that the individual plot fosters the feeling of proprietorship and personal responsibility; it crowns with more or less justice individual fidelity. It is indeed very wholesome for any young person to gaze upon his own mistakes and triumphs writ large, - spread out in plain terms of weeds or fruit. Many eloquent lessons can thus be driven home without a single comment. But disputes and jealousies 
have been known to flourish, too. In one well-managed garden it is the custom to "choose partners" for the working of each plot. This is certainly a step, if not a stride, toward coöperation.

Probably the ideal way to utilize the highest incentives and bring out the best in human nature is through harmonious little partnerships working within one great brotherhood. How rare it is for grown people like ourselves to do their most telling work in isolation! And is it not true that some highly
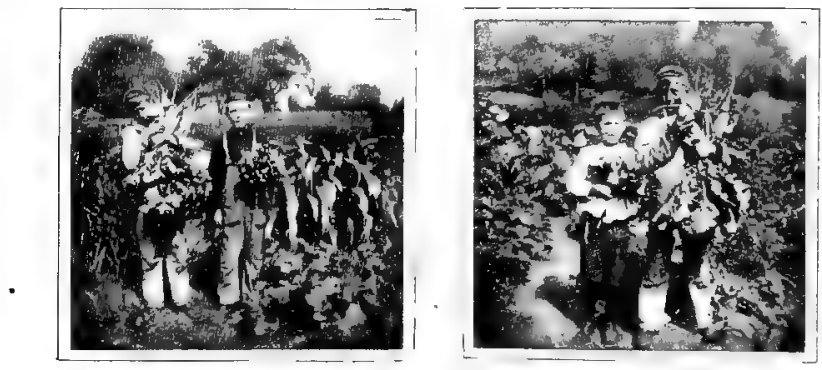

PARTNERS

gifted and efficient persons are pitifully limited in their usefulness just because they cannot work with others? Each one of us has learned, with more or less success, to reënforce his own peculiar gifts by the aid of criticism from efficient and responsive friends. The habit - one may truly say the talent - of working with others has been somehow supposed to develop of itself. The recognition of this talent as a force to be nurtured and utilized during the period of school life has, some believe, been too long neglected. It is time for schoolmen to realize its deep significance.

Let us listen for a moment to what is being said by men out in the world who are "doing things." Not long ago the managers of certain important business enterprises were 
discussing the relative importance of traits which they positively required in their employees. With not a shade of disagreement they named what in their opinion were the three highest qualities, in the following order: loyalty, power of coöperation, efficiency. A schoolman who was within earshot began, with a Knowledge-is-Power air, to protest against this low rating of efficiency. But his academic argument was quickly swept off its feet. The reply flashed back that in real life efficiency, admirable though it is of course, has no positive value uncombined with loyalty and coöperation. And they would not yield an inch.

There is a long list of incidental values to be gained from a well-conducted garden. These may be reviewed quickly. It is, for instance, a great thing for a child to have learned to use intelligently the multitude of books, periodicals, newspapers, maps, tables, and reports bearing upon the business of up-to-date gardening. The vocabulary of a state statistician would not ordinarily fit the comprehension of an impulsive girl of fourteen. But if this girl has set her heart on getting for her friends certain information which they must have, rather than disappoint them she will make it her business to conquer a mere matter of words.

Under the pressure of such a purposeful atmosphere a dictionary has been known to rise many degrees in importance in less than twenty-four hours. From a mere article of schoolroom furniture it can become a highly valued friend. Furthermore, respect for the producer, for the scholar, for any one who foregoes his own ease to add one little grain to the sum of human welfare, results from even a tiny bit of real investigation done by a child, of whatever age.

The garden teacher, meanwhile, has been brought into surprisingly direct and human relations with the lives of his young people and with the problems of the community. The 
quality of the radishes at breakfast, and of the cabbage and onions at dinner, is graciously associated with a teacher's personality; and an introduction to the home circle as "Sammy's garden teacher," accompanied invariably with a flourish, guarantees a warm welcome.

Association with the daily food leads to other confidences and intimacies, nobody can exactly explain how. Such participation in the family life of the neighborhood becomes a source of deepest satisfaction to a teacher; and these friendships are real because they are mutual. Best of all, the community comes into its own by coöperating with the schools through a movement whose purposes it comprehends, and to the prosperity of which it can substantially contribute.

A vegetable and flower show displaying the produce of a season, attractively set out for the inspection of the neighborhood, may easily become the event of the school year. Many a plain citizen, who has long hardened his heart against other pleadings, will be enticed to such a festival. Such a person may turn out to be the first to appreciate " education by actualities," to promote among the young folks gardening as an occupation. There is certainly foundation for believing that school and home gardening is opening up to young people, especially to girls, an excellent means of livelihood. Women specialists in gardening assure us that although it demands hard work and business methods, it is attractive, it is health-giving, and it pays. What a school garden does toward such an end is to enlarge the arch of experience through which one's life work may be seen.

Whether the value of a school garden is viewed from the angle of useful knowledge, or from the angle of the scientific spirit, or from the still wider viewpoint of practice in the art of living, it is warranted to be worth while. But its greatest lessons, after all, we believe, will be lessons in the art of living. 


\section{CHAPTER II}

\section{LITTLE STUDIES IN COÖPERATION}

The hunger for brotherhood is at the bottom of the unrest of the modern civilized world. - GEORGE FREDERICK WATTS

In the labyrinth of garden possibilities through which we have been threading our way, two have been constantly attracting our attention: training in science and training in coöperation. Suppose we were accused of setting upon these too high a value. This charge might be made in all sincerity; and it might be admitted, too, provided our attention were riveted upon school problems alone and not upon world problems. But out in the world both science and coöperation play leading rôles in each day's business, great and small. The rôle of science is to develop the type of mind which in its humdrum aspect can turn its attention to inhibiting snap judgments or to sterilizing the baby's milk, but which can, nevertheless, perform equally well the supreme service of discovering the typhoid germ.

Coöperation renders its peculiar service by developing leadership and initiative, - not initiative in school sports and school debates alone, but initiative that makes the worker forge ahead in studies that connect with the larger if not the more real world of civic activity and household economics. Said the child, struggling to define salt, "It's the stuff that when it is n't in things makes them taste bad." Likewise of coöperation it may be said that, when it is n't in things, they go, oh! so badly. This, of course, is simply because we do not see what the other fellow is driving at. 
Active coöperative association permits rare intimacy with other souls, so that coöperation may be said to be a great revealer of character. Scarcely an emergency in life arises where a just estimate of human nature is not acutely needed. Even in the sporting world it does not come amiss, judging by that delicious bit of dialogue between young Nathaniel Shaler and the village character, who, it will be remembered, invariably got licked. ${ }^{1}$

"Sam, you ought to quit fighting; you are n't good at it." "My boy," said he, "I am the best fighter in this here county, but I ain't good at judging men."

The point need not be argued further. that science and coöperation go far toward making the sल! men and women the world wants. If this is true, then $t_{\mu 1}$ school world must in time adequately educate in these two directions. The cause of science has already many champions; and yet the very ones who are hot for science training in the schools are sometimes lukewarm in the matter of training for coopperation. In the course of one short discussion on school management all sorts of conflicting opinions may be heard. One person sticks to it that school life should be and is competitive, while another contends that the present-day schoolroom is in essence not competitive. And then the talk wanders from the point, till some speaker feels obliged to proclaim that in many a school harmony reigns, that noble and generous personal traits are fostered, and that truth, courtesy, and love for knowledge are daily held up by devoted teachers to docile pupils. Not for a moment can this be doubted. The Pied Piper may never so successfully charm his young flock into following him through the flowery fields of learning, and yet in all the measures they tread there may not be one coöperative step. They advance, to be sure, but without getting any dicipline in 1 "The Autobiography of Nathaniel Southgate Shaler." 
leadership or in loyalty to leaders. A person is a born leader just as truly as he is a born teacher, doctor, or actor, no more and no less. To work in the highest sense coöperatively one must be trained. Since we so glibly say that we are educating children for life, a timely question arises, Are we educating them for the coöperative or for the competitive life? and, putting aside any reasons we may have for pursuing one or the other of these two courses, should we not in justice to society be consistent?

On scrutinizing the beautiful fabric of life in the schoolroom, do we not discover, running through it, many ugly competitive threads? Look, for instance, at the whole system of school prizes, - these still exist, even though they masquerade under variertis names. There are competitive examinations, rank lists, graded seating, promotions, and marks, for marks are ever with us. Competition, we may conclude, is, on the whole, antisocial. The boy or girl, a social creature by nature, is through the arts of the schoolroom molded into the "model scholar." Perhaps his most conspicuous trait hinges on habitually minding his own business.

"Don't you find kindergarten children inclined to be restless ?" said a visitor to a sour-looking primary teacher, whose class had been sitting all too long in the "first position."

"Only the first day or two, for I mold them - mold them," she answered.

The Procrustean methods formerly used in such transformations are by a very short span of years removed from our own day. President Briggs, ${ }^{1}$ for example, reminds us that in his own school days "the boy who turned his head round to the boy behind had to stand on the platform with a spring clothespin on his nose till he saw another boy turn his head and transferred the clothespin to him."

' Le Baron Briggs, School, College, and Character. 
The Lend-a-Hand motto has proved an inspiring guide for life at home and out in the world; but is it a suitable or safe motto for the routine of the grade school? Or would it be necessary to slightly adapt it? Twist it, for instance, into something like this: "Look down, not up; look in, not out; and don't — as you value your rank - lend a hand." Yet however well this version might have suited the model scholar of the old days, it will not do for one of the new. Surely no coöperative fish could swim in such a sea of isolation.

Hundreds of teachers and parents would gladly banish most forms of competition that still haunt the schoolroom; but many of these very persons hesitate lest, deprived of incentive, a school might, like fatigued, flabby muscle, lose what is known as tonicity. Comparatively few seem to have considered whether, on the contrary, a school might not regain tone and even more vigorous health by adopting methods of coöperation. Some have not been afraid to try.

Stationed on the frontiers of the educational world on both sides of the Atlantic there are pioneer schools working on distinctly coöperative lines. In these the pith and core of a part, at least, of the instruction consists of practice in the art of coöperation, technically called self-organized group work. That the coopperative method in study is a life principle, and not a device to exploit certain pet subjects, is shown by the fact that its value is not limited to any selected studies. Whether it is applied to the dramatization of a fable in an English class by a group of six-year-olds, on the one hand, or to Roman history in a high school on the other, it works equally well.

As has already been hinted, a garden makes a most effective stage setting for the drama of coöperation. A very spirited comedy of this sort was recently enacted in a school for older girls. Here a class numbering seventy-five recently conducted 
a school garden as a part of their course in botany. This they did wholly themselves, although the advice of a teacher was always at their command. The girls organized, electing officers and forming committees. Then the garden was plotted, the soil prepared, the seeds sown, and the tools distributed and kept in order. Moreover, what was by far the most difficult problem, the program of work and the allotment of time were self-determined. The whole business was run with a more even and just distribution of labor, and with far more harmony and satisfaction, - no easy matter where so many were concerned, - than if their teacher had managed it. So at least admits the teacher. This test is certainly a fair one to apply. For if coöperation proposes to do the world's work better than individualism has done it, then it must do the work of the school better than individualism can do it. In the case just quoted, however, it should be explained that this was not by any means the girls' first experience in selforganized work, although it was their first attempt in coöperative gardening. Many difficulties in technic, therefore, had already been met and overcome.

The experiment proved quite worth undertaking, if only to show what practice does in developing team play in school work and among girls. The details are given by the girls themselves in the following report:

\section{REPORT OF THE GARDEN WORK OF SECTION FIVE 1}

The members of Section Five decided, in March, 1909, to assume the responsibility of the garden work; they agreed that it would require the best efforts of every girl in order to make the business a success.

The first matter to be decided upon was the selection of seeds. A committee of three members was elected; they elected a chairman who consulted with Miss W. as to the required seeds. It was found that every

1 Written by the Chairman of the Committee. 
section must plant the following vegetable seeds : beans, beets, lettuce, and radishes. There were ten kinds of flower seeds, however, from which four might be selected. The chairman of the seed committee embodied this in her report. The section voted for the following seeds: nasturtium, cosmos, sweet alyssum, and California poppy.

The committee visited various seed firms in the city and reported their discoveries to the class. Each girl contributed seven cents, for the agent had agreed to supply the needs of the section for a dollar and a quarter. The seeds were bought by weight, not by package; packages cost too much.

The committee, with the assistance of several other girls, divided the seeds among the eighteen girls of the section. It was, of course, a great deal of work; yet in the end it was more satisfactory. We found that seeds that came in packages were of a poorer quality than the seeds we used.

The section then elected a garden committee of three members and a tool committee of two members.

The first work of the garden committee was the measuring of the land. The land allotted to us was in two parts : one piece measured i 8 by 44 feet; the other piece measured 18 by 20 feet. The garden committee divided the first piece into 7 plots each 16 by 4 feet, allowing two feet for a path at the back of the garden, and allowing for two-foot paths between the plots. The second piece of land was divided into three plots 16 by 4 feet; one of these plots was used as an observation bed.

The girls chose partners. Each pair chose one of the plots, which they staked off with strings. Then they divided the plots into halves, each girl taking one half, 8 by 4 feet. The garden committee supervised the work, seeing that the strings were even, and verifying all the measurements.

The ground was broken in April. Each girl spaded, raked, and hoed her own garden. The ambitious ones sifted the soil; the others contented themselves with taking out the big stones. It was a long piece of work, but. the gardens were finally ready for the seeds.

The committee tried to arrange the seeds so that the effect would be harmonious when the flowers were in bloom. A given number of inches was allowed for each plant. There were two rows of lettuce and two rows of sweet alyssum. Of everything else there was one row. The girls measured off the number of inches required for each plant, and staked off each space with string. The committee supervised the work, seeing that the measurements agreed and that the strings were straight. 
The girls dug trenches for the seeds ; they followed the strings in digging. A prepared chart gave them the necessary knowledge in regard to depth of planting.

After the seeds had been planted, most of the girls mulched and cultivated the beds. Every one was pleased with the rapid progress of those gardens.

Each girl took care of her own bed in regard to mulching, watering, weeding, etc. Each girl also took care of the path on the side of the garden nearest the school.

The tool committee took care of all the garden implements whenever the whole section worked together. When only two or three girls worked, each was held responsible for the tools which she used.

Simultaneously with the work on the individual beds, the work on the observation bed was carried on. The bed was spaded, raked, and hoed; the large stones were taken out, and the soil was sifted. We planned to plant tomatoes in half the bed, and devote the other half to experiments in mulching and depth of planting. Later we changed our plans. We planted half the bed with tomatoes and cabbages. The other half we planted with asters and geraniums. The chief benefit we derived from this bed was practice in transplanting; all the plants were transplanted into the observation bed, and the girls were able to watch their progress.

The garden committee supervised all the work on the individual beds. If any garden seemed to need care, its owner was notified at once. In the general work, such as straightening the paths, and work on the observation bed, the committee tried to apportion the work evenly, so that each girl should have an opportunity to do something for the section as a whole.

When school was about to close, each girl selected one week of vacation, in which she agreed to take care of the gardens of the section. Each girl, after visiting the gardens, sent a postal to Miss W. telling her of the work she had done during her visit. The plan worked very well; at the end of the vacation Section Five's plot was in very good condition.

The reason for the smoothness of the section's work was the fact that the girls were so united; on the whole they were very coöperative. Of course some had the interests of the class at heart in a greater degree than others; that is to be expected. But they all worked hard; and it was the harmonious working of the girls with their committees and Miss W. that made the work succeed, 
While scholars are growing in moral and intellectual vigor as they practice coöperation, the teacher gets insight into human nature, and wisdom for further guidance, through studying the play of coopperative forces. As has been more than once suggested, watching the formation of groups among students who have perfect freedom to combine as they please brings great returns. The youngsters of unlike dispositions and different intellectual and social gifts often seem peculiarly drawn to one another. And yet what the combinations are that will blend harmoniously cannot be predicted by the wisest. The reactions are as mysterious as those that take place in the chemical laboratory, where a tiny globule of crystal-clear fluid is dropped into a test tube containing a second colorless fluid, and lo ! a beautiful play of color. In the words of the butler in the play, "You never can tell, sir, you never can tell."

At the call of a school emergency it may happen that some scholar whose ability has always struck the schoolmaster as mediocre is all of a sudden voted by his classmates into a position of importance. The teacher's first impulse as natural as the breath he draws - is to interfere. Instead, however, he waits. As the game of life goes on, he is surprised to find that the judgment of this newly elected leader, however slow, is sound; his determination, firm. By the grace of some hidden force he is making good. Every comrade is standing by him. At the finish this boy's efficiency, hitherto unguessed by his teacher, has completely justified the confidence which "the fellows" placed in him. On the playground such revelations are common, but all too rare in school!

And yet it must ever be a matter for regret that so often the strength of a child's personality lies sleeping until school days are finished, — all too early, perhaps, - - and life takes him up. In the stress of life surely he is judged by his fellows. 
Is not the divining rod, if there is such a thing, usually held by one's peers, be they five years old or fifty? At any rate, students certainly make wonderful guesses, and they hit the mark at least as often as professors.

A grown person who watches and studies the personalities in a self-organized group of children arrives at certain conclusions. Such a group, intent on its own serious business, has no use for mere talk; nevertheless any member who can argue well and can win support for some precious plan is a real acquisition. Common sense, a gift which takes prizes out in the world, but which in the classroom scarcely gets honorable mention, here in the heat of action carries off many a blue ribbon; whereas the wage of the habitual "windbag" or lazybones is that he is not welcome in any group, and is forced to right-about-face or have a lonely time of it. The sting of being left out when "all the fellows" are carrying out "great old plans" hurts him more than the loss of fifty credits decreed by a spectacled teacher.

Fortunately, when a plan is being carried out at white heat, a place is usually found, even at the eleventh hour, for everybody who can contribute anything. At such a crisis a pupil who is backward at books, who stutters, - it may be out of sheer self-consciousness, - whose memory for dates and schoolbook phrases plays him mortifying tricks, whose indifference during recitations has soured into actual mischiefmaking, may suddenly find himself committed to a piece of real business that brings out the man in him.

One simple incident will drive this home. It happened one spring afternoon at the garden lesson. The dunce of a grammar school class - whose mind, poor chap, was scarcely normal - took his place as a real person among classmates who had hitherto totally ignored his existence. Eddie had learned, never mind in what stern 'school of life, the meaning 
of labor. The tasks in the garden had to be finished by sunset; a dozen shrubs were waiting to be set out, and there was much tidying up to do. The mercury stood in the eighties. The patience of the class had almost reached the exhaustion point, when this boy showed his mastery of spade and hoe. The others hallooed to him from plot to plot. He came running in answer, giving here advice, there encouragement, and to everybody some sort of lift. For once they were the children and he was the man. It felt good; his face, which habitually expressed vacancy and despondency, now radiated happiness; through the joy of service he had found himself. This lad could never have satisfactorily designed a vegetable garden; neither could he have correctly calculated the pounds of fertilizer needed for the experiment beds. Measured by such yardsticks he would probably always come short, but here he measured generously; he was a perfect fit. It is good for everybody sometimes to "just fit."

The teacher's sympathies, once having stretched to comprehend touching revelations of human nature such as this, can never contract again to precisely their former compass; and so he goes on enlarging through each new experience. Who can wonder that a teacher longs to provide in school the conditions under which such experiences are possible?

So far a special effort has been made to discuss the claims of gardening, and its methods of promoting science and cooperation, as viewed through the eyes of general education. An important question will be that of extending the gardening interests which have been aroused in school out into the farming world. The word that modern agriculture has to say to the boy or girl who is considering farming as a vocation or as an avocation remains to be heard. This will be discussed in a later chapter, The New Agriculture. The immediate question is where to find available spots suitable for school gardens. 


\section{CHAPTER III}

\section{SITUATION AND SOIL}

In the hands of man there are no unfertile soils. - P. KROPOTKIN

There has lately been a great awakening in regard to certain needs of children. This is shown by the suggestion that all the schools of a big city should be transferred to the suburbs. Think what it would mean if the hundreds of children now doubled over desks in dingy buildings could every day be conveyed to regions of sunny space, playgrounds, and gardens; yet so sharply does this proposition conflict with the ancient notion of a bookish education that it was at first taken as a joke. Before long it began to be seriously discussed. The idea is gaining ground, until now it may be considered as an actual promise for the future. There is in sight, too, a happy day when the garden will be called upon to take its place in the scheme of education and to fulfill its social and scientific possibilities.

These are certainly in no danger of being exaggerated. One educational leader ${ }^{1}$ does not hesitate to use these words : "The most workable living laboratory of any dimensions is the school garden. . . . The time is coming when such a laboratory will be as much a part of a good school equipment as blackboards, books, and charts are now." With such a prophecy ringing in our ears, we cannot simply fold our hands and wait. There is, indeed, all the more pressing need for small beginnings, for it is these that convince a

1 Charles W. Eliot. 
public. Once resolved to try, opportunity comes halfway to meet us. In fact, many an unexpected one stands knocking at our very doors. Even a tiny plot, hearth-rug size, can be made to do duty as a garden, inasmuch as in these days of intensive farming the size of a field is the very least of its assets. Says an expert farmer who heartily encourages the pocket-edition garden: "No man knows yet the capacity for plant growth of one square yard of earth." Large fields, then, may be dispensed with, but this cannot be said of large enthusiasms. Especially in the early steps of pioneering there is needed a discerning eye and an understanding heart.

A champion of children's gardens is found in Uncle John, 1 long the devoted garden correspondent of so many boys and girls the country over. His enthusiasm is such that all those about him catch fire. Just one little incident will show how far the sparks may fly. One spring morning he made with some friends a pilgrimage to old Boston. Rambling through the North End, they came upon the Old North Church, and, like all visitors, climbed a hundred or more steps to get a bird's-eye view of the famous landmarks. L'ncle John had scarcely reached the top when he burst out, "Look at all the little gardens!" True enough, viewed from this historic tower, the whole region, in spite of crowded tenements and crooked streets, might fitly have been named the garden quarter of the town. For as far as eye could reach, gay little gardens dotted the housetops and fire escapes. They were springing out of window boxes, old pans, cracked dishes, and what not. On every side the exquisite young green of garlic, lettuce, radishes, and onions was stretched up in response to the coaxing warmth of a ten o'clock sun, while nasturtiums and morning-glories were winding and twining around whatever their tendril fingers could clasp, here on a spout and there

${ }^{1}$ John W. Spencer, Ithaca, New York. 
on a clothes pole, their blossoms flashing here and there through the green.

The foot passenger hurrying along the thoroughfare, or threading his way through the dim alley, would never by the wildest chance guess what is going on up above the noisy world. And yet this striking picture, if only he could see it, would go far to convince him of two things: that nature, if she is coaxed ever so gently, will come more than halfway to meet a plant lover, and that hard-pressed human beings are eager to make sacrifices for the sake of some green things a-growing, and so turn the most impossible spots into gardens.

Of all the significant details before him not one escaped the swift eye of Uncle John, who interpreted them to his ready listeners. The actual result of the climb to the steeple's height turned out in the end to be not so much a tribute to the historic past as the awakening in these pilgrims of a desire to understand present issues and to speed the civilizing forces of the future.

The best possible outcome of such an expedition would take some practical form. It might be the prompt canvass of one's own neighborhood to learn what could be done to encourage school and home gardens. And then the question would arise as to available land and how to pick out the most suitable spots. In the ideal situation there is no doubt that one of the "must haves" is a flood of morning and midday sunshine. The afternoon sun does not count for so much; it is in fact a "may have." If the land can further oblige by sloping gently toward the south and east, it will be to its advantage. This slight incline, too, is a point in favor of good drainage, only it should not actually lie on a hillside, or the richness of the soil will be washed away.

Next, the chosen spot begs protection from north winds. Sufficient shelter is often afforded by a building, a high fence, 
or a clump of trees. And yet it should be kept in mind that the presence of trees within the garden itself or crowding about it means mischief. The reason is not merely because they shut out sun, but because their roots thread the ground to almost incredible distances. A network of roots running beneath the turf in every direction and striking deep tells its own story. It is that the roots are drinking up from the soil the food for which, if they are planted too near, your precious crops will be hungering. The elm tree, for instance, is said to be the worst enemy a garden can have. Its roots steal away hundreds of feet to get nourishment. When once the site has been favorably passed upon, the next move is to study its special peculiarities, taking into account all its strong points and making each score for all it is worth. Since every set of conditions differs, slightly at least, from every other, no 'garden is in danger of being a replica of another. And yet kindred difficulties will confront gardens great and small. Some of the most serious are a scanty measure of sun, poor soil, and exposure to the ravages of obstreperous animals. Lack of sun, as has already been said, is the worst fault a garden battles with, and yet, even when the only spot in the neighborhood for a school garden is too deeply shaded, the plucky gardener will not own himself beaten. To be sure, he cannot move buildings or cut down trees, but he can cherish every possible ray of sunshine, and he can make up his planting list from the various desirable plants that can brave shade. Madam Nature herself, as we know, succeeds in making many an unsunned wilderness burst into blossom.

In the case of schools which have a moderate-sized yard, the choice is often made between a garden and a playground. Opinion is divided. Some persons believe that the aims of the two are nearly identical, and that one supplies the place of the other, while others, on the contrary, fear lest the 
interests will seriously clash. As a matter of fact each is vitally important in its own way. The combination of playground and garden, if well managed, has really a good deal to recommend it. Well-defined boundaries, of course, there would have to be, and the garden would need some special means of protection. For instance, one large city playground, laid out a few years ago by a civic association, is bordered by a strip of garden land divided into beds two or three feet in width.

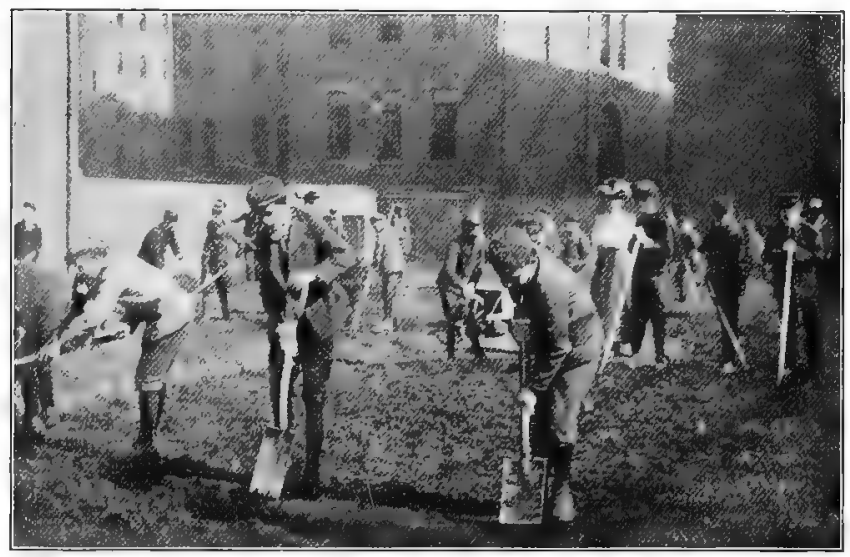

THE FIRST ATTACK

The suburban and country gardener often has good reason to grumble. But his grievances are a drop in the bucket compared with those of a city gardener, who is often at his wits' end to adapt a garden to his surroundings. Scant sunshine, shallow soil, or even a sun-baked pavement are likely to be his portion.

Whoever is bent on starting a school garden begins, of course, by inspecting the school yard. Nearly every school building has a yard, or an apology for one, which can somehow be turned to account. Even supposing it is bricked, 
permission can generally be obtained to take up the pavement. Bricks are not such sacred things, and they weigh as nothing in the balance with education. In case, howerer, any worthy city fathers are inclined to hesitate, it may be remembered that no voices in the community can be lifted in a more stirring appeal than the children's own, provided they have really set their hearts on having a garden.

It is not to be denied that the ebb tide of opportunity has positively been reached when gardeners are reduced to "farming it " on top of concrete. Thrifty little plots, it is true, have sometimes been so constructed, and a promoter of garden interests would not, of course, discourage even these. But with such handicaps the prospect from the agricultural standpoint is hardly good. Nevertheless it is claimed that the market gardeners in the environs of Paris, famous the world over for their skill, could successfully grow identical crops above an asphalt pavement. This is news to cheer any downcast heart.

As soon as a community has once been really converted to the idea of children's gardening, however, many an open lot can be found which the owners will gladly turn over, at least temporarily, to this public cause. Instances multiply to show how frequently in the outlying sections of cities and in the suburbs vacant land has been gratuitously offered for school-gardening purposes. The nearer such a lot lies to the school building, of course, the better. In a congested city district it is often the custom to get permission to use some tract of park land. The disadvantages of distance hare.been largely overcome by arranging that the school children shall go over to the park for their lessons, during the last half hour of a session, on two days in the week. In a park there is frequently some sort of shelter near at hand, where children can keep their tools. 
One garden director pictures thus the transfer of her classes from schoolroom to garden: "Twice a week during the planting, cultivating, and harvesting seasons, two processions, boys and girls, of fifty children each, can be seen marching, two by two, through the streets of the West End to their gardens. Over their shoulders, like a soldier's bayonet, are carried those worthier weapons - the tools by which human society has built its fabric - the hoe and the rake." 1

A somewhat striking example of what may be done with a ragged bit of city land is worth picturing in detail : This particular plot adjoined a school building situated in such a closely settled section that the only free space belonging to it was an irregular polygon squeezed into the space left by two brick buildings. Here the sunshine crept in during only a very few hours each day, so that everybody called it folly to undertake gardening against such heavy odds. Notwithstanding the heavy handicaps, however, a garden was finally laid out; and, curiously enough, as time went on this little plot became an inspiration to rumbers of young gardeners throughout the city. The ingenious planning, the good judgment in selecting the right plants, and the discrimination shown in massing against the fence a few tall and brilliant flowers made the place unique. One would hardly believe how many visitors from far and near were attracted by, this obscure little corner.

They were well repaid for their journey, too, they said, by a glimpse of the joyous children absorbed in work, and by the quite remarkable fruits of their industry. But by far the most gratifying result of this bit of garden was the love displayed for it throughout the whole neighborhood. What eager dark faces were always gazing over the fence! And what words of approval were murmured in Italian or in softly twisted English!

Report of Boston School Garden Committee. 
The question is often raised whether, in such a district as has just been described, only a few steps away from a crowded thoroughfare, where strangers are always streaming by, a garden can be kept safe from intruders. The answer is that, when properly organized, the young gardeners and their families are rightly considered a garden's stoutest defenders. The children's protective methods are sometimes very ingenious. In one instance at harvest time the garden was continually visited by loafers whom the gardeners were too young to get the best of, so they kept a camera in an adjoining house and photographed the trespassers.

It is well known that ownership in even a tiny garden arouses in the children of a community a true respect for property hitherto unawakened. Here, very likely for the first time in their lives, youngsters see things from the angle of the owner. In concrete terms, as soon as a child raises a melon and has that melon stolen, he recognizes the enormity of theft. This is not mere school-gardening sentiment; every grown person who has had experience in this matter says exactly the same thing. Yet granting that a change of heart may be accomplished through the influence of school gardening, only an old fogy will expect these conversions to be instantaneous. Few persons, moreover, except practical school gardeners, realize how many disasters can befall a garden, wholly apart from any deliberate mischief. A scrimmage for a stray ball is enough to spoil a whole spring planting; and as for the moral natures of cats and dogs, these still remain so unregenerate as not to hinder them from demolishing a thriving little farm in a brief quarter of an hour. One child voices his trials thus plaintively in his garden diary: "Every seed I have in the world is at the mercy of a dog." The subject of fencing is bound to perplex some gardeners. A fence or no fence is the question? This will depend largely 
upon local conditions. A fence often seems a needless expense, and in some neighborhoods it certainly is. Its being regarded as a necessity would, certainly under ordinary conditions, imply a lack of strong neighborly feeling. Still in some sections, where there is much idling on the part of strangers, or where animals run loose, or again where the garden adjoins a lively playground, it is clear that a fence may prove true economy.

On the other hand, one of the best examples of neighborly coöperation that has ever been observed by the writer was seen (of all places in the world!) in New York City. The garden was a vacant-lot experiment. ${ }^{1}$ Two young fellows in their teens took complete charge, and sold the fresh vegetables to neighbors who came to buy. Glancing at what was but an apology for a board fence, the visitor led up to the subject of trespassing, prepared for tales of woe. The dialogue went as follows :

"But are n't you bothered by meddlers, not to say thieves?"

"Oh, no."

"But this fence of yours can't do you much good."

"Well, you see, so many like to come in that I took it down in some places myself so that folks could get in easier." Is it any wonder that this garden was a success?

And yet if a fence is required for protection, then by all means put up one that will really protect. A fence five or even six feet tall, as for a tennis court, is not likely to be too high. In that case the wire netting should be strong, firm, and of fine mesh so that animals cannot sneak through. Of course it must not shut out sunshine or a view of all the interesting happenings within. Where no such fence is needed, the garden can be prettily inclosed by a flowering hedge or by a low wall covered with vines.

I Started by Bolton Hall. 
The garden having thus been properly inclosed, the next consideration will be that of soil. Just as no site is hopeless, so no soil is beyond reclaim. And yet one must not assume from this remark that good earth is not quite as necessary as a good location. The difference is that if the soil does not come up to the required standard, it can be made to order.

Portable soil is a term that explains itself. It appears that for some years the small gardeners near Paris have stipulated in their renting contracts that when they quit their tenancy they may carry away the soil down to a certain depth. A recognized expert says quite truly, "Instead of searching for soil, we are learning how to make it." In city gardens, indeed, the necessity of making the soil is virtually a foregone conclusion.

But whether the garden is in town or country, if it has any soil worth the name, the first step is to examine the earth carefully and then undertake to supply what it lacks. The way is to take up a handful here and there, in order that all parts of the land shall be fairly represented, then bring the samples indoors so as to examine them thoroughly and to determine whether the ingredients are chiefly sand, clay, or loam. That this is a practical method is indicated by one of the recent devices at the Iowa experiment station. It is what is known as a soil sampler, something on the plan of an apple corer, by means of which a solid core of soil, three inches in diameter and of any depth up to fifteen inches, can be taken out.

The school gardener will usually like to go on and make a few simple tests. ${ }^{1}$ Just an ordinary magnifying glass will reveal something of the character of these grains of earth. For one thing, it will show what a surprising amount of water is contained in one crumb of earth. Eren when soil looks

1 Public School Agriculture, Massachusetts Agricultural College. 
parched, the experienced gardener knows that it holds a quantity of what is called film water. On heating a little of the earth in a test tube, the glass becomes lined with tiny droplets that have been driven off from the apparently dry earth. To verify one's conclusions and to get further advice, a sample may be sent for analysis to the state experiment station. Owing to the small quantity under inspection, however, this method often fails to give satisfactory results.

Another matter for consideration is to what extent various soils retain the rain. For testing this some simple scheme can be devised to show at what rate water will percolate through the different materials. A good way is to set up several lamp chimneys, putting a sample of earth in each, noting how the different samples behave when watered. A sandy soil, it will be seen, allows the water to filter through in almost no time. A clay soil, on the contrary, drains very slowly, sometimes scarcely at all. Picture this on a grand scale and you have before you exactly what happens to the rainfall on a farm. In the first case the sandy earth would be left in a chronic state of drought, while in the second the water would settle in puddles. To take "any old soil" and mix into it the ingredients necessary to make it fit for all-round garden purposes requires good sense and no little skill. Of course, where there is really no true soil foundation, but only a waste of bricks and rubbish, the problem is even more difficult, since in that case a garden is not merely made but built. In the case, too, of hopelessly rough land the stumps and stones will first have to be removed, perhaps by blasting. Afterwards the humps and hollows can be leveled by spreading on a plentiful supply of loam, hauled by the cartload.

The item of loam in the expense book need not be so very great. Indeed, for school gardens enough loam of sufficient richness may usually be obtained free of charge from 
some out-of-the-way corner of the park. On the whole, it may be said that the more substantial the filling the better the crops, since some roots strike deep. The course that has just been suggested is the one most commonly followed in dealing with the "made land" in cities, where the ground consists mostly of gravel, ashes, and tin cans. A girl from the Winthrop School writes nairvely, "When we were digging we found many curious things. There were stones, worms, broken glass, and bricks."

The question of enrichment - what and how much - will nowadays accept nothing short of a scientific answer. A thorough knowledge of what substances to use, and how to use them, is to-day a necessary part of a farmer's equipment. He must at all costs keep up with the new methods that are being introduced every year. Sometimes our young gardeners will begin by verifying some of the commonly accepted rules about fertilizers ; then they will be enticed to work out experiments wholly their own. Practical knowledge is gained by watching the effects of different sorts of fertilizers on selected plants arranged in separate boxes. Among the commonest samples are to be found such stand-bys as nitrate of soda, acid phosphate, muriate of potash, and some forms of "complete fertilizer," as it is called, not omitting samples of barnyard manure. Other samples then can be tried whose effects are less familiar.

There are all sorts of clever ways of applying fertilizers. What gardeners call a " quick start," for instance, is secured by making a somewhat deeper furrow than usual, scattering in some fertilizer, then sprinkling on top a light layer of earth before sowing the seed. But it must be emphasized that by far the most effective, as well as the most commonly used allround fertilizer, is well-rotted barnyard manure. "Well-rotted" means that decomposition has been going on for at least a 
year. As to quantity, roughly speaking a cord of this manure will be required for a field seventy-five feet square. Liverystable manure is of much less value, owing to the fact that it contains a large proportion of straw. This very objection, however, works to the advantage of land wherever a too compact soil needs to be lightened. A clay soil, for example, calls for some sort of filling to make it porous. Wood ashes, for the sake of the potash it contains, is very valuable. Twenty cents is not an unusual price for a bushel, so that every handful should be saved. Coal ashes contains, of course, no plant food, but it is in some cases used to improve the texture of soil. Pigeon and hen guano make desirable fertilizers where a highly concentrated form is wanted. Some give these highest praise. Applying fertilizers should always be done cautiously. Of many a once-promising grassplot it can all too truly be said, "A burnt lawn dreads the fertilizer." This is especially true of prepared dressings, for they are highly concentrated. Therefore never allow a particle to touch any part of a seed or plant. Guano is said to be the one exception.

In cities, street sweepings play an important part in enriching land. They may nearly always be delivered by the street department for the asking. The farmer did not exaggerate when he said: "I saw a man dumping a load of street sweepings into a vacant lot. It would have been less wasteful to have dumped a bushel of potatoes into the hole."

Manure and artificial fertilizers are both expensive ways of restoring the food elements to the soil. This accounts for the starved condition of many a worn-out farm whose owner believed he was too poor to properly feed his land. But while he has seemingly been getting something for nothing, his farm has been steadily running down. This is called skimming the land. 
A recent writer gives such a person no quarter. He says : "The individual who deliberately fails to return to the soil its fair share of the product abuses nature, cheats and degrades himself, robs his children, defrauds the future, and is not an intelligent, patriotic citizen."

It is a blessing that new and more economical means of fertilizing have supplanted the old. The three most valuable chemical elements supplied by fertilizers are potash, phosphoric acid, and nitrogen. Nitrogen, the most important element in manure, happens to be the most costly of the three.

Until recently it was believed that green plants could under no circumstances feed on free nitrogen, but that they must use it in some one of its chemical combinations. This is doubtless true of most green plants. It has, however, been found that one class of plants is able to collect free nitrogen from the air mixed in with the soil, and stores this in its roots.

These legumes, or pod-bearing plants, including the clover, vetch, and pea, as well as alfalfa and soy bean, bear little nodules, like warts, upon their roots. The nodules are made up of a lot of microscopic plants, or bacteria, ten thousand or so to the square inch. The free nitrogen in the air supplies these bacteria with food. Besides using the free nitrogen as food, these bacteria store it, or "fix" it, as the term is, so that later the whole plant may get the benefit of it. Moreover, through the plowing under of nitrogen-fixing plants the earth becomes enriched by just so much new nitrogen. To-day these tiny organisms alone are saving farmers millions of dollars in fertilizers. In some cases, however, it happens that these leguminous plants do not develop nodules. But if nodules are lacking, they can be supplied, so scientists have learned, by inoculation. The formula for inoculation is simple, so that the process has frequently been carried on even by 
school children. Some boys ${ }^{1}$ gave an account of their interesting work in the following words :

We wanted to grow a patch of cowpeas. We sent to the laboratory and secured a small packet of sterilized cotton fiber upon which nitrogen bacteria were growing. We received, besides, two little packages of chemicals. We were told to dissolve one of these in a bucket of water and then drop in the cotton containing the organisms. The next morning we mixed in the second chemical. By simple division, the bacteria grew so numerous as to make the water milky. This preparation was then sprinkled on the seed just before planting. As the roots sprout, the bacteria find their way to them. They at once begin taking in and storing up the nitrogen in the atmosphere.

Many such experiments are recorded. ${ }^{2}$ A common but convincing test is to plant two strips with peas, treating one with fertilizer and the other without. To quote one out of many actual records, "The inoculated seed in the first row did as well without fertilizers of any kind as the uninoculated seed did in the second row, loaded as it was with fertilizers at the rate of 800 pounds of phosphate."

On the principle that a pound saved is a pound gained, no careful gardener will underestimate the value of his compost heap. A compost heap provides for the saving of every scrap of material which can by hook or by crook be turned into plant food. And so in the autumn all old stalks and withered leaves, in short everything that will in time make soil, should be raked into a pile and given a chance to decay. To hasten disintegration it is well to dampen it from time to time, covering it over with boards or with a barrel without a head, so that it will not look unsightly. In fact, screened with vines, this can even be made into an attractive corner. After the pile has been decomposing for several months, mix with

1 In Miss Mailman's class, Rice School.

${ }^{2}$ United States Department of Agriculture, Bulletin . Io. 214 . 
it some animal manure and spade it into the ground; this makes admirable fertilizer. Beware, however, of just one thing: do not spade in the seeds that remain hanging on old, dry weed stalks. This would bring a harvest of troubles indeed. Instead, kindle a bonfire of all such weeds and in good time stir in the ashes. Better still, make a large scrap. basket of

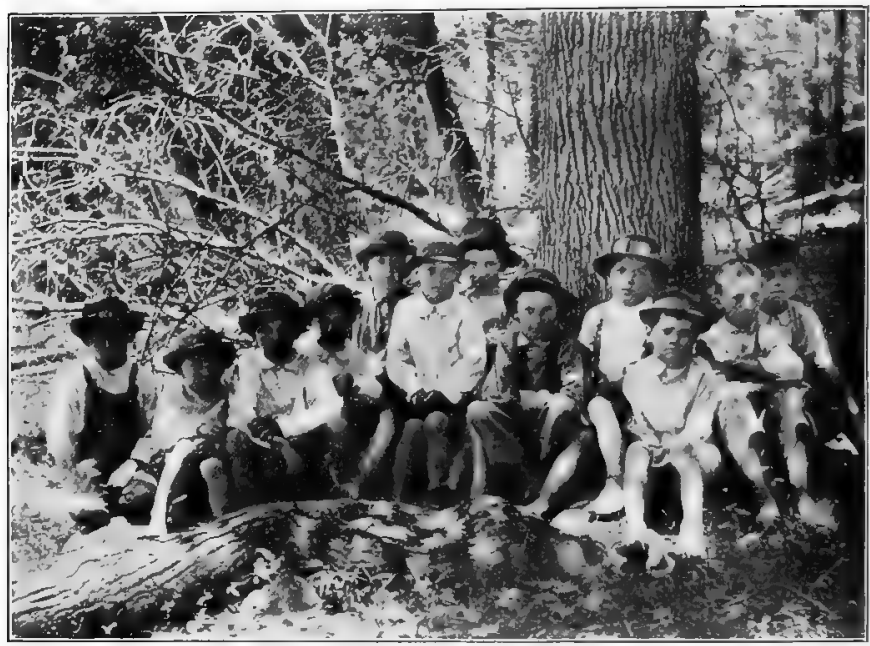

ALABAMA'S FUTURE FARMERS ${ }^{1}$

stout wire netting. Put it in an out-of-the-way place and, when full, set fire to it without removing the scraps.

Mr. Gladstone thoroughly understood garden economies. One day as he was strolling in his garden, so a visitor relates, there fluttered across the beds a scrap of paper. He caught it adroitly with the tip of his cane and, pressing it into the earth, scraped the soil well over it. Such a simple act illustrates the instinct of the true gardener.

1 These lads have made an expedition to the woods to get leaf mold for their garden. 


\section{CHAPTER IV}

\section{PLOTTING AND PLANNING}

Laying out grounds, as it is called, may be considered as a liberal art, in some sort like poetry and painting, and its object, like that of all the liberal arts, is or ought to be to move the affections under the control of good sense. If this be so when we are merely putting together words or colors, how much more ought the feeling to prevail when we are in the midst of the realities of things. - WORDSWORTH

What the main garden shall stand for and what space shall be devoted to side issues will be the all-absorbing question as soon as a site is chosen. Up to this time imagination will have set no limit to the dazzling possibilities conjured up by a brotherhood of young Aladdins. They will, however, be only too glad to exchange the lamp of their imaginings for some real proof of skill and strength. The first test given them (and one upon which more depends than they realize) consists in fixing the garden's boundaries according to precise and carefully considered measurements. In deciding what these lines shall inclose, it must not be forgotten that in these days of intensive gardening a trained agricultural conscience will not allow a scrap of the inclosure to go to waste. Far better, therefore, for the student of modern methods to begin by tilling too little land than too much. One needs only to read agricultural bulletins to be convinced that what really counts is the quality and the abundance of a yield in its relation to a specific area, large or small. An expert, for instance, scores not because he can harvest a certain amount of corn, but because he has discovered a way to make two ears of corn 
grow to-day on the spot where one grew yesterday. Feats like this (for feats they truly are) stand for something greater than mere individual triumphs. In so far as these discoveries benefit the world, they are justly valued as forms of high social service, and they win distinction accordingly.

All other schemes come to a standstill while the little farm is being correctly staked, the survey recorded, and a map drawn to scale, giving each detail, the points of the compass included. Now is the time when slow and steady wins the race, for not only must the measurements be taken deliberately, but they must be verified many times over, and from a number of different starting points. In the lexicon of the young surveyor there is no such word as haste. At this stage one careless slip has more than once been the undoing of a beautiful plan.

The task of surveying a home garden, even though it should be divided into plots, is of course comparatively slight; but when a whole class - including the quick and the slow, the lame and the lazy - undertakes to plot a school garden in concert, each doing his share, surveying becomes quite a different story. This is indeed exploration.

The children set out together like a band of pilgrims. Now any such company, starting on a quest, would surely expect, sometime in their course, to see rising up before them the hill Difficulty. Indeed, they would be honestly disappointed to find the experimental life on too "dead-easy" a level. But somehow they do not look for this hill at the very start-off. Nevertheless, - there is no disguising the fact, — it is looming up already in the path of our young friends in the shape of a problem in plotting. To-day, as of old, there is a choice of ways. One way curves conveniently around its base; this means that older persons may do all or most of the thinking. a responsibility which, out of a mistaken sense of kindness, 
they are often only too ready to assume. The other is the narrow way that leads over the crest; and this, if followed, means that the children gallantly do this work themselves. Well for them if they decide upon this latter path, for the exercise of clambering up such hills is in itself the best part of a liberal education. Moreover, the ravines and precipices which look so formidable to one lonely wayfarer can be conquered right merrily if the pilgrims are companioned by a common cause which they have entered into with all their hearts. For in the plotting of a garden all the qualities which the youngsters possess in common, such as mathematical accuracy, initiative, patience, and good humor, are called out by the occasion and shared by all. Lucky children are they who, before their fingers grow clumsy, have a chance to acquire manual skill, and who, before their dispositions get cranky, can practice social combinations.

If at this crisis mathematics makes for good gardening, it is just as sure that gardening makes for good mathematics. For it has been found that by the time the area, with all its jogs and irregularities, has been worked out, first on the land itself and then on paper, the width of the paths settled, and the beds outlined, not to enumerate all the details of secondary importance, the "art of computation" and the "science of numbers" - in the language of the ancient textbooks will have lost all resemblance to a certain unpleasant specter of old, and will appear in friendliest guise as a flesh-and-blood reality. Experience, moreover, shows that no stimulus, however artfully contrived, will whip a lagging scholar at so smart a gait along the road to quick and accurate figuring as a genuine obligation to his self-elected work and to his fellows.

The load of measuring may be lightened according to the means employed. To begin with, gardeners are advised to invest in a surveyor's tape. A garden line will be required 
besides; in other words, a stout cord that will not stretch. If possible, get one long enough to extend the entire side of the lot, then fasten an iron hammock ring at each end to prevent the line from slipping or by chance from being twitched out of one's grasp, - for these provoking little incidents sometimes

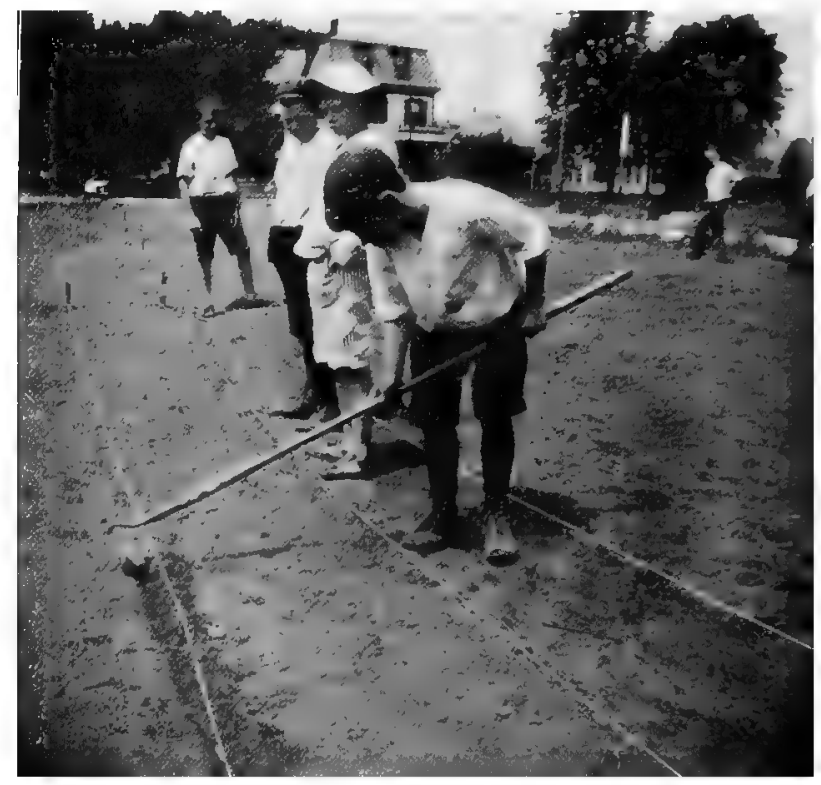

LINES THAT DO NOT SLIP

do happen. The rings will readily slip over two corner stakes and hold the line steady while intermediate measurements are being taken. They can also be used to hang up the line by, when these measuring days are happily over. It is a good plan to knot or otherwise mark on the cord certain definite distances, such as the width of paths and beds, so that these may be located with the least possible trouble. 
Time- and trouble-saving devices innumerable will be suggested by inventive boys and girls, who will now have their special innings. Some of these devices, to be sure, seem rather trivial, especially before they have been tested ; but all may well be given a trial. One would hardly realize, for instance, how cleverly a little clothespin will lend its aid ; as an article for holding strings in place it certainly takes the lead, pushing as it does so firmly and neatly into the earth.

When the garden plan is finished, there will doubtless be several copies of it made. One will be kept "for best" and will be posted on some convenient wall for reference. 'Lettered plainly, it will reveal at a glance many interesting things; it will tell what proportion of the land is to be given over to general kitchen-garden purposes, what to the experimental beds, what to a little nursery, to small fruits, to ornamental shrubbery, flower plots, and borders. In the case of a small inclosure that is expected to produce a variety of vegetables and flowers, some of which can get along with less sun than others, one is recommended to mark out quite definitely the areas of sun and shade that can be counted upon. These, of course, will change to correspond with the sun's path as the weeks go by.

The place of honor, however, in any well-regulated garden will be reserved for the cold frame, since within it there will be reared hundreds of little plantlings with which to stock all the rest of the garden. Spare no pains, therefore, in choosing for it a spot that combines the most complete shelter with the most splendid sun exposure. For nowadays, even in very modest home and school gardens, the cold frame is very properly playing a leading part, and every day its value is being more and more appreciated.

Desirable in every way as it would appear to work out the whole plan (this being in accordance with the advice offered 
by the best gardeners), too long a look ahead must not be expected of children, for experience has not yet taught them foresight. As a rule they are only interested in the details of the' near future. And yet just such work as this should help them to become excellent planners. On every occasion they should be encouraged to view their grounds in imagination from this angle or from that, from a window or a flight of steps. Experienced gardeners, when arranging flower beds, picture them as vividly as possible during the procession of months, painting them in their true colors and foreseeing just where gaps are likely to be left when certain plants stop blooming. The best places for the permanent shrubs and vines, whose beauty will often consist of berries and fruit as well as blossoms, like the bittersweet and the barberry, will, as far as possible, be decided now, though it is not probable that all will be set out the first year, nor is this desirable.

According to one of his friends, Saint-Gaudens had a delightfully simple method for the effective laying out of flower beds. He would lay down laths to indicate where the paths should be, then move them nearer together or farther apart to widen or narrow the paths until the beds "looked right." Carrying this practical method a bit farther, some stick up bits of brush where shrubs are to be. This is, as it were, "trying on the garden's dress." I It certainly helps wonderfully in training the garden imagination.

While children show a good deal of independence in their choice of plants, they constantly ask the opinion of grown people, particularly in regard to flower beds; and their eager questions open ways truly to befriend them by a few wise hints, for there are some underlying principles in landscape gardening which everybody should know, and which may well be learned early. Some of them are embodied in the following

\footnotetext{
1 Miss Frances Duncan.
} 
simple rules: When in doubt, follow nature. Avoid, as a rule, planting flowers in stiff rows, unless, of course, some special occasion may require it. Avoid indulging in fanciful effects and geometrical or picture-puzzle shapes; lend a willing ear to Sir Francis Bacon, whose advice is as timely to-day as it was three hundred years or more ago, when first it was written.

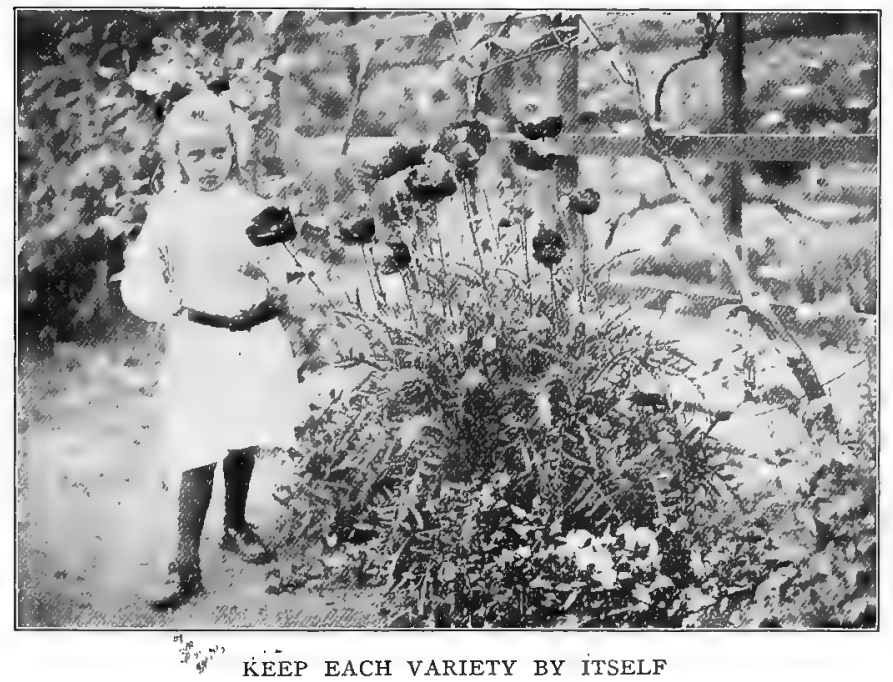

"As for the making of knots or figures," quoth he, "you may see as good sights many times in tarts."

To venture upon one or two more hints: Every path should lead somewhere; it should not wind without good cause. Tall plants will be most effective if placed behind low ones, not mingled with them. Keep each variety by itself; mass, do not mix. Blue and yellow flowers are cheerful and sunshiny. Use many white flowers near the gay-colored ones; this brings out the beauty of both. Avoid monotony by having plenty of green; therefore protect the foliage of plants from insects as 
carefully as you do the flowers. Plan, as has already been said, for a succession of bloom extending from May to late October. Any one who will sclect his plants with this in mind can have a garden gay with blossoms the whole season long. Above all, remember that a fussy garden can never be beautiful.

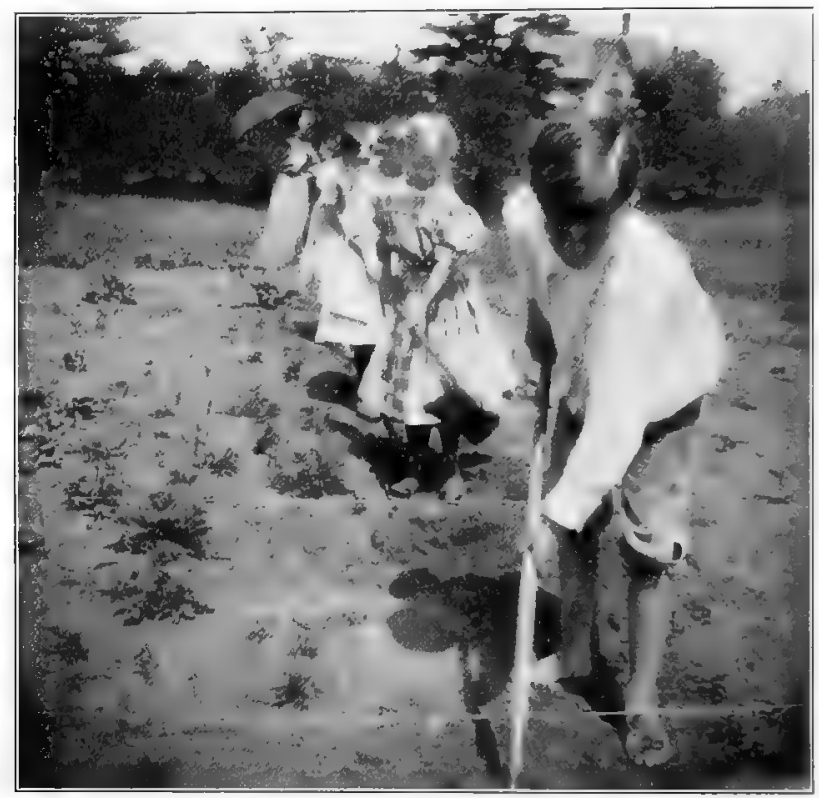

STRAIGHT IS THE LINE OF BEAUTY

The charm of a flower bed, as we probably agree, depends a great deal upon its harmonious arrangement. The vegetable garden, on the contrary, does not indulge in any picturesque effects. Its beauty lies in severe simplicity and scrupulous care. In spite of copy-book precepts - in this case at least straight is the line of beauty. This will never be better demonstrated than by a visit to some flourishing market garden. 
Nothing is more exhilarating on a bright day than the sight of a superb market garden in full swing. The smell of the rich earth, the orderly furrows sketched in living green upon the black soil, seeking with one accord a vanishing point in the far horizon, and the unhurried industry of this complete little world where each man is bound up in his special work, - all these captivate the imagination. To crown all comes the economic test. A noble harvest of foodstuffs is waiting in bountiful heaps, to be delicately packed for shipping and for the city market. Inquiry proves beyond question that the financial status of such an industry is solid. The business is organized to earn every possible penny.

It is remarkable how quickly youngsters catch the rhythm of a place like this. Many a one who has started out of a morning in the spirit of frolic will come back from his visit quite sobered. Whatever else may have been accomplished, the trip will not be likely to fail in giving exactly what was expected of it - a capital idea of a true market garden. Nevertheless, to hold this up as the one and only standard of excellence for a school garden would of course be a mistake.

It is plain enough that if this point were overemphasized, the miniature-farm idea might lead to mere superficial imitation. This would ruin, educationally, the promise of a garden's best work, where a small space is to be worked, not by one dominant mind - of an Olympian, shall we say? — but by many minds as well as many hands. A method in which there are few, if any, difficulties is one which has sometimes been adopted in a coöperative garden to secure a farmlike basis for vegetable growing without at all cramping the ambitions of the individual planters. First divide the entire space into long strips four or five feet wide, with paths of not less than three feet between. These strips, by the by, should preferably run north and south, so that the sun will fall impartially 
on both sides of a plant, which will thus attain a symmetrical leafage. This bit of real estate can then be subdivided into "lots to suit," with no restrictions, as the advertisements read, so long as it is controlled by the workers themselves, divided amicably according to the schemes they have in mind. Then by reducing, as far as possible, the number of cross paths, we can economize space, and the artificial, checkerboard effect of many school gardens, which is quite unnecessary, can be avoided. Some do not object to this patchy and wholly individualistic method of division; other persons do object, chiefly because it neither expresses nor encourages any coöperative association on the part of the workers. Indeed, it gives quite the opposite impression, for it copies rather the rows of isolated desks in a classroom, so suggestive of mental and spiritual quarantine.

It is not to be understood, however, that further division of the land for some real purpose is in any way objectionable. The point is always to have the entire planting done not at the bidding of some grown-up autocrat, kindly and wise though he may be, but by the mutual agreement of the workers. This once accomplished, appearances can safely take care of themselves.

Suppose the strips to be subdivided into various sections; then each individual or each coöperating group of children can cultivate one or more of these sections according to any basis that all consider fair. Some schemes in their very nature will need more space than others, some less. One group of workers will specialize in variations of the cabbage tribe, collards, kohl-rabi, cauliflower, etc. Another group will watch the effects of the different fertilizers. Still another will perhaps engage in the business of flower culture. Whatever specialty happens to be seriously chosen, it will bring in its train plenty of wholesome education. Who shall say of these electives 
that one, even if suggested by a graybeard, is intrinsically better than another? although better it certainly proves for the education of the young person whose heart is in it.

In the course of all this plan making and unmaking, it is inevitable that some false gods be shattered. City children, for example, accustomed all their lives to banked-up flower beds in public parks and gardens, seem possessed to perpetuate these in their own gardening. They are not even content with following their model with reasonable zeal, but in the process of path making they will be seen carefully scooping the earth out deeper and deeper, enhancing, as they firmly believe, this beautiful effect, which finally becomes grotesque, if not actually gruesome in character. In a park, of course, this special treatment of banking the earth is often given to bulbs and to plants that have been nursed in hothouses and then transplanted on the eve of blossoming for a few weeks' display. But in genuine, everyday gardening there is nothing to be said in favor of such mounds. Pause a moment and you will see that in such cases the water is drained off to a lower level so quickly that the roots are sure to starve.

So far we have been discussing the matters of general concern; the time has now come to talk over the various specialties. These, too, concern everybody, but not all to the same degree. The wide difference in children's personality is now brought into high relief. Students of a certain type, for instance, are so constituted that they will quite contentedly carry on a garden plot which is the exact counterpart of their neighbor's. Perhaps they may as well be allowed to form this habit. By some teachers no special obligation to such natures is recognized, beyond letting them jog comfortably along the great highways that others have trodden smooth, keeping constantly at their heels, however, to see to it that no actually assigned task is neglected. It seems often to be taken for 
granted that a large proportion of pupils are predestined, into whatever calling they go, for the mediocre, not to say under-dog, positions in life, - the very positions, of course, for which throngs of applicants are always pushing. In the old world of class distinctions this question would probably

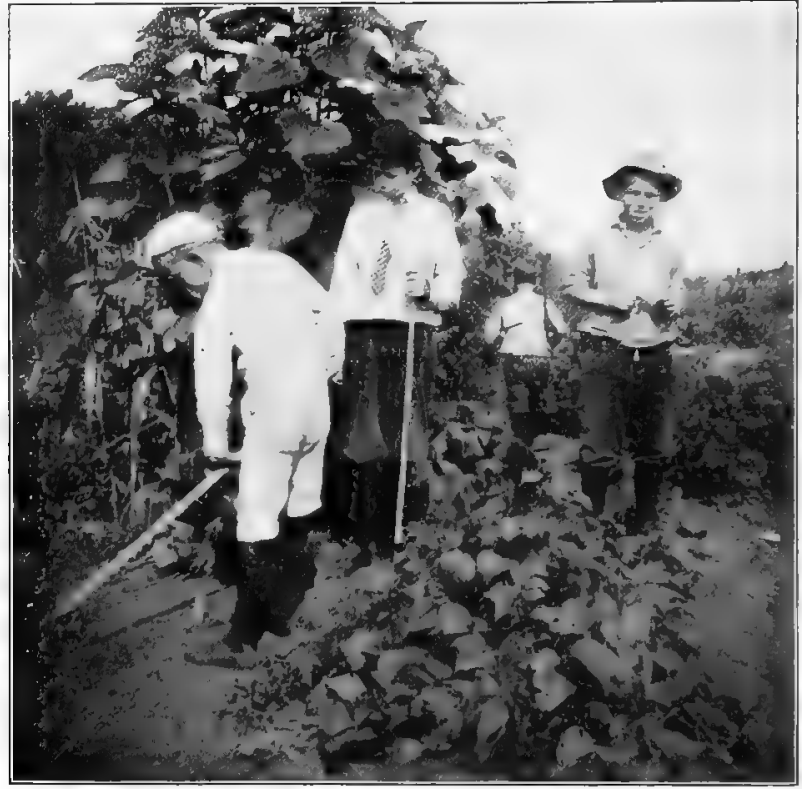

THEIR EXPERIMENT PLOT

be quickly disposed of. In the new world, and especially in the new education, the questioner will not be silenced. It is, in truth, constantly being asked whether every little spark of initiative is not capable of starting a very good bonfire, if not a big conflagration, and whether a puff or two, well timed, might not set it ablaze. Our attitude all depends upon whether we intend to train young people out of mediocrity or into it. 
On the other hand, there are students of another type, in whose veins the spirit of adventure runs high. The chance to carry on an experiment plot of their own instantly appeals to them. These plots, since they are to be of so miscellaneous a character, may for convenience be placed a little apart from the main farm. In such an experimental plot some pet theory will be tested, or some phenomenon that has excited curiosity will be hunted down. This is the kind of work that calls out the power of leadership, and of all others this is the place to encourage those who have the smallest germ of scientific interest.

Some unimaginative person may, half in earnest, call these plots space set apart for whims. That we may not inadvertently fall into this error ourselves, it is well to remember that the scientific discoveries which constitute the vertebræ of civilized life to-day once originated in what appeared to be the fruitless chase of a foolish notion. Certain it is that excellent people grasp this truth perfectly in theory, only to find that in practice it slips like sand through their fingers. This is more than likely to happen when they are watching, a little impatiently, some of the crude but sincere attempts of children, and want to hurry them. There are plenty of teachers who will testify that some of the experiments which at first struck them as most fantastic are the very ones from which a class in the end derived the most solid benefit. The following extract from a boy's exercise book will give a slight notion of the attitude of some seventhgrade boys toward their garden experiments :

\section{MY PLAN TO RAISE RICE}

The way to raise rice is to have a swampy place and a warm place. In our school garden we had no swampy place, so we had to draw plans of how to keep the ground swampy. My plan was to dig down two feet, 
put boards on both sides and bottom, put clay in the cracks, and fill it with dirt three quarters full and soak it with water; then plant the seeds and water it twice a day.

The way it was carried out in the garden, we dug down two feet and then we made a wall of stones and sidewalk bricks. We then filled the cracks with clay. We mixed some clay with dirt and put it on the bottom. We put some soil on top and then planted some seeds, etc.

And so for weeks, in perfect seriousness, the record of this experiment continues. Of course no crops of rice were ever harvested. Silly, then, to try. Perhaps ; but more foolish it would have been to discourage the growth of sturdy perennials like initiative and concentration, particularly when these spring up so spontaneously and are content to flourish in a mudhole.

The plotting of our garden may now be considered finished; and the planning, in the rough, is finished, too. Yet, in a sense, planning has only just begun. It is, in truth, never done. The fact is, the best kind of garden at home or school grows somewhat after the fashion of a living organism. Fed constantly by fresh ideas, it keeps building new tissue, as it were, and adapting itself to new needs and conditions. It must, for it is in the hands of young human creatures who are growing fast themselves.

Most upsetting, of course, such changes must be to the, mature mind, which demands not dissolving views, each more entrancing than the last, but a finished picture in March of what is to be realized in June. If exacted by some person in authority, such perfection, however, can easily be reached. It is only necessary to take the appropriate course. This consists in proceeding very much as a real-estate owner would proceed in building a block of houses. In such a case it is expected that the plans, together with the specifications, will simply be passed over to the contractor. 
And yet, much as we may scorn, on the one hand, the tourist who cannot deviate a hair from his scheduled trip, on the other we deplore the habit of aimless wandering. In gardening, what a grown person is for is not to personally conduct the trip, but, as an expert, to help test the texture of children's plans, and to find out whether the stuff these are made of will stand the strain, or whether it will fray and pull.

At last, when all the mistakes and all the imperfections have been bravely faced, with high hope everybody looks forward to "next year." And sure enough, another season comes round, opening a beautiful new page on which little men and women may write. 


\section{CHAPTER V}

\section{A WORD FOR GOOD TOOLS}

Through cunning, with dibble, rake, mattock, and spade, By line and by level trim garden is made. - Tusse $R$

When the children's school farm in New York City was started, the children were equipped with just one tool - a clamshell. With this insignificant weapon, as the whole schoolgardening world knows, they made a splendid attack. But even a ten-year-old child, as he goes on improving, wants the right tools. He wants them so much that he will do a good deal on his own initiative toward getting them. So in the spring, when youngsters begin to discuss tools with the same eagerness as they do bats and marbles and are found poring over catalogues away past bedtime, it is the moment for a grown-up to step in and offer his experiences, and show them how to make their pennies go farthest.

When enthusiasm is at the full, one teacher makes a practice of inviting his class to visit with him one of the great agricultural supply houses. Here are stacked a truly bewildering assortment of implements and machines. Young people enter a new world; they cannot help being fascinated by these complicated and ingenious inventions. Of course they must examine all the articles in detail, and handle everything, lingering always longest, to the concern of the teacher, over tools which have fine-cutting edges. The obliging dealer will be peppered with questions. All at once the children begin to grasp what this tremendous industry stands for. They learn, besides, that agricultural machinery constitutes 76 
one of the chief exports from our country, and that American implements are in demand the world over. One of the most interesting exhibits at Paris, in 1900, was a collection of agricultural tools, - stepping stones of progress on parade they might be called, - arranged in chronological order. The curiously archaic forms of the primitive tools led off, then appeared the gradual improvements made at different epochs,

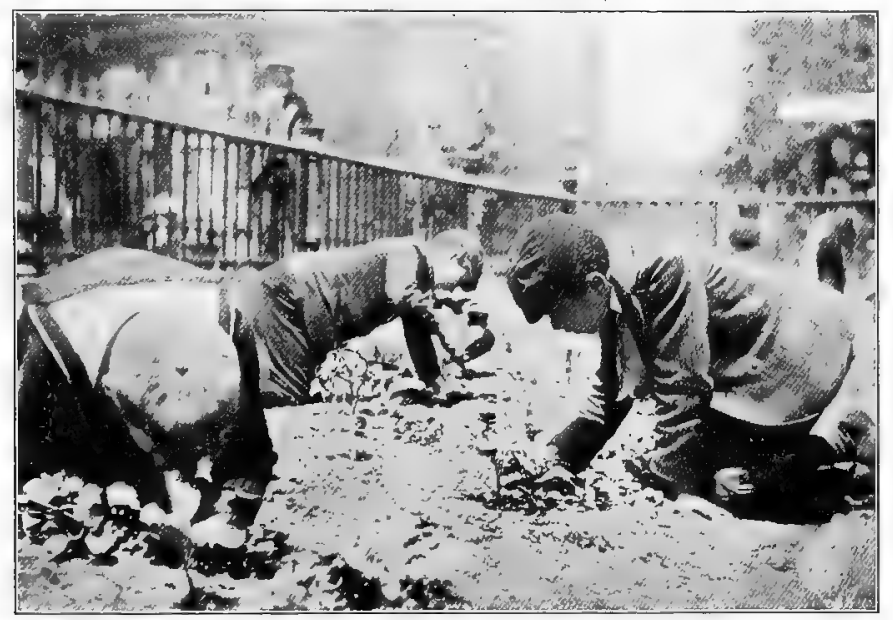

HANDS MAKE THE BEST ALL-ROUND TOOLS

until, bringing up the rear, were displayed all the most intricate modern machines. A rapid glance revealed the complete history of agriculture and explained its enormous leap ahead, at the present day, by the help of machinery.

Most of the new and clever devices for economizing labor are to be seen in actual service at any flourishing market garden. It is a part of the business of the school gardener to understand agriculture in all its giant proportions, and to appreciate appliances and what they stand for. It is also 
necessary for him to perform skillfully the work of his own small domain without too much expense, and to realize that hands are, after all, about the best all-round tools.

This brings us face to face with the all-important question as to what tools are positively needed in a school garden, and what they will cost. Some of the articles recommended are so simple that they can hardly be called tools except by courtesy; and yet the list has been found to meet amply all demands of everyday planting. According to the use to which they are put, there may be said to be three generic tools. These are the plow, the harrow, and the cultivator. On small grounds the spading fork answers for the plow, the rake for the harrow, and the hoe for the cultivator; in fact, eight simple tools are quite enough to make a fairly good outfit. The large tools selected will be the spade, spading fork, hoe, and rake; the small tools will be the trowel, excelsior weeder, a heavy iron spoon with an iron handle, skewers, and wooden labels. The labels and skewers can be whittled out by beginners in woodworking. Children so occupied will be doing real things and will thoroughly enjoy doing them.

For general use in the garden the list should be increased by a garden hose, a few watering pots, garden lines, and a wheelbarrow. The large tools are confined almost entirely to the work of preparation; consequently it is not necessary to have one tool for each pupil. To have a scant supply of small tools, on the other hand, so that the children would have to await their turn, would be false economy. In a garden class nobody should be idle for a single moment; this might well be called the First Law of the Garden. As an estimate of what tools, if properly managed, will fully answer the needs of a class of thirty, the following list is proposed: six spades, twelve trowels, six watering pots, six spading forks, one dozen 
hoes, one dozen rakes, and for each pupil a weeder, a spoon, and a skewer. The small kit consisting of these last three articles should always be at hand, because there is no time during the entire season when these tools will not be needed for keeping the land cultivated and for stirring the soil around the plants. The skewer does the work of a dibble; the trowel is wanted when a generous supply of earth is to be kept around the roots, and can be deftly applied to the ground near the stalk of the plant without disturbing it too much. Of course other tools could be added, like the spray pump, which would be very desirable. The entire cost of this outfit will come well within thirty dollars.

On the same basis that textbooks and stationery are supplied to schools for indoor studies, this modest equipment should be furnished for the outdoor laboratory. In neighborhoods where a number of home gardens are carried on, some of the more expensive tools can be owned in partnership. It will be found that coöperation for the purchase of tools and seeds, as well as for the disposal of produce, is for the advantage of everybody.

Beware of yielding to the temptation of investing in cheap or toy tools. They are very attractive, but they break easily, and such an outlay of money is simply thrown away; therefore go in for a better grade. Strong, honestly made tools, if well cared for, will last for several seasons. Proper care of them means that they must be thoroughly wiped when put away, to prevent rust. Every now and then they should be rubbed up with a cloth dipped in kerosene. A gardener is known by the tools he keeps; indeed, any true gardener hates badly kept tools. He will take pride, too, in the appearance of his tool room; to preserve good order, therefore, shelves may be put up for holding the smaller articles, while the large ones hang from pegs on the wall. Some schools recommend 
cutting a number in the handle of each tool, so that it may easily be kept in place.

Devices of all sorts for keeping the tools in order and in good shape will be suggested by the pupils themselves. This is one way of developing responsibility. At any rate, they should make their own rules and suggest their own penalties. Children may be chosen by vote to regularly inspect the tool room. How the tools were cared for in his class is told by a boy of thirteen in an exercise in written English :

\section{OUR GARDEN TOOL HOUSE}

The tools of the young boy gardeners of the Rice School are kept by a committee of boys called The Tool Committee. Their duty is to keep the house where the tools are kept in perfect condition and to provide the boys with tools. If a tool breaks or comes apart, there is a boy who volunteers to repair it.,

When the boys come to work in the garden, they form a line near the tool house and ask one of the committee to give him a certain tool which he needs for his kind of work in the garden. When a boy asks for a spade, he must need it for digging up the soil, or if he asks for a hoe, he must need it for gathering up the rubbish, and when he asks for a rake, he probably needs it to take the rocks out of his garden. Then there is a scratcher to pulverize the soil or to dig around some roots, and then there is a trowel to make holes in the ground and a water can to water the gardens. We try to have the tool house as clean as possible and see that everything is in its right place.

One season's experience will prove how great an advantage it is to associate with the gardening some instruction in woodwork. Not a day will pass without a frantic call for the carpenter. A few labels are unexpectedly needed; the handle of a shattered spade is to be cleverly sharpened into a useful dibble; a support must be devised for the hop vines before nightfall. Plenty of stakes and raffia should be always on hand for tying up vines and high-headed plants. Raffia 
is a tough, flat grass sold for just this purpose at all seed stores. It is the very best material, by the by, for tying cut flowers.

The far-sighted policy of the Children's Farm in New York is shown by the opportunity given the children to carry on the several kinds of handicraft which naturally accompany the cultivation of the soil. A course in woodwork connected with the gardening class will be found of the greatest advantage, if not positively indispensable. Indeed, a bench and a few carpenter's tools might well be included as part of the gardening outfit.

Garden occupations may be made more enjoyable for children and a great deal more popular with mothers if some attention is paid to appropriate dress. It is truly pathetic to watch a child, doubled over in absorbed interest, try to divide his attention between the gyrations of an earthworm and solicitude for a pair of light stockings or a freshly starched blouse. An apron or overalls, such as is neat and workmanlike for carpentry or for cooking, adds immensely to the carefree spirit of gardening. Made of denim or linen, it may be a pretty and becoming costume. Might it not work well for the members of the carpentry class and the sewing class to exchange courtesies? 


\section{CHAPTER VI}

\section{PLANTING}

It was one of the most bewitching sights in the world to observe a hill of beans thrusting aside the soil. - IIAWTHORNE

Of all the wonderful things in the wonderful universe of God, nothing seems to me more surprising than the planting of a seed in the black earth and the result thereof. - CELIA THAXTER

In planting, the main thought of the gardener is how he may manage to keep the whole of his garden busy all the time. His object is twofold. He aims to get as large a supply of vegetables as possible, but at the same time he is looking out for the welfare of the land. Leaving the sail idle for one short week means, of course, that the succeeding crop is retarded. More than that, it means that the effect of tillage is being wasted, and that a horde of weeds, not yet in sight, it is true, but surely advancing, has begun to claim the land for its own. The insidious drain made by weeds upon the moisture and fertility of fields is strangely enough not half realized.

In the old days the season for outdoor planting in northern latitudes used to be considered as extending from March to August, hardly longer. But tactics have changed, and now the season may be said to last all the year round. Grass seed, for instance, is sown while the snow still lingers in drifts. Winter wheat started in September will have shoots all ready to send up as early in the spring as any spots become bare.

Taking into account all these new possibilities does not, however, prevent the advisability of roughly mapping out a 
half-year of gardening into three planting periods : early, midsummer, and late. The early spring planting would include lettuce, carrots, radishes, onions, and early peas, to be followed by beans and corn; the midsummer planting calls for cabbage, tomato plants, and beets, and also for carrots again; the autumn planting includes such vegetables as celery, cabbage, and cauliflower, all of which will be set out as small plants, with the addition of such seeds as can withstand the hardships of winter. As a rule, do not replace a plant by one which takes out of the soil its food materials in about the same proportion; plan rather to replace it by a plant which will use elements that have not yet been largely drawn upon. The food in the soil can thus be made to go a great deal farther. A few general rules will save many a mistake. To begin with, it should be remembered that, classed according to diet, such vine plants as the cucumber and squash belong in one group; that the root crops, together with potatoes and onions (neither of which, of course, is a true root), belong in another; while the seed crops, beans and peas, together with the cabbage tribe and tomatoes, make a third. All those that belong in one of these groups have been found to use up the essential food elements in about the same proportions. This gives a simple basis for the rules of crop rotation. Cabbage consumes a great amount of nitrogen; so does corn. Corn and potatoes, on the other hand, draw heavily upon the supply of potash. Beans and peas, however, actually enrich the soil with proteids, which, as we know, are so valuable for the nitrogen they contain.

The subject of crop rotation is one that requires serious consideration. This deals with the system by which a carefully arranged sequence of different crops is grown advantageously upon the same piece of land. Such a scheme is directly opposed to the old-fashioned one-crop system, by which 
land, after a few years, got "all wore out." The plan of regularly changing crops is in a sense new, and yet on the best farms rotation has long been in vogue even when the scientific reasons underlying the practice have not been fully understood.

The method, after all, is nature's own. Whatever may be the explanation, nobody can have failed to observe how universally a natural rotation takes place in the yield of wild land. Let an oak grove be doomed to the ax, and lo! up springs a pine thicket. Cutting off the pines in their turn gives a signal for young birches to step quietly in. As for maple and ash clearings, the owner can scarcely turn around before the tangles of low-bush blueberry are up knee-high.

Not only is the amount of nutriment in land a matter which a farmer must understand, but it is necessary for him to know how deep the roots of a plant will strike to get its food. In this respect plants vary surprisingly. Clover and alfalfa roots are able to penetrate several feet; sugar beets and parsnips will not push down so far, but they will always root deeper than table beets and onions. Therefore in order to extract the food materials economically, — and this means more or less evenly, - it will be advisable in rotating to choose plants that feed at different depths. It is not uncommon for a farmerto use certain deep-rooting plants, like the turnips, to bring to the surface of the land food materials that lie out of the reach of his ordinary crop.

There is another reason for moving a given crop from place to place. Every crop brings, in its wake peculiar troubles of its own. One set of grievances to the farmer and his crops arises from fungous diseases; another comes from insect pests. The spores, or seedlike bodies, of each fungus thrive upon a particular plant and almost exclusively upon that one plant. Take the spore of the potato scab, for instance; this will grow on potatoes, but, as a rule, on no other vegetable. If 
potatoes were planted year after year in the same corner of a garden, the land would very likely become infected, and in time scarcely any potatoes in a whole harvest would be free from disease. If, on the other hand, when the first trace of scab appears, the potato patch is transferred to another spot, the fungus, faithful to its choice, is starved out.

Insects, to be sure, allow themselves a larger range of food supply than fungi do, not remaining constant to one plant. But still the plan of shifting a group of plants from one part of a garden to another is, for the reasons already given, strongly advised. The hard-pushed gardener grimly enjoys giving young insects whose birthplace has been nicely selected by the mother the surprise of a lifetime in a total change of crop.

Anybody who lives near a truck farm hears technical expressions with which he becomes familiar. Gardeners talk, for example, about catch crops; cover crops, and green manure. By catch crop they mean a crop that is planted between two money-making crops. A cover crop means some crop planted late in the season, chiefly for the purpose of holding the soluble food which would otherwise drain away. Clover is perhaps the best, but winter wheat and rye and turnips also make good cover crops. These are usually plowed under in the spring; they act in this way as a form of green manure. Green manuring means the planting of certain herbaceous plants for the sole purpose of enriching the soil. Some plant organisms are constituted so that they can successfully play this rôle of benefactor to the land. Those that stand preeminent as great soil renovators are the leguminous plants. It is a fact that three representatives of this family, the clover in the north, and the cowpea and the alfalfa in the south, have rejuvenated miles of worn-out farm land.

These few hints will at least serve to show how certain definite changes in crops are planned by the farmer according 
to accepted laws, and to explain why only a poor sort of manager could make so absurd a mistake as to keep planting cauliflower after cabbage, or cabbage after lettuce; for any thinking person can see at half a glance that rotation is not only the best policy, but the only policy.

Still another advantage of living near a truck farm is that one can watch the working out of clever devices in planting,

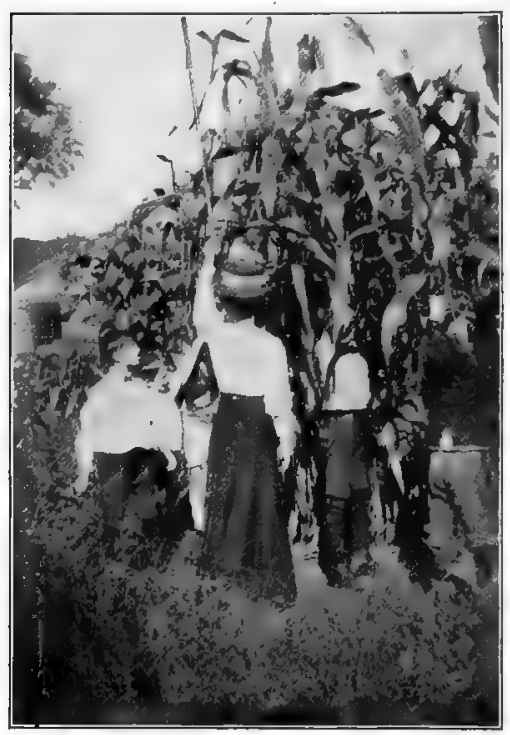

ROTATION PAYS by no means all of which are described in books. A neat scheme, for example, is to put into one furrow at the same sowing two kinds of seeds, one quick and the other slow growing. Radishes and parsnips, or radishes and carrots, according to this plan, start life as boon companions. While the parsnips are slowly creeping up, the three-weeksold radishes are ready to eat. Again, between rows of onion seeds one may put early relishes, like lettuce, radishes, and spinach, all of which will have appeared at dinner before the onions need space. After the onions are well along, turnips can be sown midway between the rows. Such a combination is spoken of as double or companion cropping.

Certain seeds are planted for the express purpose of helping others along. If, for instance, the two are sown together, the radish will hurry forward the carrot seeds. This is because 
the fast-growing radishes skirmish ahead and break the way for the more delicate, deliberate carrot seeds. Having served their altruistic purpose, the radish seedlings are weeded out.

Spare no pains to secure first-rate seeds. The wise farmer puts his trust in the best houses and does not get disappointed. He is not to be caught taking chances at the grocery store. Seeds bought at such places are often old and poor,

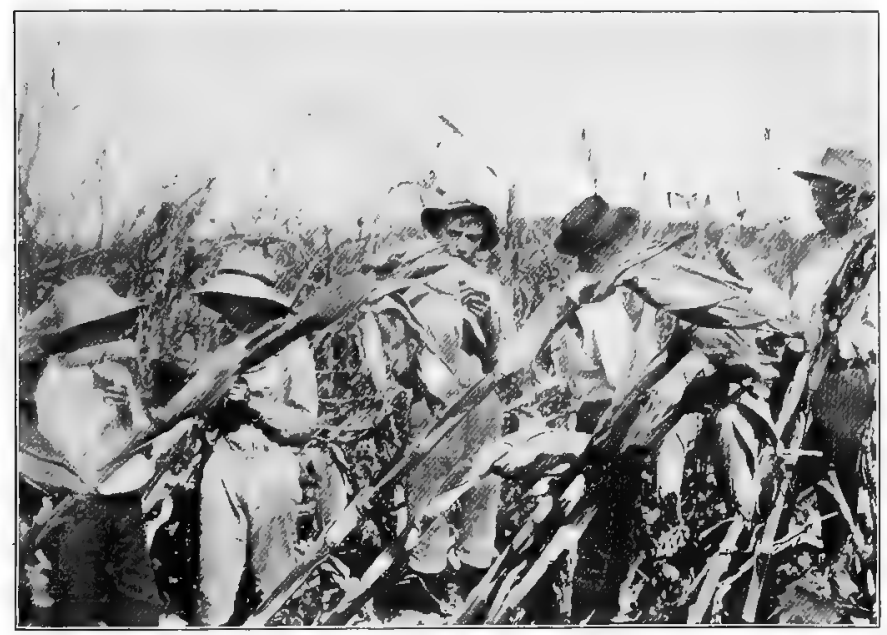

SOUTH CAROLINA BOYS MAKING SEED SELECTIONS

and the proportion of seeds that germinate has been known to fall as low as sixty per cent or even less. Nowadays, school children in cities can usually obtain good seed in penny packages through educational centers. Fresh seed is generally easy to recognize by its bright, new surface. Peas are an exception ; even in their best days they may look aged and wrinkled.

It is part of a gardener's business to know how to test his seeds. There are elaborate methods which may be recommended, but simple rules will answer most purposes. Any 
child can learn how to take a given number of seeds and spread them in moist cloths between two dinner plates laid edge to edge. Then, by counting the sprouted seeds, he can get the percentage of germination. This exercise, by the way, makes a capital introduction to the study of percentage. In truth it would be hard to find a better.

A forcible illustration of how this exercise can be turned to practical account is contributed by a young girl of thirteen who has become so efficient in seed testing that she tests all the seeds used on her father's model farm ${ }^{1}$ covering about eight acres. As may be imagined, she is learning a great many things in the course of doing this very helpful piece of work. Some consider this the most effective sort of education.

Before beginning to test seed, it is a good plan, so they say, to examine it as follows : Weigh out three grams of seed, - onion, clover, or timothy, for instance, - and spread it on a sheet of paper. Then with a hand lens separate the seeds into three piles: in the first put the chaff, dirt, broken seed, etc.; in the second, all the weed seed; in the third, the good seed. Then weigh each lot, comparing the results. The good seed can then be tested as above for germination. Trying several samples of the same kind of seed from different sources soon teaches a gardener with whom to trade.

By the time the seeds have been tested, much labor will of course have been expended upon the land. First it has been thoroughly spaded; then the large lumps have been broken with the fork; and afterwards it has been raked over. Is the soil, then, we ask, ready to receive the seeds? Far from it; the gardener must not be discouraged at hearing that a creditable seed bed calls for a great deal more attention. In fact, the most irksome and, no doubt to his surprise, the most important task of all remains. This consists in picking out

I G. W. Field, Sharon, Massachusetts. 
all the stones, big and little, and in crumbling the last obstinate lumps. For a lump of earth, which invariably ties up a supply of food, may be regarded in the light of an investment. A perfectly safe investment this, but certainly not an available one ; and on that account many a plant, just for the need of a little ready food, may actually starve to death. Thoroughly crumbling the lump would have saved the plantlet's life. "Fining soil," writes an expert, "may be equal to fertilizing it." Indeed, the ideal soil texture has been described as resembling nothing so much as soft, black soot. Fortunately, if sufficient pains is taken, even very ordinary soil can be brought to that high pitch of refinement. It happened not long ago that some schoolboys listened with a good deal of interest to a discussion upon this subject, but shrugged their shoulders at the thought of descending to such petty methods. Still they did not feel quite satisfied without testing the matter for themselves. So they smuggled from home an old bread sieve and pulverized one little patch till the earth that passed through was as fine and soft as flour. Then they "raced" two sets of plants, growing one set in lumpy clods and the other in this superfine material. As a result the records of the second lot ran so far ahead of the first, in size and strength, as to make sifting all the rage in this school.

At last, through infinite pains, the ground, let us suppose, is right; the seeds are right; it only remains now for us to "put them in right." Just two points are to be kept in mind : the distance apart and the depth. There is, no doubt, a right depth for every seed, if we but knew it. For many of the commonest seeds experienced gardeners have worked out certain general rules, which, for convenience, are recorded in a planting table. ${ }^{1}$ The depth at which they are placed makes all the difference in the world to some seeds, while to other

1 See Appendix. 
seeds it matters far less. Nevertheless it is true, on the whole, that a shallow planting exposes seed to many dangers, not the least of which is the hunger of birds and beasts. On the other hand, to bury seed so deep that it decays before it can even begin to struggle to the light brings sure failure. And yet who is clairvoyant enough to know exactly what is happening underground? A simple contrivance that reveals many a secret of germination is the planting box with glass sides. ${ }^{1}$ Several seeds of the same kind can thus be planted at the same time and under the same conditions but at different depths, and their progress can be watched from. day to day. The best depth for many seeds will be found to vary from one eighth of an inch to one and one-quarter inches. Squash, for instance, should be planted one inch deep, lettuce. one eighth of an inch, while early smooth peas must go in four inches. A rule sometimes given is that the seeds which carry their cotyledons above ground, as in the case of beans or squash, should be covered by soil five times their thickness, while those, like peas and others, which do not bring up their cotyledons should be covered by ten times their thickness of earth. In deciding the question, however, the expert always takes into account such items as the character of the soil, the temperature, and the amount of moisture.

If rules for depth seem a little vague, it is equally difficult to give precise ones for the amount of seed to be sown in a given space. In spite of the pages of printed directions at the gardener's disposal, the quantity of seed used will, in a measure, have to be a matter of guesswork. Either of two extremes will plunge the beginner into extravagance. One extreme is to sow too scantily, the danger then being that when some seeds die, as they surely will, great gaps will stare him in the face, and the carth, left bare, will go to

${ }^{1}$ See Appendix, page 222. 
waste. On the other hand, although crowding seed seems the height of extravagance, this mistake, if taken early enough, may be rectified by a brave thinning. Where seed sowing is concerned, children are always prodigals. Nothing seems to shake them in the belief that if some is good, more is better, and neither the solemn warnings of their elders, nor their own fuzzy rows of crowded seedlings, where a plantlet has not half a chance, will cure them of this fallacy. Their illusions are destined to be shattered, however, when it comes to thinning, - for thin they must, reluctant though every youngster is to pull up a single one of his precious plantlets. It really does seem little short of heartless, considering that they have grown at our bidding, to root up the tender things. Yet, - comforting thought, — these same seedlings may be transplanted; and even when this is not advisable, they need never be a dead loss, for they can be tucked back into the earth bed and so contribute their mite toward enriching it.

The temptation to waste seed is lessened, and the percentage of failure in seedlings is reduced, by sprouting the seeds before putting them into the ground. Such preparation gives them a surer and a quicker start. Again, particularly in small gardens, seeds, instead of being scattered, will almost always be planted in drills, — drill being another name for a shallow furrow. With some seeds it pays to take even further trouble. A Lima bean, for example, laid on its edge with the eye down, far outstrips one which, dropped in hit or miss, must twist itself around.

Make the drills absolutely true by ruling them with the aid of a garden line and a sharp stick, or by pressing a hoe handle into the soft earth. The more precisely this is done, the handsomer the effect, and the more easily the plants are cared for. The distance apart for these drills depends upon the spread of the full-grown plant, both above and below 
ground. It is safest, on the whole, to allow ample room. Give rein to the imagination, remembering that, if all goes well, one wee, shriveled seed will make an opulent tomato plant.

Suppose that the drills have been of the required depth, that the seeds have been scattered or laid within at the proper distance, that the soil has been raked over the seeds without disturbing them and has been made firm by pressure; the next move is to pack them in tight. Accordingly tread, yes, stamp them down, or press them with a board. In case the earth is too dry at the time of sowing, it is a good scheme to fill the furrow with water, then lay in the seeds, crumbling over them some damp earth. Finally, pack them down as already directed, and make it a rule always to scatter along the surface of the row a layer of loose, dry earth. Do not leave the spot without marking it clearly with a wooden or a metal label telling the name of the seed and other data. This is more important than one might guess. The habit of careful labeling prevents many an awkward mistake, and it makes a garden far more interesting.

All the planting, of course, will not be done in the open. Many sorts of plants can be started under cover, anticipating the season by a month or more, and at the right time they can be set outdoors. Everything that can possibly masquerade as a window box or pot will now be pressed into service. Tin cans and cigar boxes suddenly rise in value. Whether indoors or out, the use of various sorts of glass covers to prevent rapid evaporation will be found indispensable.

Some of this preliminary planting, besides, is often done by young people just by way of experiment ; they want to try new ways of testing seeds, of growing them at different depths, and of starting them in different materials. Some attention will unquestionably be given to preparing a little nursery of seedlings for transplanting. Indeed, one can seldom have too 
many seedlings, especially if one likes to exchange, or to share with neighbors who have not been so forehanded. Here it is that an older person often has it in his power to turn, by a chance word, the current of thought of his young friends in one direction or another, by stimulating what is called idle curiosity so that it develops into a true scientific spirit.

Much of the technic of planting can really be learned indoors; the principles will then need to be applied on a larger scale to the conditions outside. Even the simplest window boxes call for well-prepared soil and for a knowledge of how to put in seeds and how to water them. In these the question of drainage is something of a puzzle. To arrange this indoors naturally requires special contrivances. It is usually secured by simply making a few holes in the bottom of the box or can. These holes are covered with flat stones, so that the earth will not sift out, and the entire bottom is then spread with a layer of pebbles, earthenware fragments, and bits of charcoal before filling the box with earth. Cigar boxes, strawberry boxes; and the like will obligingly leak enough to drain properly.

Growing under glass is a fascinating occupation. In these days some knowledge of the methods now employed is part of the equipment of every gardener. Within fifteen miles of Boston, for example, the enormous space of more than two million square feet of glass, or over forty acres, is devoted solely to vegetables. It pays at the not insignificant rate of fifty cents per year for every square foot.

Culture under glass aims to copy nature at her best, so it will be arranged that the frame shall bask in full south sunshine and be protected on its north side. The very simplest form of growing under glass is the cold frame. Just a single large pane fitted into the top of a box, which is to act as a temporary protection for a few plants, will do as a beginning. 
The first cold frame, for instance, used in the Boston school gardens was made of planks nailed together to support a window sash three feet by six. This old double window belonged to the schoolhouse and had been lying discarded for years in the basement. Suitable soil was made by mixing loam with barnyard manure. Several hundred plants were easily grown here at one time, and there was space for many

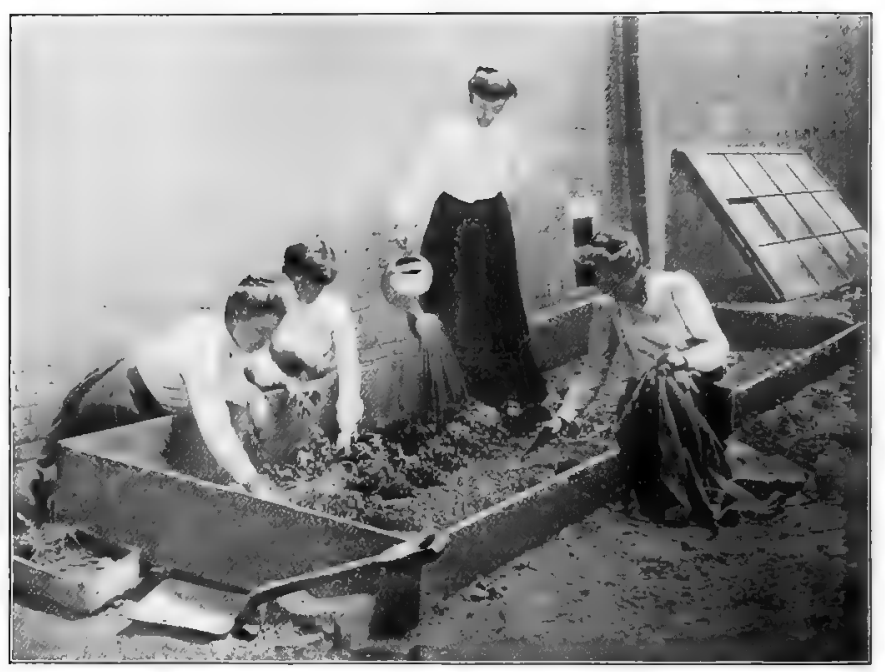

NORMAL-SCHOOL STUDEXTS WORKING AT THE COLD FRAME

more seeds. In the frame were started different kinds of early vegetables; and these got under way a good month before the weather permitted planting outdoors. Lettuce, cabbage, tomatoes, spinach, and parsley throve here beautifully. By the time these had made a good start and had been pricked out once, - in other words transplanted to other boxes, - it was mild enough to transplant them to open ground. Needless to say, it was worth the trouble. 
The simple routine necessary in caring for a cold frame is easily followed. The slanting sash should be lifted a little while each day to secure ventilation. A thermometer hung inside the frame registers the temperature, which will be kept always near summer heat. This gentle warmth is furnished by the decomposition of the manure that has been mixed with the soil, as well as by the sun's rays, which pass through the glass but are prevented by the glass from radiating.

One year's success with a cold frame tempts a gardener to try a hotbed. This is not so difficult a matter as a beginner might suppose. A little skill, to be sure, is required to control the heat, which in this case is furnished by fresh stable manure. In the fall the gardener mixes the manure with straw, piling it in a dry place to let it ferment. Later he forks it over several times. When he starts his hotbed, he spreads this dressing so that it will partly fill a shallow pit somewhat larger in area than the wooden frame, packing it down hard and spreading on more until it has reached a depth of two feet. He then sets down the rectangular frame, forcing the sides into the dressing until it stands firm. Within the frame, which is built at least a foot higher at the back than at the front, to give a good slant to the glass, he places a layer of dry leaves or straw. The reason is obviously to separate from the dressing the layer next above it, which is to consist of rich soil. This soil is now spread on layer by layer. It will be at least six inches thick, so that the seeds will not be in danger of touching the hot manure. The thermometer, we will suppose, has been pushed down a little way into the soil as a telltale. This must be constantly consulted, for it is necessary to know the amount of heat that is being generated. The temperature before planting begins should be steady, ranging between sixty and eighty degrees Fahrenheit. If it runs higher, some safety-valve holes must be made 
in the earth to let the superflious heat escape. If it runs below, more manure must be added. Hotbeds are often expensively built and elaborately heated; but a plain frame costing nothing but the labor, provided one has stock and some pieces of glass, often works wonders.

Whether one is specializing in vegetables or flowers, a gardener will always do well to save a little space for bulbs. Bulbs will glorify any sort of garden. They allow themselves to be tucked so conveniently anywhere and everywhere, into the corners of a kitchen garden, dotting a lawn, or along the curbstone of a little front yard. City people will walk a mile and more to see the first purple and yellow crocuses springing up on a March day from beneath the patches of snow. To say that raising bulbs is easy sounds overconfident, but as a matter of fact bulbs only insist upon having rich loam, good drainage, and a little judicious care. Failure to make them succeed may pretty surely be traced to the neglect of one of these conditions.

Late September is the time for setting out winter bulbs. It is wise to line the holes with a little sand, to prevent the earth from getting soggy and thus rotting the bulbs. In order to keep them snug and warm during the winter, pile on mattings of straw, or boughs, or leaves. Then in the spring remove the wrappings, but not too suddenly. Bulbs may be left in the ground throughout the year to flower each spring during successive seasons, provided the space is not required by other plants. If the room should be needed, however, store them and later set them out again. When once established, they multiply at a great rate, growing in spite of all sorts of drawbacks, so that your stock is bound to increase. No plants yield more lovely blossoms for the house. For this purpose they may be grown in almost anything that allows good drainage. 
House-grown plants from bulbs are treated according to the same general principles as those outdoors. After they have been put in pots or boxes they pass their resting stage in a cold, dark part of the cellar. Some of these will be brought out into a warm, sunny room early in December, in case they are to be used for Christmas. But newly started bulbs should be "hardened off " in partial light and in a cool room before being placed in the sun. Keep back the others so as to have them flower in succession.

There is often a good profit in raising bulbs for private sale. In Boston one of the events looked forward to by many lovers of plants is the annual exhibit of hundreds of bulbs raised by a woman who makes bulb growing a specialty, and who devotes the proceeds to charity.

Out in the garden the crocus, daffodil, hyacinth, and freesia may all be cultivated successfully. Explicit directions for the special treatment that each requires will be found in the catalogues. Every gardener will, of course, have his favorites; but the beauty of the rest certainly dims beside the glorious flames of the tulip. Another bulb of rare beauty which blooms in the summer and autumn, and one which is a stranger to some gardens, is the gladiolus. If gladiolus bulbs are planted at intervals from April to June, the plants will flower as late as November. When their flexible stems are supported by wire or stakes, they stand the early frosts bravely. The gladiolus is one of the plants which, within a few years, has begun to delight flower growers with its matchless beauty. One stalk of exquisite blossoms will sometimes sweep through nearly a whole rainbow of color. A very practical reason for their popularity is that the bulbs may be bought by the hundreds at very reasonable prices. The canna and the dahlia also flower superbly in summer and autumn. These do not grow from bulbs, but from roots; and they propagate by root 
division. Late spring is the time to plant. One hint to those who cannot make room for a bulb bed or border: Try planting crocuses and scillas in the grass, even under trees. Make little holes with a crowbar or pointed stick, and set them out by the hundreds. They look lovely against the background of green.

The sequel to planting is transplanting. Success depends upon many of the conditions already mentioned, and upon still others that will be discussed later. 


\title{
CHAPTER VII
}

\section{THE ART OF MAKING THINGS GROW}

\author{
Good tilth brings seeds ; \\ Ill tilture, weeds. - TUPPER
}

The easy assurance of this phrase may possibly suggest a get-rich-quick scheme, or a proprietary medicine. But we know very well that the expert has learned by experience many a short cut to successful gardening. Moreover, he is only too glad to pass along his devices to any young gardener who will stop long enough to listen. These devices sound trivial enough in themselves, but they usually connect with some established agricultural principle. They remind one of electric wires, which are of little use unless they can establish connections with the central dynamo.

Perhaps there is no time when a friendly hint is more appreciated than when the first planting of one's first garden is finished. The rush is over; the seeds lie snugly tucked in the ground; and over the surface a thin blanket of dry earth has been lightly spread. Taking a last look at his work, the young gardener involuntarily draws a sigh of relief. This says as plainly as words that he considers his part of the contract fulfilled, and that now he depends upon Madam Nature to do hers. This attitude is quite common to beginners; we are not all so frank, however, in acknowledging it as the young girl who had been brimming with enthusiasm in getting her garden under way, but who, a little later, wrote to a friend that she had finished planting, and that since then there was really nothing for her to do; she was waiting for her plants 
to grow. An old hand would consider this a great joke; he would be tempted to remark that if her idea was to bury seeds and then simply linger about, her best crop would consist chiefly of great expectations.

Experienced gardeners take this matter very seriously and have a great deal to say about the care of crops at this stage. "Tend the crop as you would tend pet animals," says one. "Water and stir the soil as untiringly as a cook does her kettle" are the words of another. But the bother of it! And after all, what difference does it make? The gardener answers that the surface of the land hardens and crusts over if it is left untended. A hard soil that has begun to cake effectually blocks the progress of the delicate seedlings which are trying with all their might and main to push their tiny heads through. More than this, it does not offer at all the right consistency for soaking up rainfall and dew. Soil, above all things, should be porous and spongy. If it fails in this, the water (except, of course, in case of a heavy downpour, when the earth cannot help getting drenched) quickly drains off into the hollows, where it settles in puddles. In the meanwhile the thirsty roots remain high and dry, and the water, all too soon, evaporates and becomes nothing but a memory.

Now roots have a wonderful way of seeking their water supply. In whatever direction water may lie, their tendency is to grow toward it. A deep source is an advantage, for the deeper it is, be it natural or artificial, the more unfailing will probably be the reservoir. The turn roots take, therefore, is closely connected with the method of watering. Thorough soaking means deep-striking. roots, while surface watering means shallow roots. This latter method of treating soil suits weeds to perfection; they want no better invitation. A multitude of tiny seeds, as we know, are always lying dormant in the dressing. Others, perhaps, have been flying with the wind 
and meeting a shower have been caught for the moment in the fresh damp. Now weeds are famous surface growers; in the twinkling of an eye they strike root. At all events they make far better speed in getting above ground than most of our carefully planted seeds. The little beggars seem to understand, too, that at this stage, where so many tiny green shoots are just peeping up, a garden ignoramus will get bewildered and will not be willing to risk pulling them out. So they get at least one day's grace. They have gained their point, and a fight with the pesky things is on.

A gardener who means to win must use strategy. A true diplomatist therefore covers the ground with a sort of dust blanket or mulch. This is accomplished by gently stirring or pulverizing the surface as often as possible. Such treatment checks weeds, inasmuch as it takes the ground from under their. very feet. In a big garden this is done at stated intervals; in a little one, nearly every day. A blanket of this sort also protects the earth and enables it to conserve the precious moisture. So long as the earth looks wet, the moisture is pretty sure to be slyly escaping. Prevent this by spreading on a dry powder, and presto! evaporation stops.

Now water acts according to the laws of capillary attraction in the soil just as it does in a lamp wick or a lump of sugar. A simple experiment illustrates perfectly what goes on in the ground. Take a lump of sugar, lay on top a pinch of powdered sugar, and dip its lower end in water. The water will creep up through the lump, but no farther. Even after the lump is saturated and has begun to dissolve, the powdered sugar remains dry. Color the water, and its progress is even more noticeable.

This stirring process is technically known as cultivation. Its value to the garden cannot be overestimated. Through its practice three important things are accomplished: It kills 
the weeds, to begin with; then it keeps in the moisture; and, besides, it airs the soil. So, since the roots of plants cannot work without oxygen any more than their green parts can, it is well to "stir some" into the soil.

On farms the work of cultivation is so extensive that it must be done by horse power. For small fields a wheel hoe or cultivator is used, which runs handily between the rows.

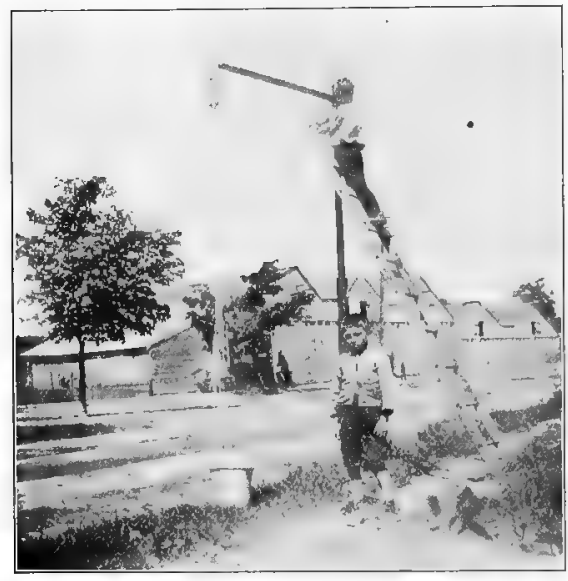

GUMPTION A children's garden is kept well groomed, as it were, by an excelsior weeder or even a skewer, supplemented from time to time by the deeper stroke of the hoe. The expression "watering with the hoe" is a common one and, after what has been said, needs no explanation. A matter for congratulation is that the practice of cultivation, or dry farming, as it is practiced to-day, relieves the gardener of what has always been a perfect nightmare to him, - a season of drought. It may be added that abnormally arid districts should hardly be selected to illustrate the advantages of dry farming. After all, the whole philosophy may be summed up in the gospel of the parson who, urged by his congregation, prayed fervently for rain, but who closed his petition thus: "Send us, we beseech thee, rain; and yet, $\mathrm{O}$ Lord, thou knowest that what we really need is not more rain but better plowing, deeper tillage, and more top-dressing." . 
Understanding the science of watering, and applying it in action, does not necessarily mean that our old friends the watering pot and the hose must be laid on the shelf. Indeed they still retain their places. But a beginner sets far too high a value upon them. What is more, he does not use them properly. A "greenhorn" betrays himself at the first garden lesson by the way he handles thesearticles. We have all seen him as he stands at noonday in July complacently sprinkling his poor little half-burnt greens, sublimely unconscious of the fact that the rivulets are trickling off into the paths instead of sink- . ing down into the earth.

One of the best children's gardens I know owes its success, after an exceptionally dry season,

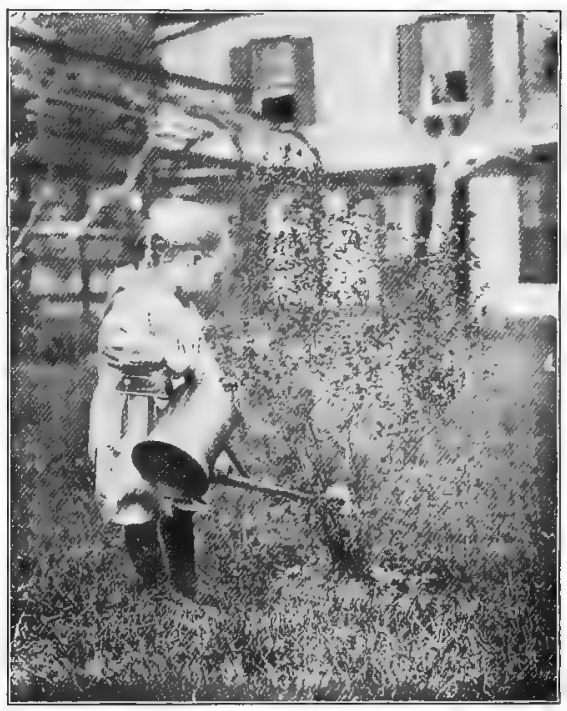

A GOOD LONG DRAUGHT to the constant and thorough cultivating which it received, and to the exclusion of surface watering. "No water was available," says the director, "but the gardens, although on a sunny slope, withstood the droughts well, save in a few neglected plots. These furnish a forcible illustration of the value of cultivation for the conservation of the moisture in the soil." 1

${ }^{1}$ Miss Grace L. Sturtevant, Wellesley Townnsman, October, I908. 
An inexorable garden law is, Never sprinkle. What the earth craves is a thorough soaking, so that the moisture will sink down far below the roots. The time to water is early in the morning or in the evening, not in the blazing sun; so goes the good old rule. An expert gardener, however, who is less bound by tradition, writes: "Water at any time that the plants need it, only water thoroughly. When I am told that watering under a noonday sun will burn up my plants, I answer that my plants will certainly burn up if I do not water them." This piece of advice is certainly comforting to the school gardener, who may live some distance away and who often finds it impossible to devote early morning or sunset hours to the work. The point, however, upon which everybody agrees seems to be that the wet surface must be promptly mulched with dry earth.

The mulch so often spoken of should be spread not only over newly planted ground but around plants at all stages of their growth. It frequently happens that the mulch put at the base of young shrubs or trees consists of sawdust or coal ashes. Weeds would certainly find cold comfort in a mulch like this. In truth, such materials are pretty nearly weed proof. Whatever the substance, however, the purpose is always to keep the soil in prime condition, ready for taking in moisture but not for parting with it.

In connection with watering, a word may be said in favor of a plant tonic which gives excellent results and yet costs nothing. This is a liquid preparation of ordinary street manure, which is put into a jar or tub and covered with boiling water; after cooling, it is thinned to the color of tea and used freely for watering. Under this treatmefit, plants shoot up quickly and vigorously.

Irrigation, as we know, is the wonderful means by which farm lands are made independent of rainfall by being supplied 
with water in trenches. It is not so modern a method as some are apt to think; indeed, it seems to have been well understood far back in early Babylonian times. The way in which vast tracts of country in the great West; as well as in foreign countries, have thus been made richly productive is little short of miraculous. By irrigation deserts have been transformed into veritable gardens of Eden. By dint of courage and skill men have learned to harness up streams of water, and to drive them at will through pipes and ditches for the service of mankind. In Italy, near Milan, there is a famous example of how thousands of acres have been reclaimed by means of water conveyed by irrigation from the sewers of the city. These meadows were but yesterday desolate wastes; now, quickened into life, they yield from three to nine times the crop of ordinary fields.

Fortunately the reclaiming of waste lands is to-day, as never before, attracting attention. Among these are dunes, salt marshes, and barren islands. Marthas Vineyard is a good example of a hitherto neglected opportunity. At present the chief occupation on the island is shooting. The cultivation has been meager, so that nearly all supplies are brought by boats from the mainland, and yet there are ponds lying in the southeast portion of the island which could easily be used as a basis for irrigation. It is certain that irrigation, combined with the wonderful climate, would make of this island a second Jersey or Guernsey.

Of course a young farmer who lives near a town or city and has the water department and a few feet of hose at his command will hardly need to adopt any system of irrigation in order to save his small domain from the perils of drought. Even so, why not test for one's self the benefits of a new scheme, which, it is claimed, will more than treble the old returns? As a matter of fact, within a very short time 
experiments in irrigation have been tried in small gardens and have given such splendid results that even for tiny spaces the method is becoming more and more popular. In one city yard a clever arrangement of draintiles was devised by some girls at home to secure water control. Even though so roughly carried out, they considered the attempt a success; but at last accounts they were still at work trying to improve their scheme. Such adventures help other explorers. Moreover, they train a person's intelligence and fit him to comprehend the big present-day problems of our wonderful country.

When it comes to transplanting, success is largely dependent upon a knowledge of the principles of watering. Any one can go through the motions of transplanting, but few can make every plant grow. The morning after is apt to reveal many a flat failure. Young gardeners who have sometimes met with poor luck will welcome a few practical hints. Begin the process by removing each plant with as large a ball of earth around its roots as possible. Trim off about one third of the top, so as to diminish the leaf surface and thus check evaporation. Set it well into the damp earth, spreading carefully any rootlets that straggle. Fill in now with earth and pack the whole down well; the plant should not loosen at a gentle pull. Give it a sip of water at this crisis, if it looks thirsty. If this is a case where growth is to be hurried along, the water used may be some form of liquid manure or a solution of nitrate of soda. Add as the finishing touch a covering of mulch. A young seedling is usually old enough to transplant when it has attained the dignity of from four to six leaves.

Do not be tempted to transplant in the open sunshine; as sure as fate the sun will evaporate the water through the leaves before the roots get into working order. The best time for transplanting, as for watering, is in the early evening or on a cloudy day; but busy folks cannot always choose, and plants 
cannot always wait, so if a gardener is forced to do this when the sun is high, he may be consoled by remembering that there is always "some way out." It is quite an easy

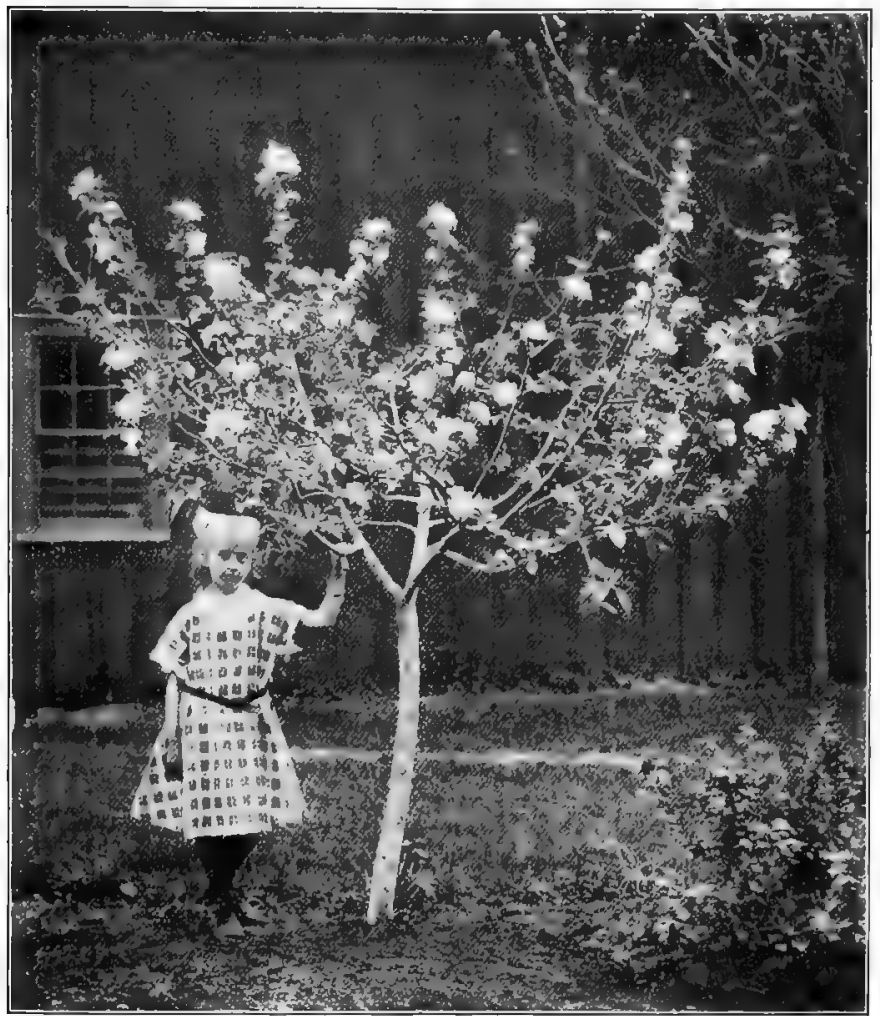

TRANSPLANTED

matter to supply sunshades for the newly transplanted seedlings; an inverted flowerpot will answer. Children frequently make cocked hats out of paper or pasteboard, which can be held in place by pegs or by a couple of clothespins. Even a 
shingle stuck in the ground on the sunny side of a plant will cast grateful shade, to which it may owe its life. In a word, use every ingenious means that suggests itself to guard against the loss of moisture by evaporation between the time of taking up a plant and that of resetting it. Few realize that little seedlings get limp by sheer exposure to the wind. Lay over them, therefore, a dampened cloth as they lie waiting in the heat or in a draft.

There is a noticeable difference in the ability of plants to stand the shock of a change in position. Tomatoes, cabbages, and lettuce are among those sturdy ones that may be depended upon to transplant well. Tomato seedlings lead a charmed life, _ you simply cannot kill them; but other plants, such as the cucumber, squash, pea, and morning-glory stubbornly refuse to prosper. Nevertheless, even these capricious plants will sometimes yield to coaxing, provided they have been started in some small receptacle like a berry basket or paper flowerpot, which can be broken away without wrenching their systems. A class of children one year started some lettuce seed in eggshells. These fragile cradles, though so tiny, proved in every way satisfactory, for a gentle squeeze was enough to crush the shell as the plant was being introduced into its new home. Was it not the custom of Mrs. Thaxter, the ardent friend of children and of flowers, to raise in eggshells the seeds for that beloved garden of hers at Appledore?

Shrubs and trees should be transplanted according to the principles just described, except that the season for their removal is restricted to autumn and spring. Stout roots cannot be torn from their home at the height of their activity and still live; but after the period of active service is over for the year, or before it begins, if treated kindly they will not suffer.

As for small fruits, a strawberry bed is most practical, while currant, gooseberry, and raspberry make themselves 
perfectly at home in school gardens. One or two plants of each kind are enough to practice upon if lack of room prevents having more. Every one of these shrubs, however, rebels against shiftlessness and will not put up with neglect. Space must also be saved for a few fruit trees. Nobody can be blind to the advance that is being made every year in the abundance and perfèction of American fruit. Much of our best fruit is sent across the water, and our fruit farms are the admiration of visitors from abroad. A miniature orchard will give young people a chance to learn some of the secrets of practical, up-to-date fruit culture.

The nurseryman sets out his trees and shrubs early in April. Accordingly, by that time the trenches

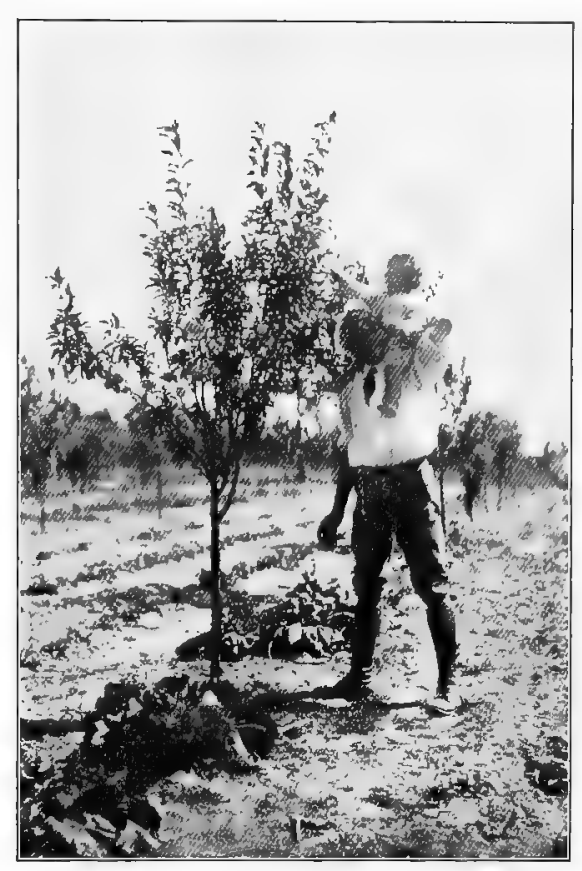

A FUTURE ORCHARDIST must be ready and waiting. A little tree requires a trench at least three feet wide and two feet deep. The gardener begins by filling the bottom of the trench with earth; this he fairly saturates with water. Next he brings out one by one the treelings, whose roots during transportation have been kept so carefully wrapped in damp matting or straw. They 
should be given more water at intervals as they are being set into place. When the trench is filled, he treads down the earth with his whole weight; and when all this is done, he mulches the plants with straw or leaves. As soon as time permits, the branches must be trimmed. It will not do to make the mistake of pruning in summer when the sap is moving; and it must be remembered that an evergreen tree cannot be pruned oftener than once a year, and that in the spring.

Every one speaks a good word for shrubs. For purposes of decoration they will be set out either singly or in clumps, seldom in rows. They will act, too, as a windbreak for some bed of tender plants. Again, they may be set out in order to give a bit of seclusion to one corner of the garden. A hedge of flowering shrubs proves the neighborhood's delight. The only difficulty is in choosing from such a great variety as is offered. All gardeners have their favorites. Some sing the praises of the Japanese quince, which certainly does border a garden charmingly. Others think nothing equal to the Tartarian honeysuckle, especially the lovely pink flowering sort, and it is true that, whether in blossom or in berry, it is always superb. Forsythia finds favor as a hedge ; the plant keeps its leaves till cold weather. It pays a garden maker to study how to mass shrubs so as to secure happy effects. Not everybody can paint pictures. Fortunately, those who can use a brush and colors are not the only artists in the world; some persons truly succeed in becoming "artists in things." Many a person can educate himself to be such an artist; by watching colors, forms, and shadows he can really create beauty in a garden by means of his plants.

When all is said, it may still seem as though some persons were wizards in the sense that they can stick anything into the ground and make it flourish. Perpetual good luck, 
however, does not visit any garden by mere chance; to a discerning person it is clear that success comes to those gardeners who make much of their children. Plants grow for those who love them; they fully appreciate petting. They cannot purr, indeed, but they respond gratefully with blossoms and fruit. A watchful eye, constant care, - in a word, devotion to their needs, - is the magic touch which makes things grow. 


\section{CHAPTER VIII}

\section{JUST HOW}

There is a best way of doing everything if it be to boil an egg. - EMERSON

This is the title of a little cookbook which was published in the early seventies. It was the first of many primers of cooking designed for the young housekeeper who was paralyzed by the elaborate recipes that weighed down the ponderous volumes of that day. To the inexperienced young cook who did not aspire to such creations as, for instance, the Duke of Portland plum cake, this book proved a real godsend. It condescended to explain how to beat an egg, (there is, it appears, a best way to beat an egg, as well as to boil one) and how to make dip toast. By the time she had "passed her preliminaries " by the aid of this modest volume, the young housekeeper had acquired enough skill and confidence to advance by sure and easy steps to higher triumphs in the culinary art.

This chapter undertakes much the same mission in its own small field, which is to explain in minute detail certain welltried recipes for raising a few common vegetables. It is true that library shelves are filled to overflowing with manuals on gardening, and every packet of seeds is covered with directions; but these directions, while plain enough for the experienced, have often been the despair of the beginner. For is there a beginner who does not occasionally long to have an old gardener standing at his elbow, reminding him by a friendly word not only what to do, but, — far more to the purpose, - 
what not to do? Having once succeeded in bringing to perfection his first ten vegetables, a novice learns to interpret many signs in the life of plants to which he was blind before. There is no reason why the ten vegetables here discussed should not be successfully grown during a garden's first year. Even a still larger number could of course be tried, but too little rather than too much is always a safe rule.

Beans. There is no more wholesome and popular vegetable than beans; a plentiful supply should be raised in everybody's garden. There are ever so many varieties; among the commonest are string beans or snap beans, - the entire pod being edible, - besides wax, Lima, and pole beans. The scarlet runner is also a pole bean and is often grown as an ornamental vine, but its beans are desirable as shell beans. Almost all kinds of beans are now raised in dwarf varieties. The following hints are applicable to their culture in general.

Beans are, on the whole, hardy and easily grown. The only possibility of failure would lie in planting the seed before the soil is warm and dry, for beans are warm-weather thrivers. In the north the middle of May is early enough. They like rich, moist soil, in contrast to a poor and shallow one, and need every ray of sunshine they can get. Give them always an abundance of light and air; plenty of moisture too hastens growth. This method makes the beans deliciously crisp; grown slowly, they are likely to be tough and tasteless. The pods should be ready to gather in twelve or fourteen weeks. There can be several plantings. The first three can be made on ground from which there has been harvested spinach, early radishes, or lettuce; after that, on ground from which there will have been taken peas, potatoes, and beets. If the school gardener can raise only one sort of bean, let it be string beans by preference, though it would even then be instructive to ripen a few shell beans. 
Beans belong to the family of legumes; so, as may be guessed, they are nitrogen gatherers. Consequently they are best stimulated by a fertilizer that contains little or no nitrogen but chiefly phosphoric acid and potash. Their greatest enemy is rust, a fungous disease. This is troublesome at damp seasons; therefore be careful not to brush against the vines when they are wet, lest the tiny fungus should be sown on the leaves. Pinch off the ends of the plants if they are growing too fast, so that their strength shall not run to foliage.

The bean chosen for baking is a variety of pea bean. It is prepared for the market by a special process. When appearing on the table after hours of slow cooking, a dish of Boston baked beans should be about the color of a horse chestnut, and of a mealy consistency, although each bean keeps its own distinct shape.

Beans, both shell and string, are commonly boiled. Beans that are boiled are served with a seasoning of salt, pepper, and butter, or covered with a cream sauce. Cold boiled beans make a delicious salad. They should never be put on to cook in tepid water, but, to keep their flavor, they must be covered with boiling salted water.

Beets. Beets are grown for two purposes: for their tops, which make tender greens, and for their thickened roots. They are hardy and of easy culture. Turnip beet tops will mature in two months or less, and the little new beets are ready by midsummer. The soil should be rich and light.

Beet seed should be scattered thinly in drills a foot apart. These so-called seeds are really fruits containing several true seeds, so that the plantlets come up in queer little clumps. This explains why they require special thinning. Sow seeds as early as the ground can be worked, and again every two weeks up to the end of July. The depth for planting in the spring is one inch. Constant cultivation is necessary for a good crop. 
Beets do best when thinned twice. Thin first when the plants are about five inches high, or even less, leaving spaces of three inches. The second thinning leaves a distance of about six inches. These seedlings will be used as greens. At the second thinning, young beet roots will be pulled up as well. These whole plants are therefore served as greens; it is hardly worth while to transplant the thinnings. Beets are subject to scab on the roots and to rust on the leaves.

Table beets may be boiled, stewed, creamed, or pickled. In boiling, be sure not to break the skin. Put them into boiling water and cook slowly for one hour; then drain and the skins will slip off. These boiled beets are to be sliced and seasoned with salt, pepper, and butter. They make, too, a favorite pickle.

Cabbage. Cabbage makes an excellent and wholesome food. It is widely appreciated too. Market quotations show that thousands of tons of cabbages are consumed every week in a great city like New York. It is said that nobody knows what a delicious flavor a cabbage may have until he picks one fresh out of his own garden. A gardener, if he likes, can have a supply of cabbages the whole year through. To raise very carly cabbages, plant seeds indoors in February. Prevent them from growing tall and spindling by giving extra sunshine and by pinching them back. In the cold frame, seed for a second lot may be planted as early as April, provided it is sheltered; by the end of June the seedlings will have grown large enough to set out. These ripen by November. Still a later variety can be set out in July. In a small garden, where space is precious, it is advisable to choose the late cabbages. Then other vegetables will have had their chance, and the cabbages may take all the room they please. Such handsome ones as the expert likes to produce cannot ripen properly nearer together than two feet. In case the seed is sown out of doors, 
the distance between drills should not be less than ten or twelve inches. One foot of drill will give about two dozen seedlings. Seeds are planted one-half inch deep.

When the seedlings are ready for transplanting, pinch back the leaves, for it is necessary that the roots should get established as soon as possible. Do not hurt the central shoot, for that would spoil the leafy head. Set each plant in a little deeper than it stood before, so that it will not topple over from its own weight.

There are three varieties of cabbage: red, smooth, and wrinkled. The picturesque purple cabbage fields that one remembers seeing everywhere in France are made up of the red. The smooth are most common in our country, though the wrinkled are said to have the finest flavor. All varieties call for generous manuring. Poultry manure may be used in part. More than most vegetables, cabbages need patient culture, so that they may be supplied with steady moisture.

Cabbage enemies are numerous. The most disagreeable ones are the cabbage worm, the loopers, and the flea beetle. There are, besides, two mischievous fungi that attack it: black rot and club root. The insects must be picked off or sprayed with poison. Watch especially for the pretty but dangerous little cabbage butterfly. As to the fungi, if they persist they must simply be starved out; so burn all the leaves that show the fatal signs. Burn whole cabbages if necessary. Examine every plant carefully before storing for the winter. Cabbages are amazingly hardy; they need not be stored earlier than Thanksgiving. Then pack them in a shallow trench lined and covered with hay, and pile on some earth.

Americans have much to learn from cooks in other countries about the use of cabbages, particularly from the Germans, whose bill of fare is hardly complete without some cabbage dish. They have many recipes which can easily be 
obtained. The famous sauerkraut is probably the best known, and to most Germans it is unexcelled. There are also cabbage pickles in great variety, besides cold slaw or a salad made of the leaves finely shaved and served with a dressing which, by the way, is improved by plenty of mustard. There must not be forgotten, besides, the plain, homely, workaday boiled cabbage which is always welcomed by a hearty appetite.

The student of botany will find it a good plan to allow one or two cabbage heads to last over till the second season, in order to collect some of the seeds that are developed in the yellow flowers borne in a tall flower stalk three or four feet high.

The cabbage tribe is a large and most important one. All the branches of the family, produced as they have been by careful cultivation, are worthy of attention. Each has its own distinctive characteristic as an article of diet. Cauliflower has perhaps attained the most delicacy. Who, by the way, has spoken of it as "cabbage with a college education"?

Carrots. In England and France carrots frequently appear on the table and are esteemed so highly that they are often grown under glass. Their virtues are becoming every day better appreciated in America. Carrots and parsnips require about the same treatment and are often planted at the same time, although the carrots are harvested first. They are very hardy and attract almost no insect or fungus enemies.

The earth should be dug deep, for carrots have long roots; sow seed thick and as early in the spring as possible, planting it one-half inch deep in rows about one foot apart. It grows very slowly, so that a crop of radishes may be sown on top and skimmed off the ground, as it were, before the carrots need the space. In fact, radishes actually help the growth of carrots, since they break the soil for this slower crop. 
Keep the bed of carrots free from weeds, so gardeners say; therefore cultivate carefully and do not let the earth harden. Thin to a distance of four inches. This spring sowing will secure early carrots in June. Late carrots are sown at the end of May or early in June, and these will keep through the

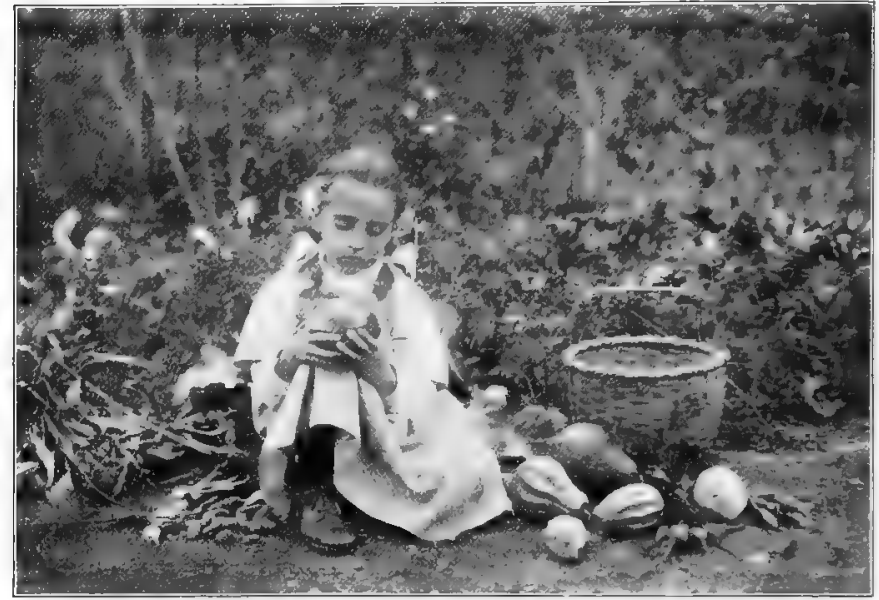

SELECTING FOR MARKET

winter, either in sand in the cellar or in pits in the garden. These early carrots, however, must not be expected to last through the winter.

Young carrots are appetizingly prepared in this way : Boil in salted water till tender, drain, and serve with drawn butter. If you please, they may be cut into dice. They are sometimes served acceptably with peas; the contrasting colors certainly make a pretty combination. The carrot leaf is finely cut, of a lovely bright green, and it can garnish a dish very effectively. Some persons enjoy pickled carrot.

Lituce. Lettuce is perhaps the favorite regetable for a small garden. It is coming more and more into demand. 
There are two main types : one tall and narrow, the cos; and the other low and spreading; the cabbage. It is a sturdy plant, and it can be planted as a companion for some other crop radish, for instance - or as a succession crop. Seedsmen distinguish between white- and black-seeded lettuce; the former is grown chiefly by forcing, the latter, out of doors.

The earliest crop of lettuce is always started within doors, and is either set in the ground or allowed to mature in glass frames; but as soon as the ground is in any sort of condition for planting, the first outdoor sowing may be made. Lettuce transplants well; manure is its best fertilizer; its pests and diseases fortunately cause gardeners very little worry.

Lettuce will grow obligingly in any good garden soil, but the best results are to be had with earth that is light, warm, and quick.

Under glass or in the house sow lettuce in drills a few inches apart; prick out, when the second leaves appear, to four inches apart. Repeat this as often as it seems necessary, until the plants stand about one foot apart. The depth for lettuce seed under glass is one-quarter inch, and in the open, one-half inch.

Here are some special hints for the raising of lettuce : Cultivate constantly and keep the leaves free of earth. Be careful not to hoe against the plants so as to mar the leaves, and do not let any fertilizer touch them. The cos lettuce must have its leaves drawn up and tied at the top in order to blanch the hearts.

Pick the crop as needed. It is best done in the early morning, while the leaves are crisp and before the sun has had a chance to wilt them; then place the plant in a cool, dark place, with its stem in water. An hour or so before serving, the leaves should be pulled apart and washed thoroughly in cold water. After the water has been well shaken off, the plant 
should be tossed about for a moment in a piece of cheesecloth or mosquito netting. Then lay it directly on the ice. The delicious crispness and coolness of prime lettuce cannot be equaled; indeed, its food value lies largely in its refreshing qualities. Lettuce is the chief constituent of most salads; eaten with an oil dressing and a dash of vinegar, not too much, it is considered most wholesome. There are several varieties of lettuce which are now only slightly known in America, but which could easily become popular; their flavor, according to the taste of many persons, is superior.

Onions. Onions have the name of being one of the best stimulant vegetables known; they deserve to be even better appreciated than they are. Onions are bulbs; they may be grown from the seed or from onion sets. Sets are baby onions, formed by division of the parent bulb. Growing onions from the seed requires very careful handling, for the seedlings are mere wisps; this makes prompt cultivation most important, because if weeds once get the right of way, it is almost impossible to kill them. In this case a steel rake loosens the earth well, for it allows the seedlings to pass between its teeth. Seeds may be sown in a box indoors in January or February. The plants must then be pricked out into deeper boxes and finally planted in rich, firm ground at the end of April. They will be ready for harvesting by the end of August, when they should be drawn from the ground and thoroughly sunned.

A more satisfactory method, however, is to plant the sets. The first year they can be purchased from seedsmen. Onion sets should be put into the ground at the earliest possible moment, and the bed reserved for them must be as richly prepared as possible. W'ell-rotted manure, poultry droppings, bone meal, and wood ashes are sometimes all dug in together. Plant the sets in rows about six inches apart. Put them in just deep enough for the green top to show 
above the surface; then firm them well. This is the way to get early onions, a real spring treat.

Root maggot is the most troublesome enemy of the onion, but it is also attacked by leaf blight and smut. Any part that becomes affected by these parasites should at once be removed and burned.

The unintelligent cooking of onions is partly responsible for their unpopularity. Onions contain a volatile sulphurous oil which will in a measure disappear if this rule is followed in preparing them: Wash them, cover with boiling water, then cover tightly and boil for ten minutes; drain, cover again with fresh boiling water, repeating this process twice more, making four times in all; add a little salt and boil till tender, keeping them covered all the time. When finished they should be dressed with a cream sauce.

Parsley. Parsley is a dainty little plant, grown for its curly leaves. These are used for garnishing and for seasoning, and occasionally in salads. One curious thing about growing parsley is that a person may easily be deceived as to the success of the seeds planted, for they are extremely slow in germinating. Sometimes after their coming up has been despaired of, it may be after four or five weeks, all at once they delight us by appearing. While waiting, however, do not be tempted to let the earth cake over the seeds or to dry up. As for soil, parsley only asks for good medium soil worked deep and fine. Sow in protected nooks, or as a border for beds, or, as is more usual, in rows about one foot apart and half an inch deep. When well up, thin or transplant. Fertilize with nitrate of soda or liquid. manure. Be sure to bring some plants in for the house; they do beautifully in a warm window. Indoor plants from seeds will be green and thriving in two weeks' time. A few sprays laid on a platter containing meat, or upon a salad, never fail to make the dish more 
appetizing. Parsley is also used as seasoning for soups, croquettes, and hash.

Radish. Radishes are the commonest of garden vegetables and a real delight to the beginner. There are three varieties, - spring, summer, and winter radishes, - all requiring very much the same food and care. Early radishes, in particular, love cool weather. They must have a good bed of fine, rich earth, and thus the soil must be well worked in preparation. Sow the seed in rows, one-half inch deep, not too thick. Unless the seeds have been sifted through a strainer, and the smallest cast aside, the per cent of germination is uncertain. Plant a new lot as often as every ten days at least. If wanted early, they can easily be grown in boxes, for the French breakfast radishes need only about four inches of good soil. As soon as the seedlings are big enough to handle, thin them out to one inch apart. Keep the earth always well cultivated, and as soon as the second leaves appear, work in a little nitrate of soda near the roots, but beware of letting it touch them! Use every device you can think of to make them grow quickly. Then they will be crisp; otherwise they will be tough and corky.

Winter radishes are sown in July or August. They are to be pulled up before the severe frosts come, and stored in sand. They can be freshened up by being put in cold water for an hour before they are required for the table. It is a common thing to have radish plants alternate with lettuce in a garden.

Radishes are wonderfully free from pests. The only real nuisance is the root maggot. When that does infest the soil, there is almost no getting rid of it, so it must be starved out.

Radishes will be relished at any meal; breakfast is no exception. Then, too, they always make a table look so pretty. They may be thinly peeled or not, as one chooses, or they are sometimes cut part way down toward the root end, to 
form a rosette. The fibrous taproot is always cut off, and a bit of the stem is left to serve as a handle. Most persons prefer radishes ice-cold. Often a little chopped ice is placed in the dish. When cut into thin slices they make tempting sandwiches.

Spinach. Spinach is in season early in the spring, and again early in the summer. For summer use put the seed in as soon as the ground can be worked, giving it some poultry manure or some nitrate of soda, as is advised for all leafy crops; liquid manure gives good results. A quick growth here as usual produces crisp, delicate leaves. Plant the seed one inch deep and not too thick; a three-foot bed will give astonishing returns. Here is one person's experience in spinach growing: "It germinated in eleven days; in five weeks the row was thinned, the stockiest plants being left. These thinnings from three feet of seed sown gave me nearly onehalf peck of fine greens." For early spring use the seed is sown in the preceding August or September. When the ground begins to freeze, cover it with several inches of hay. The plants will then start growing at the earliest touch of spring.

Prepare spinach for the table in the following way: Wash it in several changes of cold water to remove all sand and grit, and heat slowly in a closely covered saucepan till the juices start. Then boil hard one hour. Drain it well, chop fine, and then toss it about with a tablespoonful of butter in the frying pan. Serve smoking hot with drawn butter. Then you may truthfully say, as did some of the old-time cookbooks in winding up their recipes, "This is delicious."

Tomatoes. The tomato is a brilliant example of what intelligent cultivation will accomplish for a plant. This one is a native of warm countries. Its ancestors came originally from South America. There it was a queer little fruit, growing 
not much larger than a cherry. For a long time, indeed, it was regarded merely as a curiosity, and was called love apple. As its ancestry suggests, it needs a warm spot in which to ripen. In fact, north of the city of New York it cannot usually be planted in the open and have time to bear before frost; so plants are started in the house or in a hot frame early in March, transplanted when they begin to crowd, and set out not earlier than the middle of May. In order to develop stocky plants, three transplantings are usually not too many. If a cold snap should come upon them suddenly, they must not be expected to shift for themselves, but should be protected with newspapers or some such covering; still, on the whole, it is best not to be rash in setting them out too early. In estimating how much seed to plant, it is convenient to remember that an ounce of seed will produce more than two thousand plants; and twenty plants will usually produce more fruit than one family can possibly use, including enough to can.

Tending tomato plants requires judgment. In setting them out select the spot carefully and choose a warm place protected by a windbreak. Prepare the soil with thoroughly rotted barn manure; dig holes at least one and one-half feet apart, and unless the soil is moist, fill with water; then slide each seedling carefully into its hole. When the earth has been properly firmed and mulched, scatter, but not too near, a spoonful of nitrate of soda; then water the plants once again. Protect them from sun and wind; give them air and not too much manure; be sure not to let the plants spindle, - we can guess why. As the fruit matures, tie the main stem to a stout stake, or to a trellis three or four feet high, which has been driven into the ground near the plant. Pinch off all unnecessary foliage and keep the main stem down to three feet. Some say pinch back lateral shoots until the 
plants are over two feet high; others advise retaining three branches, - one main stem and two side branches. Keep the plants growing steadily by regular watering and transplanting. Pick off all fruits as soon as they ripen, whether needed or not. Of course the easiest way is to let the plants sprawl upon the ground, but it has been proved that such plants produce less weight in fruit, and that a great deal more is lost through rot.

Tomato rot and the giant green caterpillar are this plant's most formidable enemies. The easiest way to dispose of the caterpillars is to knock them into a jar of kerosene; and to get rid of rot, burn all the tomatoes affected with it, so that it cannot spread.

If the fruit does not ripen by the middle of September, the plants may be taken up bodily and hung head downwards in a cool shed, where the fruit will finish maturing; or the unripe fruit may be picked and put in drawers or on shelves to ripen. Some recommend hastening the ripening process, foreign fashion, by tying a paper bag over each fruit as soon as it is fully formed. But the tomato is one of the few vegetables whose flavor is not improved by becoming thoroughly ripe on the plant.

Tomatoes really have slight food value, and yet they are a welcome, even a luxurious, addition to our tables. Some think they taste best raw. In any case they should be peeled; this is done by plunging them into boiling water and then quickly removing them; after this the skin will slip off easily. They should be well chilled before slicing and serving. For cooking there are all sorts of recipes. They may also be preserved, canned, and pickled; they can be kept far into the winter according to the method called the Canadian, ${ }^{1}$ which reads as follows: Select fine, perfect fruit, Edith Loring Fullerton. 
washed clean, with unbroken skins. Pack the tomatoes in a stone jar and pour over them alternately a pint of vinegar and a pint of cold water until the jar is full. When required for use, take them from the jar, washing them in cold water before slicing. This method provides fresh tomatoes all winter.

Herbs. One little corner of the garden may well be devoted to the raising of some herbs. If we did not plant a few, how guilty we should feel when we met the Thanksgiving turkey. Thank you, no stuffing for us! Mint, parsley, sage, and thyme are all highly prized by the cook; these may be sown out in the open garden. Why not grow among the rest a little peppermint, some lavender for its delicate odor, and just a few catnip plants, - not to make tea of, as our great-grandmothers would have done, but as a special treat for pussy, who will go wild over it ?

Herbs are usually raised in good light earth, and they demand regular cultivation. Dry them in a warm room. If the garret is a thing of the past, then pulverize and store in an air-tight jar. 


\section{CHAPTER IX}

\section{GARDEN FOES AND GARDEN FRIENDS}

On every stem, on every leaf, and on both sides of it, and at the root of everything that grew, was a professional specialist in the shape of a gnat, caterpillar, aphis, or other expert. - Oliver WeNDELL IHolmes

A gardener tries to give to the plants for which he has become sponsor ideal conditions, as nearly as possible. He conspires with them against other eager organisms which, by shading them from the sunshine and eating up their food, would like to crowd them out. What would be bounteous living for a single plant, expanding in symmetry and beauty, would, when divided among a lot of little plants, scarcely afford to each more than a starvation diet. So a gardener must, first of all, provide for his plant children plenty of elbow room, and then he must put within their reach such infant foods as will best bring forward the individual quality, or what might be called the specialty, of each. His aim is not to produce examples of all-round perfection, but plants which do great things in some one line, as in flavor, beauty, or food value. A crispy leaf, for example, is the specialty of lettuce, and a tart, juicy stem that of rhubarb.

A good many plants not offered in the catalogues may really have as great intrinsic value as those on the seedsman's preferred list, although we call them weeds. Nobody can say with any truth, "Once a weed, always a weed." The humblest members of the vegetable kingdom may some fine day be found sitting in high places. In our grandmother's time, for instance, so delicious a fruit as the tomato was looked upon 
with suspicion, if, indeed, it was not shunned as poison. The Russian thistle, which lately gave our Western ranch friends such alarm, is to-day praised as a superior food for live stock and is actually sown on their farms. Travelers speak with much gusto of the dishes they have relished in other lands, but on inquiry we find that some of the best of these are concocted out of the very weeds, or cousins of the weeds, that straggle along our roadsides. Through such instances we learn not to be snobs; we come to understand better every day what Emerson meant by saying that a weed is a plant whose worth has not yet been discovered. A distinguished chemist goes still farther in his prophecies. He says, "I believe that there is not a by-product or a residuum or a weed in our fields which will not be of value to human beings." A family in the suburbs is following up this hint in their home gardens. They have set apart a certain space where each year they cultivate experimentally a few unfamiliar food plants. Some of these are plain weeds which promise well, but to which, as far as is known, gardeners have never deigned to give attention. Others are foreign food plants, highly valued abroad but almost unknown as yet to American housewives.

The members of this enterprising family interest themselves not only in developing these obscure plant virtues but, after the plants are raised, in preparing them appetizingly for the table. When they have succeeded with some new plant which they find palatable and nutritious, in high glee they call the neighbors in. This is one of the by-pleasures of the garden. A well-known gardener recommends for consideration such plants as chicory, okra, chervil, pe-tsai, prickly spinach, and Sakurajima radish. Another suggests purslane, mustard, charlock, and peppergrass. Pigweed, we are assured, makes delicious greens, Shall we try it some day? 
Although we are willing to concede that weeds have reason for being, no gardener will, except by special "permit," grant them the freedom of his garden. Still, getting rid of them is a great problem. In special instances it has been found that these nurslings can be destroyed in their cradles by sterilizing the soil. In greenhouses this is now often done by a hot-water process. Acting on this principle, some schoolboys not long ago tried baking in their mothers' ovens the topsoil for their vegetable gardens, - and with fair success. But sterilizing presents altogether too many difficulties to warrant considering it seriously for general practice. Really the only way to disturb these weed nurseries is by hoe or hand weeder. For a nature-study class, collecting the weeds of a region, mounting them so as to show their life histories from seedling to fruit, is well worth while. This is in direct line with the work of the experiment station.

Somehow weeding is always referred to as the lowest form of drudgery, and so it would seem like putting on airs for us to claim that it can be anything else. Has it not been said to require a cast-iron back with a hinge in it? And yet in this occupation, as in every sort of toil, much depends upon the purpose for which it is being done. We cannot doubt Stevenson's sincerity, for instance, when he wrote to his friends from that garden in Samoa which he loved so dearly: "I went crazy over outdoor work. Nothing is so interesting as weeding, clearing, and path-making. . . . If you could see this place. It will be a home for angels." 1 And as a bit of encouragement for ourselves, just fancy what weeding in the tropics must be!

Enters now a second trouble. Even the mildest-tempered farmer is apt to lose patience when he sets out to rid his farm land of the fungi that calmly nourish themselves upon the 1 R. L. Stevenson, Vailima Letters. 
tissues of other plants. These fungi include the scabs, the smuts, and the blights. They do not sound pretty; nor are they. Each fungus falls upon its own pet victims. Potatoes are commonly attacked by a scab which appears sometimes on the tuber itself and sometimes on the soil surrounding it. This is easily recognized. If the scab is already established upon the potato, a good sun bath given to a pile of potatoes all ready for planting will work a cure. Potato plants suffer from a blight also. This blight looks like a white mildew, and it may be detected on the stem and leaves. Celery too suffers from a blight or rust, and so do beans. On beans the rust attacks both leaves and pods in wet weather, so one must never brush against them when they are covered by dew. Various sprays are recommended for driving away the villains; Bordeaux mixture is one. Corn smut is a serious malady which takes the form of a swelling that may appear on any part of the plant system. Underneath the silvery white coating there will be noticed a black mass filled with fibers. Get rid of these at all costs, lest they spread. Burning is the only sure way.

Every plant, moreover, has its insect followers. But again no gardener, amiable though he may be, will voluntarily go shares with animals, who, like himself, enjoy a delicious salad. To be sure, since many of us, men and beasts, have such similar gastronomic tastes, it is not becoming in humankind to be too supercilious: And yet it is fair play to get ahead of these insects if you can. Sometimes the game is ours; not infrequently it is theirs. It is a significant comment that in all probability not a single pest wrestled with by man, since he came to abide on this earth of ours, has ever been stamped out. At the present time six hundred million dollars' worth, at the very least, of foodstuffs in the United States is being destroyed yearly by insects. It really amounts to paying a 
tribute equal to one tenth of all that is raised. This tax will strike even the optimist as extortionate. If for no other reason than to diminish the number of pests, a plea is being made that the gardener will cultivate beautifully a small plot which can be held in check rather than a large farm that runs wild. This course is recommended independently of the fact that by intensive treatment a small field will yield at the very lowest estimate a double crop. Any countryside has cause for rejoicing if it has united in some coöperative scheme that will wage common warfare on these enemies. For they are great rovers; therefore one family's garden depends upon another. In the work of extermination a whole neighborhood must pull together. If one lone garden goes to the bad, all the rest suffer.

It would be hopeless to try to enumerate even the common insects that bring sorrow to the farmer. The best that can be attempted here is to lay down a few principles and to suggest a general working plan. To learn more, one must consult some of the many manuals on the subject.

The first step, however, towards learning to protect plants from pests is to determine what sort of feeder each insect is. Among the injurious insects there are what we may call two grand methods of feeding. One method is chewing by means of an elaborate set of jaws; the other is piercing the tissues and sucking out the juices. A potato beetle and a squash bug are representatives of these two types. After examining their mouth parts with a magnifying glass, no comment will be required upon "their tricks and their manners"; suffice it to say that each does full justice to the delicate tools, whether for sucking or for lace-making, with which he is equipped. To destroy chewers it will be necessary to sprinkle some sort of poison on the plant, either in liquid or in powder form. If the plant in question is like the potato in that its 
leaves are not used for food, the treatment is simple enough, but great caution must be used to prevent scattering poison on the leaves of plants that are to be eaten as greens or salad, lest sad results follow.

The treatment for sucking insects - the bugs — is, however, different. These escape death by poison because they drink deep, and so some way must be found to choke or to smother them. This is accomplished by spraying with an emulsion of kerosene, combined sometimes with whale-oil soap. Hand spraying with a quart-size atomizer is not hard. Yet, after all, in a small garden nothing is so effective as doing the work by hand; this means picking off the pests or shaking them into a jar of kerosene, being careful not to let one escape.

It helps wonderfully to be able to recognize at a glance the common insects in each of their various stages, to watch for them both above and below ground, and if possible to outwit their strategy. This again is in line with the work of the experiment stations. A pair of butterflies, for instance, whirl about on a sunshiny morning, dancing like fairies with their pale, spotted wings. Where did they come from? Less than a month before, each dainty creature was an egg, belonging, in fact, to a cluster of hundreds of tiny eggs that had been skillfully gummed upon the under side of a juicy cabbage leaf. Not many days clapsed before a transformation took place and the eggs hatched into caterpillars, soft and green. Coming into a rich inheritance of new cabbage, each little caterpillar promptly began chewing its way into the crisp inner leaves. Its span of life is, in fact, largely passed in this land of plenty, first in the caterpillar and then in the chrysalis stage, where it rests awhile before coming out a butterfly. Twice a year, at least, new broods of cabbage caterpillars are hatched from eggs. The canny farmer will of course not 
miss catching this elusive creature in some one of its life stages. If the neatly hidden eggs fail to attract his eye, the caterpillar itself must on no account be allowed to escape. Destroying the eggs, or, better still, catching the butterfly before the eggs are laid, is by all means the most economical course. In this way he puts a certain end to hundreds at one stroke in preference to pursuing the myriads of caterpillars after they begin to wend their devastating way. Of the cabbage butterfly, agriculturists say that it is probably the only butterfly that should be destroyed wherever seen.

Moths and butterflies usually winter in the pupa form, either as cocoon or chrysalis. They respond so quickly to a rise in temperature that they often surprise us by appearing as one of the signs of spring while the snow still lies in patches upon the ground. The potato beetle tides over the cold weather by creeping into the ground as a full-grown adult and remaining there torpid but alive and ready to take up its occupation as a master chewer at any favorable moment. Most beetles and bugs, however, pass the winter in a resting stage as pupæ, and do not emerge in adult form until a fortnight or so after the spring sets in.

The ground is so full of a number of things! It is, in fact, a regular hatchery. And yet most girls and boys, and men and women too, go on their way little suspecting what wealth of life swarms beneath their very feet. But the scientific gardener is rudely awakened to the situation. One season's experience is quite enough for him. Before the summer closes he has at least resolved to keep the soil perpetually stirred and to leave it rough in the autumn. By this act he will join hands with the elements. He thus not only takes advantage of the first light fall of snow, which has long been known as the "poor man's fertilizer," but he relies upon frost, rain, and sunshine to quietly but effectually wipe out the line 
of descent in many a prolific family. Picture if you will how this treatment would affect, for instance, the corn worm. Offspring of a dull yellow moth which feeds on tomatoes, peas, and beans, it goes through the changes from caterpillar to moth in an interval of three or four weeks, during which it is buried out of sight. Again, the cucumber beetle conceals its eggs in the soil around the cucumber, squash, or melon, and the young larvæ feed luxuriously upon the roots.

The tomato worm, child of the five-spotted sphinx moth, goes through its transformations underground after the same fashion. Rose beetles, the scourge of every garden, which are so apt to appear, out of a clear sky, as it were, on some fine June morning, will have made all their preparations for their début within their subterranean homes. For the eggs are usually laid in the ground in early summer and hatched into grubs which feed on the roots of grass and remain below ground through the winter. Not until spring do they pass through a brief pupa stage, coming out as perfect adults in a short month.

The cutworm, progeny of the owlet moth, is most successful in carrying on its dire operations during the watches of the night. Though the eggs are laid above ground, both caterpillar and moth are nocturnal, and that is why they are able so successfully to escape destruction. The caterpillar, on emerging from the egg, hastens to a spot of safety underground, coming out of its hiding place, however, at night to nibble the tender stalks. By scraping away the loose earth one may get a look at him. A true account is given by a man who, puzzled by the mysterious devastation of his orchards and vines, heard one night as he walked across the field what sounded like the grinding of countless jaws. On striking a match the mystery was solved. The trees were simply alive with hungry cutworms. 
Fortunately, such serious disasters do not happen every season, or a gardener would probably become a pessimist. Looked at from the point of view of science, there is for even these troubles some small compensation. They offer a wide field for biological study. Few animal types are more interesting than insects, or better worth children's attention. The cycle of life through which these tiny creatures pass may be watched with keen interest. Children like to construct insect cages in which a whole life drama from egg to adult can be enacted. Naturally in these cages the normal condition will be imitated as nearly as possible; and afterwards many variations in food, temperature, and light can be tried. They may study the cutworm too, contrasting it with our benefactor the earthworm, as well as aphids, or plant lice, the San José scale, and the tomato worm. To this list will probably be added other forms, such as the garden slug and the mosquito.

Our enemies having been vanquished, in theory at least, and the question settled as to who's who in the garden, let us now turn to a study which is just as profitable and infinitely more cheering. This consists in getting acquainted with animals which distinctly benefit the garden. There are some "beasties" which a garden really could not live without. Of course, a gardener will learn not only to recognize and protect these, but deliberately to cultivate them.

There are insects whose very life work, so it would seem to a casual observer, consists in saving a farmer from pests. One of these, to which he might well take off his hat, is the ladybird, or lady beetle. This little creature's food is chiefly plant lice. Any one who will watch it for a short quarter of an hour, industriously disposing of hundreds of aphids, is sure to become its ardent admirer. The lady beetle is never daunted. She lays her clusters of yellow eggs, bold as a lion, 
in the midst of a swarm of these aphids. From the moment the young hatch they may be said to "do the duty that lies nearest to them," which apparently is to clear of parasites the leaves upon which a kind Providence has placed them. These larvæ are grotesque creatures. Black with reddish spots, or occasionally blue, they bristle all over with so many warts and spines that no wonder they themselves are not relished by other animals. They consume indiscriminately plant lice, scale animals, and the young, eggs and larvæ, of all sorts of insects. In both the larva and adult stage this little beetle carries on its scavenger work. It belongs in the list of animals which will repay indoor study.

It has been thought that the nests of these lady beetles, whose habit it is to hibernate snugly in balls, as these are called, under piles of brush, might possibly be collected and distributed in infested gardens. Why not try it? There seems also to be no reason why lady beetles may not be kept alive through the winter on house plants, but up to this time nobody appears to have done this successfully.

There are a number of other beetles whose use should be recognized. Conspicuous among them is the tiger beetle, a fierce consumer of caterpillars. Then there is the ichneumon fly, a sort of parasitic wasp, which acts as an insect killer for nearly every sort of plant. Its habit is to lay a bunch of eggs on or in the body of the larva of some other insect, with the result, of course, that this larva is consumed by the newly hatched intruder. The cleverness with which this egg laying is accomplished is certainly marvelous.

Of ichneumon flies there are many species. They vary greatly in size, several of them being very beautiful. One species drills into the firm tissue of trees, in order to lay her eggs in or upon the body of some wood-boring larva, which, concealed well beneath the bark of some handsome maple, is 
riddling it with fatal holes. Another species performs what is little less than a sleight-of-hand trick, that of stinging a caterpillar in the very act of spinning its cocoon, for the sake of depositing a bunch of eggs inside. This makes assurance doubly sure that the eggs shall be wrapped up safely in the swaddling clothes of its victim. If school children are engaged in raising caterpillars, the tent caterpillar or the sphinx in particular, they can in due time see the spectacle of parasites emerging by dozens from the caterpillar's body.

There are sure to be pools, large or small, not far away from the garden; and pools mean dragon flies. These exquisite creatures are happily to be counted among the gardener's friends. Their motions are fascinating to watch, and their life stories read like fairy tales. What is more to the point, their food includes many annoying insects that swarm in the air on a summer's day, such as gnats, flies, and mosquitoes. The dragon fly is clever at catching and eating these on the wing, and the wingless young dragon fly or nymph does his share by prowling about in the water and consuming many a "wriggler."

The worth of toads to the gardener is now so universally recognized that it only remains for him to study the best ways of keeping and breeding them. ${ }^{1}$ A great deal may be learned indoors by contriving for a pair of toads a snug little home where they can live a somewhat normal life and can exhibit their very characteristic tastes in food. The fact that they are greedy for garden slugs and all sorts of lively, hopping insects, preferring these to all the other foods that are set before them, speaks eloquently in their favor. One pet toad is so obliging as to eat no less than one hundred rose bugs in the course of a night. For a city lot, which perhaps has long

1 Usefulness of the American Toad, United States Department of Agriculture, Bulletin No. Iq6. 
been toadless, it will really pay to import a few toads. Therefore go on a still hunt some day and bring them home in a bag. These adopted children are not apt to thrive so well, however, as those born and bred in the garden, but this, in the cases we know, may have been largely a matter of luck. An arrangement for breeding them in a little pool, where they may be raised from the egg, has afforded one family many an entertaining hour. In any case, since the eggs are always laid in water, at least some contrivance to encourage breeding should be provided. Nobody can help enjoying Mrs. Thaxter's amusing account of establishing a colony of toads in her garden.

One other animal, so useful that it might be properly named the "First Aid to the Garden," remains to be properly mentioned. It is a creature that associates itself with the earliest principles of agriculture. This is the earthworm. How to make children appreciate at first hand the almost priceless value of earthworms to the world deserves more than passing consideration. "It may be doubted," says Darwin, "whether there are any other animals which have played so important a part in the history of the world as have these lowly organized creatures." 1 Their activities are indicated by many signs. The little mounds of castings show us where their burrows lie. Brush away the stray leaves and grass that they have pulled down into their burrows, and you will find a channel extending many inches below ground.

In the course of making a burrow, not only has the earth been crumbled up and enriched, but the holes afford easy passage for air, for water, and for rootlets. The morning after a warm rain is the time to find belated earthworms that have been tempted, through their enjoyment of refreshing draughts of water, too far away from their burrows. But to find them

${ }^{1}$ Charles R. Darwin, The Formation of Vegetable Mould. 
at work is a different story, since during the day they remain quite listless. Darkness is the season for their industry. Hunting earthworms with a lantern may sound tame sport, but it is, on the contrary, curiously exciting. If one approaches the worms stealthily, they are seen lying stretched along the moist surface halfway out of their holes. The hind end still clings to the burrow, while the mouth is sucking and tugging toward the hole scraps of leaves and grass. The ease with which its wonderful elastic body is able, by expanding and contracting, to accomplish such feats offers one of the most striking lessons in animal mechanism. The reaction of the worm when stimulated by the lantern's rays and by human footsteps may also be noticed. All these feats may be watched in the laboratory if the worms are kept in a darkened jar and the curtain raised from time to time. A performance fascinating to children is one where worms are eating tiny bits of filter paper. There are a great many other experiments which any one who carries on a vivarium will propose of his own accord.

Children are not by nature prejudiced against animals like toads and earthworms, except that any unusual forms or movements are at first disconcerting; but the example set by their elders, it must be confessed, is not always reassuring. The perfect harmony which earthworms display, through generations of adaptation to their surroundings, and the survival of the ones best equipped for the struggle of life, is an inexhaustible source of interest and admiration, although everything depends, as has been said, upon the point of view. The easy adjustment of children to a new point of view may be illustrated by a little incident.

A small girl of ten had shown a strong antipathy to some earthworms which she found lying in the garden path. She was so disturbed that her work was stopped, her pleasure 
spoiled. The garden teacher, with a quick eye for the situation, explained on the spot to the children the value of animals to the garden, sparing no pains to do the earthworm full justice. Not many days after, the child was seen traveling to and fro, intent, it appeared, upon some important business. "What are you doing, Susan?" "I am collecting earthworms for my garden." A zealous convert to the new thought, she had been industriously gathering from all parts of the lot dozens of writhing worms, which she was proceeding to "plant" in ther own individual garden, a space six feet by eight.

Perhaps, on the whole, a gardener's most faithful allies are the birds, and if so, it is his duty to protect and to cultivate them. Every bird, except the English sparrow, is what may be called a "paying guest," and some birds are really priceless. Farmers have shown themselves incredibly shortsighted in not balancing fairly the virtues of birds against their mischief, especially when their helpful acts would so clearly seem to outweigh their troublesome ones. And yet mistakes are inevitable when acting, as they have commonly done, on the basis of snap judgments instead of the basis of actual experiment. Admitting that birds, like children, have their troublesome moments, who is mean enough to refuse a modest payment in cherries, if that is the currency preferred, to a bird like the robin, which often consumes in a day hundreds of pests? Mr. George T. Powell says that he makes it a point to set out a few shrubs which birds especially like, on purpose to discharge his debt to them.

If we hope to coax them to our fields and gardens, we can only do so by studying their tastes. A pan of mud for swallows and robins, hair for the chipping sparrows, as well as bits of thread, yarn, and twine, will all be woven into some dainty nest; and all sorts of birds will find a drinking basin and a bath most acceptable. 
Some of our familiar birds eat almost nothing but insects. Such are swallows, flycatchers, warblers, swifts, and humming birds. Others, although not exclusively insect eaters, may nevertheless be depended upon to consume insects by the multitude. Among these are the bluebird, robin, catbird, thrush, chickadee, cedar bird, grackle, and woodpecker. A pledge to which every gardener should be proud to subscribe is the following: "I promise to do all I can for all native birds, by treating them with kindness and providing them with food, water, and homes." 1

' Hodge, Nature Study and Life. 


\title{
CHAPTER X
}

\author{
SIDE SHOWS
}

\begin{abstract}
And in the windows, either side the door,
Were ranged as many little boxes more

Of like old-fashioned larkspurs, pinks and moss

And fern and phlox; while up and down across

Them rioted the morning-glory-vines

On taut-set cotton-strings. - JAMES WhitcomB RILEY
\end{abstract}

The most attractive features of a school garden are likely to be its accessories, or what may be called, for short, the side shows. These accessories give peculiar pleasure because each one will have been undertaken by youngsters who have hit upon their hearts' desire, and who have decided to seek it in company with a few chosen spirits. No such group, however, is really cut off from the rest. The responsibility of "making good" is no light one, for it is required of them in their allotted space to do something worth while; their experiment must be a credit to the whole garden.

Questioned as to why he is putting so much energy into a purely voluntary task, one eager worker gave, in substance, the reply of a keen Irish woman who, when urged to tell her idea of heaven, answered racily, "Hearen? Oh, heaven is doing the-job you like." The self-elected jobs of the children are of all sorts and kinds. The experiment plots already spoken of, for instance, may be counted among the popular and instructive accessories. Other schemes may not connect so directly with the soil itself.

A project which in every garden deserves to be encouraged is some well-planned contrivance for protecting the birds. A 
community should look to its gardener to take the lead in establishing intelligent and protective measures.

Time was, and not so long ago, when many species of birds gladly accepted the hospitality of a bird house. This they would still continue to do if it were not for the opposition of the tyrant sparrow. For, as we know to our sorrow, just in proportion as the English sparrow has fought his way into a locality, the native birds have been driven farther and farther back. At present comparatively few will breed in boxes unless by some means this fellow has been banished. So scare him away, if possible, till the other birds begin to build. Fortunately, there still remain as many as twelve species of birds which may be counted upon to come regularly to spots where their peace can be assured.

Among these are to be found four kinds of swallows: the chimney swift, the house wren, the bluebird, and the phobe. Neither the robin nor the nighthawk can as a rule be tempted to nest in boxes, but both will occasionally breed on the tops of buildings. As for those handsome members of the woodpecker family, - the flickers, - strange to say not very many attempts have been made to entice them into neighborhoods; and yet they are such famous insect hunters that it would seem well worth trying. This ought not to be difficult either, if their tastes can be judged by the amusing pranks they sometimes play. Tales are told of how, as cold weather approaches, they cut little porthole-like doorways for themselves, and serenely enter some unoccupied summer cottage, where they settle snugly for the winter, to enjoy the comforts of home. Often they are not discovered till spring. It is therefore proposed to offer them at least the alternative of an all-the-year-round cottage of their own.

The bluebird is sure to become a family friend, provided we have an orchard or some mowing land near by. This 
lovable bird has, however, very decided tastes in architecture; his house must be "just so," and, by the bye, it should be completed before his arrival, early in March. In shape it should be long and deep, the interior suggesting the hollow of a tree. Knowing this, any young architect can suit him to perfection by cutting a section of some fallen log or limb and nailing to this two small boards, top and bottom, one for a piazza and the other for a roof.

Again, in many localities martins will readily make themselves at home; they become great favorites on account of their grace and their entertaining habits. Most of their food they get on the wing. They are accustomed to live together in larger colonies than birds of less powerful flight, and so they need a spacious residence. Being so conspicuous, this needs special protection; a galvanized iron pipe has been found to make an excellent standard on which to set it, the house thus being completely insulated from four-footed visitors.

On the whole, the best style of bird box is that which furnishes its little tenants with the most complete shelter from the sun and storm. This can be secured by cutting the doorway to the bird's own measure, and also by placing it high up under the projecting roof. The door-size for a chickadee, for instance, is only about one inch, or at most an inch and a quarter, in diameter, whereas a hole seven eighths of an inch in diameter exactly fits a wren. To crows, jays, gray squirrels, cats, and such raiders this house in itself would then signify a polite but firm "No admittance."

Moreover, the projecting roof serves a further purpose in preventing pussy from indulging in her naughty pastime of reaching in and clawing out the birds and their children. Where bird boxes are nailed upon poles or trees, they may be made puss-proof by means of a sort of collar of wire netting which will stand out at right angles around the trunk or pole. 
A clever contrivance is to arrange the projecting roof of each bird box so that it can be opened and closed, and by some good device securely fastened down. This lid will allow the children to peek into the boxes occasionally and, when necessary, remove nests of mice and other robber visitors. Various devices have been made for studying the nesting habits of birds without disturbing them. One is to have the side of the box arranged as a door, with a pane of glass set behind it so that when the door is opened the birds' behavior can be seen.

Suppose we have succeeded in providing birds with satisfactory homes, what more can we do to make their sojourn happy? Probably what all our bird guests need most, whether they are transient or permanent, is an abundant supply of water. So appreciative are they of any little pool whatsoever, that they do not disdain to use, either for drinking or for bathing, a battered tin pan or cracked dish. A device, however, which seems to suit them, and which at the same time adds to the attractiveness of a garden, consists of a perfectly plain granite block, with its upper face slightly hollowed so as to catch the rain.

The story of the construction of a bird fountain in a school yard in the city of Worcester has already interested a large circle of bird lovers. It is worth repeating on account of the ingenuity shown in designing the fountain, and also because of the excellent example it gives of how a school and the community may pull together. The plan, it appears, was worked out by the teachers and the children. First, it was necessary to get the approval of the Board of Education; then, the cost having been estimated at fifty dollars, the children, the teachers, and all their friends enlisted to help raise the sum. The contributions were many, and of many sorts. Volunteers among the boys dug the trenches for the pipe and 
for the stone foundations; the expert piping was done by the city plumber; the solid gray slabs of field stone were presented by Clark University to its infant sister, the grade school. A teacher ${ }^{1}$ wrote the following:

When the mason began his work, he was allowed to put in the foundation as he thought best, but after that he placed every stroke under the

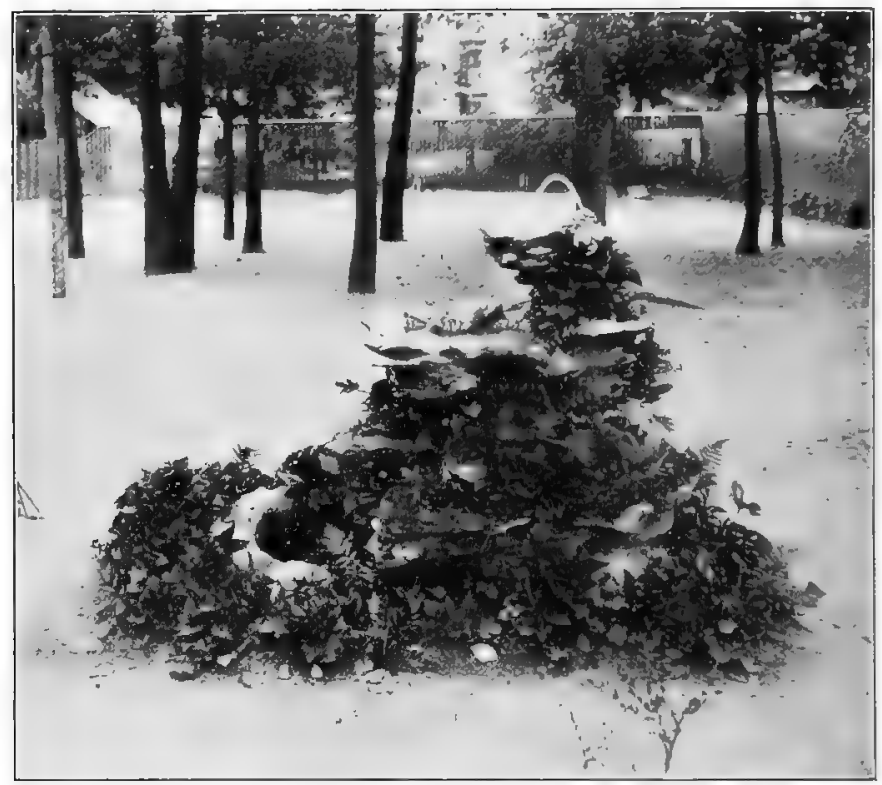

THE WORCESTER BIRD FOUNTAIN

direction of those whose minds held a completed picture of the fountain. The mason frankly told us that he thought he should not care to carve his name on the fountain as its builder, but he followed our suggestions exactly, and after a day's work the structure was finished.

The completion of this interesting structure was hailed with joy. Especially after the carefully planted wild flowers

1 Miss Edna Thayer. 
began to peep out from the crevices of the rough stone, it proved to be an object of real beauty. More important still, the birds recognized it as their own; and best of all, the school yard, through this service to the birds, became the center of deep neighborhood interest, the dedication of the fountain to the use of the birds being an occasion of high festival.

In a flower garden nothing can equal the effect of a fountain or a quiet pool. It is convenient, too, for watering plants. There need be no fear of breeding mosquitoes if a few fish are put in to eat the larvæ.

Again, a hive or two of bees becomes a very interesting feature in a yard or garden. The situation of the yard matters little, for these wonderful creatures are remarkably independent of their immediate surroundings; the hive may even be kept indoors, so long as the bees can come and go, - with their own latchkey, as it were. The experiment of keeping bees was tried about a year ago in a certain Boston school. A hive was fitted neatly into a window in the third story of the building, so that the bees flew industriously in and out through a little passageway near the sill the whole season long. It was an observation hive - one with glass sides set up by a group of schoolgirls as a part of their naturestudy course. The scheme was their own; theirs too the expense, amounting in all to several dollars, which they paid out of their own pocket money. It amused them, they said, to see how many people, who would not have turned to look at a bee on a dissecting pin, thought nothing of running up three flights to see a bee at work. An observation hive is becoming no unusual accessory to a nature-study equipment.

Probably a still more unexpected spot for a visitor to find beehives is in the very heart of London town. A colony of bees now adorns what is probably the one peaceful nook in the noisy and once notorious district of Whitechapel. It is 
here that a gray and ancient churchyard has lately been turned into a recreation ground for children. ${ }^{1}$ God's acre, as the Germans call a cemetery, would thus seem to have become God's acre in very truth. This charming spot includes flower beds, old trees, and a little nature-study museum. Classes of children visit this garden regularly, and with the help of a teacher their eyes are opened to the wonder of the natural objects that surround them.

In various home schools beekeeping is taken up more seriously than has been found practical in day schools. The children are disciplined by the responsibility, and they learn something of this useful industry. At an English school, for example, situated in the beautiful region of Petersfield, the writer saw five prosperous hives. The entire care of these was intrusted to the boys and girls ; for a period of one term three or four pupils took charge. Their report of bee culture for the summer term, published in their school paper, ${ }^{2}$ begins thus : "This year we fed the bees very early, giving them candy, and so they were in splendid condition by the time the Dutch clover, which is the chief honey supply in this district, came out."

Then follows an entertaining account of the methods employed in managing the brood, introducing a new queen, and in swarming, the text being supplemented by a telling photograph called "Hiving the Swarm." The report ends with a close estimate of the total yield of honey, which they expected, that season, to bring up to one hundred pounds.

It is easy to see how an interest in beekeeping, if awakened in connection with school gardening, may some day introduce a lad or lass into an occupation that will bring him a handsome profit. A well-known Cincinnati man makes a living from bees which he keeps on the roof of his house. Another in New York City, one of the large dealers in beekeeping

1 Miss Susan B. Sipe, Washington, D.C.

2 Bedales Record. 
supplies, has installed several colonies on the roof of his warehouse. This great building looms up in the very center of traffic, where one expects to find business humming, to be sure, but not bees. How they can possibly make a decent living is certainly a puzzle.

With these and similar instances in mind we may easily believe Mr. Benson ${ }^{1}$ when he says, "It may be safely said that any place where farming, gardening, or fruit raising can be successfully followed is adapted to the profitable keeping of bees." It would be hard to believe that any one, old or young, could watch the daily lives of these mysterious animals without being set a-thinking; and those children who come to understand the social life going on within a hive, especially if they have tested the value of organization in any of their own occupations, can hardly fail to catch what is well called the "spirit of the hive."

To some persons the keeping of poultry recommends itself as an accessory of school gardening, although the line would be carefully drawn so that the two interests should not clash, for "Chickens in the garden!" would hardly be a welcome cry. Experiments in poultry keeping have perhaps been nowhere more successfully made than at Hyannis, Massachusetts. Mr. Baldwin says:

Certain very important characteristics which were not suspected from the regular school work were clearly manifest in the poultry house. In fact, enough has already come to me along this line to prove that here is a new and reliable means of applying practical tests and of helping students to see and correct inherent weaknesses. ${ }^{2}$

Quite a different sort of side show, which may be undertaken by a young gardener sometime during his career, will be the

1 Professor O. H. Benson, United States Department of Agriculture.

2 W. A. Baldwin, Poultry-Raising as a School Occupation. 
construction of a simple apparatus for measuring rainfall. The purpose is obviously to measure the depth of the sheet of water that would lie on level ground after a rain, supposing that none of the water were lost by evaporation or by soaking into the soil. This is done at experiment stations by exposing a cylindrical vessel, or rain gauge, to the storm, and measuring the depth of rain or snow that it receives. A good gauge should have a circular rim and a diameter of at least five or six inches. The edge should be sharp, with a vertical face on the inside. This gauge should be placed in a level and open space, some distance, if possible, from trees and buildings (a distance at least twice their height is the rule); then it should be fastened in place, to avoid being blown over by the wind. The rim should stand a foot above the ground, and should be carefully leveled. A movable funnel is generally placed within the gauge, so as to protect the water that lies beneath it from loss by evaporation.

At a station the measurement of the amount of rain collected is usually taken by pouring the water from the gauge into a measuring tube of a certain smaller diameter, so that its area shall be one tenth of that of the gauge. The water then rises in the tube to ten times the true depth of the rainfall. This magnified depth is then measured by a graduated stick, the record being made to a hundredth of an inch. Record should be taken, if possible, at the close of every storm and always once a day, although some observers measure the rainfall only at a certain hour each day, without regard to the time when the rainfall ceased. The amount measured should always be entered in the record book before the measuring tube is emptied. Just here the hint of an expert gardener may well be followed. "Buy a barometer," he says. "By obeying a few simple rules you will be able to forecast the weather." 
That woodworking is an important accessory to gardening has already been shown in the course of these pages, but the extent to which simple carpentry can be used in and about a garden seems almost unlimited. Boys and girls can learn to construct anything, from a bird house to a greenhouse, if they care to try.

In certain private schools the laws of construction and the handling of tools are being taught not so much by graded school exercises as by actual building. The director of one such school ${ }^{1}$ writes: "We will build and place our own fences, coops, beehives, outhouses, boats, and sheds. The interest of the entire school in the progress of the work on the new boat, or the greenhouse that may be building, will stimulate the pupils engaged to do their best. Later when their task is done and the product in actual use, it will be a daily reminder of the dignity and worth of labor."

Turning aside for a moment from matters of purely economic interest, we may consider some of those that approach the æsthetic. A delightful feature now being revived from the gardens of olden times is the sundial. Young people have been known to take great pleasure in one. It often has a subtle charm for even young children. One writer recalls with what awe as a child he approached the first sundial of his experience. It seemed so mysterious, he says, this sentinel of light, - that it made a lasting impression, in which the garden figured as a little fairy world:2

Sundials, it appears, were much in vogue in the days of good Queen Anne. But as the years sped on, the custom died out, except when friends had them designed for each other in order to mark in unique fashion such festivals as birthdays. George Washington, it will be remembered, took

I The Interlaken School.

2 Loring Underwood, The Garden and its Accessories. 
great pride in his sundials. He is said to have had three, one of which, his favorite, was placed in front of the house at Mount Vernon.

Fascinating as a dial undoubtedly is as an ornament for any grounds, its special value for a children's garden would lie in

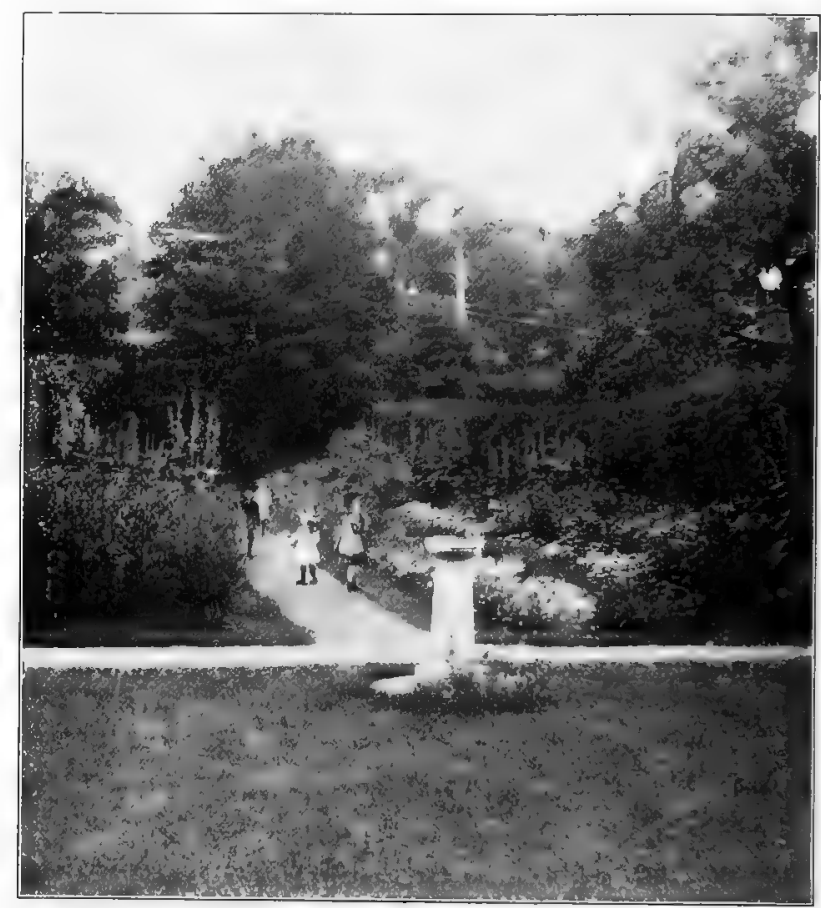

THE SUNDIAL IN THE GARDEN

the pleasure of designing and constructing it. There are, as we know, three parts to a dial : a base, which must be firm and steady; a simple shaft; and, topping this, the dial itself, consisting of a face and the accompanying style. The style projects at an angle from the face, and thus marks the time 
by the shadow it casts. Every part can be made at home, although a dial face can nowadays be bought, if one chooses. The steps taken in making one dial at a slight cost are thus clearly given :

"The pedestal was made of an old millstone; upon this was a concrete pedestal. Having planned the proportions carefully, the core of the pedestal was cut out of wood, wound with chicken wire and plastered with Portland cement and sand. The square and round sections for the base and cap were cast separately and the whole was joined with cement and water." The cost of materials was about three dollars, exclusive of the dial face, which may be obtained for two dollars.

The dial, however, will only tell the correct time on certain days in the year; so that as a timepiece it of course leaves much to be desired. Indeed, the best of dials are right only four times a year, - April I 5, June I 5, September I, and December 24, - when "apparent time" and "mean time" happen to coincide. But its persistent disagreement with the clock will bring in many an inquiry and create, perhaps, a desire to know some of the facts of astronomical geography. It will be noticed, for instance, that the upper surface of the style must form an angle with the horizon corresponding to the degree of latitude for which the dial is designed; for example, in New York the angle will be $40^{\circ}$. The hour marks must then be computed for different latitudes, and the style must point to the true north, that is, to the north star.

One of the charms of a sundial, of course, is that it will bear a motto. Deciding upon a motto for a school garden which all the children will agree upon is no light matter. The mottoes which have been adopted by eminent persons make interesting reading. "Come light, visit me," was cut upon Harriet Martineau's dial. A motto that has pleased children runs as follows: "My face marks the sunny hours. What 
can you say of yours?" Another favorite is, "Let others tell of storms and showers; I 'll only count your sunny hours." Here is a longer one too good to be omitted:

On the sundial in the garden,

The great sun keeps the time;

A faint, small, moving shadow,

And we know the worlds are in rhyme.

But if once that shadow" should falter

By the space of a child's eyelash,

The seas would devour the mountains, And the stars together crash. ${ }^{1}$

Finally, nobody who understands children will fail to appreciate how much they love to beautify their surroundings. In a garden, for instance, although they may have announced it as their firm intention to plant nothing but vegetables, before many days they will be overheard planning for at least a border of flowers. An excellent way to learn how to make flower gardens is by first practicing with borders. This will lead toward the planting of vines for backgrounds, screens, and cover-ups, and all sorts of ambitious schemes will follow.

Certainly a garden takes a long stride when, having begun its existence as a place to dig and delve in, it consciously sounds a note of beauty and becomes a spot truly to live in. Grown-up eyes may find much to criticize, but whenever children put their hearts into a garden, expressing fearlessly their ideas of beauty in terms of their own, the place cannot fail to grow in interest and charm. To the children themselves, of course, their garden naturally becomes the most enchanting spot in the world, for the same youthful imagination that can transform an old tippet into "the prettiest doll in the world " finds not the least difficulty in turning a scraggy bit of land into a perfect paradise.

\footnotetext{
${ }^{1}$ Richard Watson Gilder.
} 
In this connection certain schemes suggest themselves which are sure to please children, and which have proved well adapted to school gardens. A little arbor, for instance, or a pergola thatched with leaves that cast dappled shadows on the even paths, or the simplest of summerhouses, - these are sometimes constructed in gardens not a block away from the clanging cars. A summerhouse, to answer every purpose, does not need to be a large and spacious structure like that which the Clinton Park children enjoy in New York. No carpenter ought to be required except for consultation. Here is offered, in fact, the very occasion where the children's own woodworking bench comes most handy. The one rule to be observed now and always is that every bit of carpentry, however rude, should be built not in fragile and earwiggy fashion but substantially enough to withstand the stress of the weather and the seasons. Two "chunks" and a board, for instance, will make a seat; and, wonderful to relate, a stump is transformed into a table. Such woodworking fancies, if carried out, can turn a sober, homely spot into a real pleasure ground.

Properly directed, this desire for outdoor beauty may favorably react upon the home. In the hurry and rush of American life many phases of domestic enjoyment remain incomplete. The interior of the house itself is often truly a world-famous example of modern invention and convenience, but the setting of the house leaves usually much to be desired. According to the "American custom," each city and suburban house has, of course, its front grassplot shaven and shorn into immaculate greenness, and conforming as exactly as possible to that of its neighbors. The little lawn may be broken by a border of flowers or a bush or two, but it is seldom improved by a haphazard addition of this sort. Although this style of yard is conventional and uninteresting, still, improvement is 
rather the concern of the trained landscape architect than of the ambitious young fledgling, so that one would be rash indeed in these few pages to suggest changes.

Permit us, however, to take a look at the back yard. This can seldom be called too civilized or too conventional. On the contrary, it remains in savagery. Its gods are apparently the washtub and the flapping clothesline. The services of

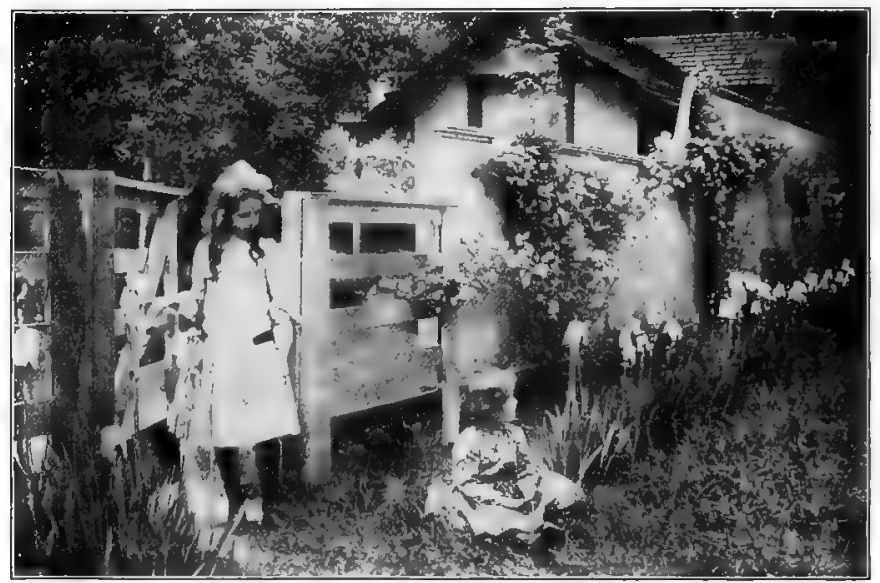

A LITTLE BACK IARD

a missionary are certainly required. So little are the possibilities of a back yard appreciated that a proposition to make it beautiful has many a time been greeted with derision. That the back yard is probably tiny is a foregone conclusion, but so was the old Salem garden whose summerhouse is thus described. "What a refreshing sense of comfort these vinecovered structures gave to the little back-yard gardens. Here the housewife would come to shell peas and pare apples, or to read awhile in the cool shade after a hot fight with the unwelcome weeds of the garden. And the children of the 
household, how they loved this miniature bower where they could play at 'keeping house ' to their hearts' content." 1

Crossing the water, we get, if possible, more glowing pictures still. Everybody who has had the luck to peep at English gardens, - not the stately ones adjoining great manor houses, but those snug gardens belonging to cottage life, - must have a longing to adapt some of these ideas to the American yard. The idea would be more farreaching than merely the production of a tangled mass of greenery, which at its best harbors a swarm of insects, although such a thicket in the landscape is doubtless a step in advance of mere 'barren wastes. But our English cousins have developed by long training a rare perception for

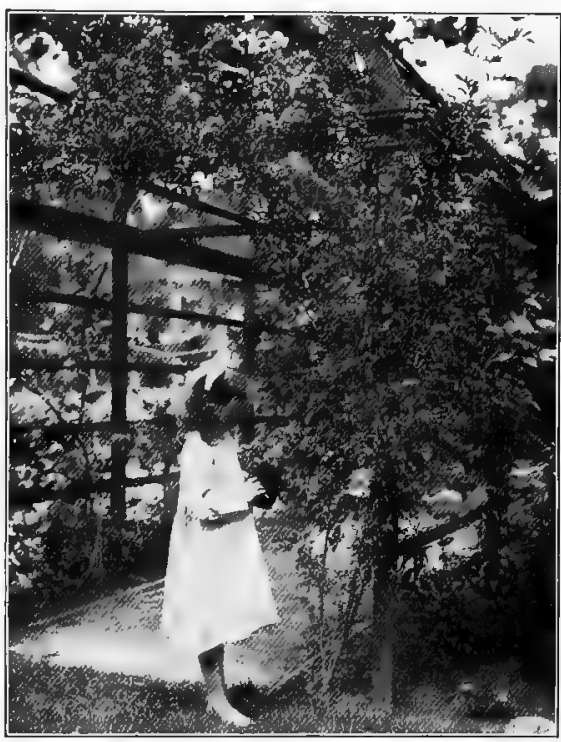

HER OWN CRIMSON RAMBLER exactly the elements that produce cosiness and comfort. Many secrets in the art of home making they can teach a willing learner. Not the least of these is the effective use of the back yard. In their skillful hands the back yard becomes the outdoor living room, a real withdrawing room. It constitutes the very pivot of restful life, giving charm to reading, sewing, and the lighter meals of the day.

1 Loring Underwood, The Garden and its Accessories. 
One English garden will always remain to the writer a delightful memory. It lay in a quite impossible district, an arsenal borough of greater London. The straight-angled streets were walled with workmen's cottages two stories high and of a depressing sameness. A knock at the street door meant an invitation to step across the threshold and go through the tiny passage over a second threshold out into the garden. This garden covered scarcely more square feet than the ground plan of the scrap of a house, but by some magic an atmosphere quiet and lovely pervaded the spot. The din of the street hardly intruded beyond the high wall, which, softly padded with English ivy, inclosed it like a green nest. Next came the border beds, fairly ablaze with tall spikes of color. A little path led this way and that, and coaxed you into a half-hidden arbor. Across, in an opposite corner, there peeped enticingly a sunny bit of kitchen garden, spicy with fresh relishes, for the table. Involuntarily one drew a long breath of satisfaction. For a moment this seemed the one unhurried spot in all the bustling world. You could fancy how the family might eagerly look forward to a break in the afternoon's work, signaling the appearance of the much-loved teapot and what might easily prove the most precious half-hour of the day.

Two things are worth looking forward to in American life: the leisure to plan for outdoor comfort and beauty and the leisure to enjoy these when once they are secured. Children will help their elders to accomplish this. When youngsters and oldsters combine, and with one accord set themselves to learning how to create a beautiful outdoor home, whole families are easily drawn into a life of fuller enjoyment and attachment.

Thus one side show suggests another, and one desire kindles another, until by and by the whole neighborhood is astir with enterprises and becomes a brighter, happier place to live in. 


\section{CHAPTER XI}

\section{NEW LIFE IN OLD SUBJECTS}

\footnotetext{
"The old gods pass, the cry goes round,

Lo! how their temples strew the ground, Nor mark we where on new-fledged wings

Faith like the phœnix soars and sings."
}

"Education is developing by doing real things." These words have the familiar ring of an old song. They would not bear repetition here if action were as easy as speech. In spite of the best of theories it is safe to assume that some of us are still preparing our young. people for a life that lies dimly ahead of them, or which we guess lies ahead of them, instead of marching with them step by step in tune with the life that pulses around them.

Just as far as a child is left to experience the ups and downs of life alone, isolated in spirit from his elders, just so far he will necessarily be self-taught - and this means half taught - in the lessons set him in the great school of life. Is it strange that many a youth becomes submerged by the rush of new experiences? The wonder is that his courage and his integrity are so often saved.

In the schools of the past, as a matter of course, academic questions pure and simple absorbed both teachers and students. There are, in fact, schools still existing to-day where classes are kept busy solving mythical problems about mythical butter and eggs at mythical prices, and where they are still practicing the art of composition by writing acceptances to imaginary invitations from imaginary cousins at the antipodes; in a word, unregardful of the real things going on 
all about them, these young people are constantly kept "supposing." There are, fortunately, on the other hand, schools that interweave their routine with children's real pursuits, so that it is hard to tell where school leaves off and a child's free life begins.

Roughly speaking, school exercises may be said to fall into two classes: one made up of the tasks which spring from real issues, the other consisting of the tasks set for the express purpose of acquiring tools, - for tools are useful in the execution of these real activities. Spelling, for instance, and handwriting should be classed among tools (both of which accomplishments the man of affairs passes over to his typewriter), besides a large share of the mechanical side of arithmetic. Tools are of course necessary; on occasion a tool may rise to the highest importance. The desire to possess a specific tool and the price one is willing to pay for it are conditioned upon the seriousness of the piece of work whose success is at stake; in other words, the workman prizes his tool and learns to wield it effectively according to the value which he sets upon the work.

Is it assuming too much to believe that there are matters pertaining to education which vibrate with permanent interest independent of clocks and bells? Surely not. Skill on the part of the educator lies in not letting slip any opportunity to utilize a single one of these permanent interests. He is becoming every day more keenly alive to such opportunities. That this is everywhere increasingly true is indicated by so obvious a sign as the subjects chosen in these days by students for their themes. Time was when "How I spent my" Vacation" stood nearly alone in a string of arid titles like "The Pleasures of Hope" or that classic subject "Duty performed is a Rainbow in the Soul"; but the list of school themes nowadays reads something as follows: "How our 
History Class came to act 'Julius Caesar,' " 'The Way to install a Salt-water Aquarium," "How Two Girls found a Market for their Sweet Peas." Such titles indicate no fanciful situations; they are firmly linked to the children's real occupations. Let us see if this is not so.

\section{HOW I EARNED SOME MONEY LAST SUMMER 1}

After the ground had been plowed and harrowed and I had raked over a piece of ground about seventy feet by six feet, so there were no big lumps in it, I took the line and made a little furrow close to the line. Then I scattered the seed into it, making five such rows for about thirty feet, and only two rows after that for potatoes.

Then there was a good deal of watching for the first sign of the plants. When they could be seen easily, I went up and down the rows loosening the soil, so that they could grow more quickly. I planted about a foot of lettuce then later on I transplanted it getting about fifty cents for it.

I planted about thirty feet of cauliflower. When they became large enough to transplant I dug them up leaving one good one every foot and those that I dug up I sold to my father for one half a cent each. I sold him about seven hundred so I earned three dollars and a half. When they were large enough, I tied the outer leaves and sold them. When the heads were nicely bunched and solid I got about two dollars for them.

I had also planted some beets but they were ill-fated. The man was cultivating some of father's trees and cultivated them under. I planted some more but they were taken for beet greens while I was away. The weeds grew pretty fast but with half an hour a day they were soon conquered, then onions and carrots brought me some money, perhaps four dollars.

Then there was another way of earning money and that was by picking berries. I got two cents a quart and a backache for picking strawberries and earned about four dollars in all for them. For raspberries I got two cents a pint. I earned about three dollars for them. In all I earned for my summer's work seventeen dollars.

Among all the subjects acceptable for school exercises, gardening takes high rank in introducing practical issues. It

1 School composition passed in by Beatrice Field. 
has proved itself a real force in education on account of these very "connecting qualities." In other words, it makes a capital bridge, the academic end of which is to be found in the seclusion of the school, while the other end reaches into the very midst of the bustling world. Like a little

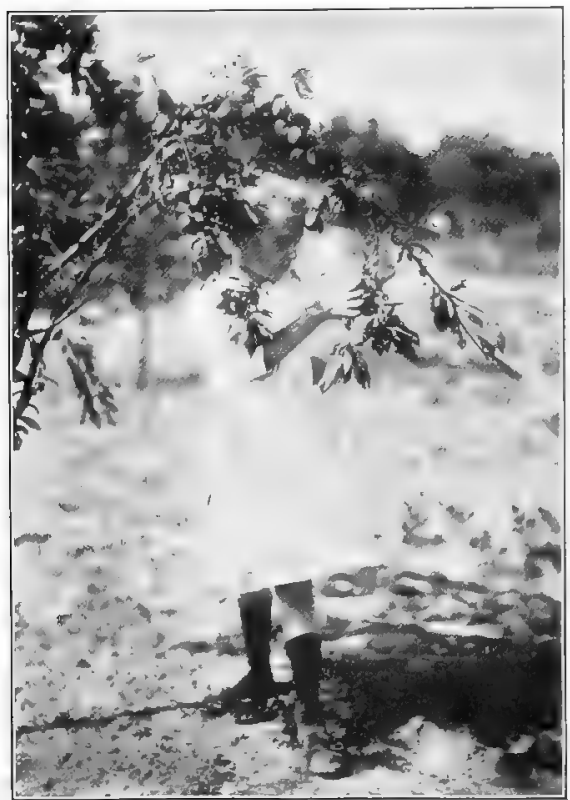

ARE THESE READY FOR MARKET? whirlpool the school draws into its sacred precincts the social activity and the hard sense of the market and of the street; and on the other hand men of affairs are showing every day that not all the good teaching in the world is being done in the schoolroom or by a teacher. In gardening, the verdict as to whether things are fit to eat, or to sell, makes a welcome substitute for the oldtime marking system. However stiff a test this may be, it is at the same time so stimulating that one begins to wish that all the products of a school were of such a nature that they might be carried to market.

Another advantage in the pursuit of gardening is that it does not limit itself to a neighborhood, to a township, or even to a continent; the interest is spread far and wide. The tidal wave of modern gardening is felt round the world. 
It appeals, moreover, to both young and old, - - to the schoolgirl, to the business man as an avocation, to the woman as a means of livelihood in her suburban home.

Grown people will naturally gravitate into some specialty that peculiarly attracts them. Whatever the undertaking, it is reasonable to expect them to excel in matters requiring experience and judgment; but we should not forget that children have their preferences and their line of superiority as well. They are the ones who see things at a flash. Often they go far ahead of their elders in keen-eyed discovery, - and a discovery surely has its intrinsic worth, whether made by a professor or a kindergarten child. It is the selfsame fable of the Mountain and the Squirrel that is every day being enacted in one form or another.

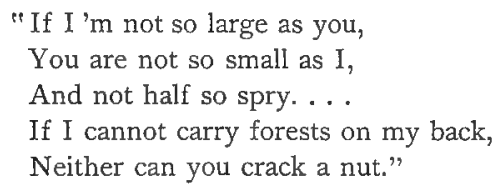

And surely in the gardening world every one finds his niche.

But however desirable it might seem to add gardening to a scheme of liberal education, the daily program for every school day stubbornly resists; it is brimming full and running over. Enthusiasts must therefore bring sober proof that the time which gardening takes from conventional study is not merely time well invested, but that it can enrich by a substantial dividend these very subjects. One thing is constantly being demonstrated: it is that trying to carry on successfully even the simplest garden kindles the desire for precise knowledge. It is only too true that without the habit of exactness the gardener finds before long that he is playing a losing game. He sees that he may as well stop competing if he cannot acquire skill enough to hold his own. This does 
not refer to manual skill alone, or even to technical garden lore, but to skill in some other matters not so self-evident. To illustrate: he must master the art of figures, of measurements, and of calculation. In trying quickly to get the $\mathrm{A} \mathrm{B} \mathrm{C}$ of a business situation the bearing of mathematics upon his present task all at once dawns upon him. What does it signify if up to this time arithmetic has been the most cordially hated subject in the curriculum? The exercises that teach him exactness must be mastered. Upon this ground, if on no other, mathematics justifies itself even in the mind of the beginner. Certain parts of the arithmetic get learned from the very pressure of pure interest.

Not all the subjects included in the school arithmetic would probably be needed in the gardening of a single grade during the season; square root, for instance, would hardly be required. Look through the textbook and check off one by one the various subjects that have been dealt with as the result of the demand of a garden; it is a surprise to find how many are included. A committee of teachers, who lately met to compare their experiences, unanimously agreed upon two points: that a curiously large proportion of the arithmetic usually assigned to a child's school course is positively required in garden work, and, on the other hand, that the garden furnishes an extraordinary number of practical problems illustrating mathematical principles and rules. One teacher gives her experience in these words: "The correlation of arithmetic with the garden work is positively necessary. The large garden has to be divided into individual gardens whose areas are alike. As these may be square, oblong, or triangular, it takes quite a bit of arithmetic to equalize them. Then the problem work used in the class can be based on the productions, the outlay, and the gain. To have the problems real makes the reasoning processes easier." 
A list compiled by a small company of teachers included the following subjects: long, square, and cubic measures (with constant practice in mensuration), liquid and dry measures, and weights; the measurement of time by clock and sundial; the use of the thermometer and barometer; percentage, averages; tabulating by curves; calculation of the amount of material needed for given areas, such as fertilizers, seeds, and bulbs, to be distributed at different intervals in a specified area; drawing to a scale; the understanding of geometric forms and facts. In addition there may be included the intricacies of business arithmetic, such as the handling of money; keeping a cash account; bookkeeping; bills, receipts, and checks; interest and commission; the reading of market quotations as a basis for figuring and for fixing prices. A person could probably go through life very well if only so much arithmetic as this were thoroughly learned and "lived."

More valuable even than facility and practice in arithmetic may be counted the development of the business sense and a timely initiation into honorable business methods. The prudent buyer and the honest seller are the stuff out of which good citizens are made. Nowhere may integrity be shown more conspicuously than in packing goods skillfully and labeling them truthfully; in just this work there will be shown the advantage of earning a reputation for square dealing. We may remember in this connection that the Father of our Country, as a young man, had the reputation of growing the best tobacco in Virginia, and that barrels of flour marked $\mathrm{G}$. W. were suffered to enter foreign ports without inspection.

Business, furthermore, must often be done through correspondence. There are various types of the conventional business letter. Every scholar, before he leaves school, is supposedly equipped with a formula with which to meet the emergencies in letter writing that are likely to arise. Some 
of the models put before scholars conform, indeed, faultlessly to the standard of the polite letter writer; and yet the notes received by business houses, so we understand, are often as void of personality as an empty clamshell. Perhaps there is often "too much model," and in all probability the young applicant has never had any practice in framing an actual letter. There is certainly no reason why a note written under real conditions should lack personality. In order to learn to write a good letter, two things are imperative: a genuine purpose and plenty of practice. Gardening will never fail to supply both of these conditions.

"Early in the spring," writes a city teacher, "as soon as seed catalogues were advertised, each child wrote his own real letter asking for a catalogue, addressed it and mailed it. It was in many cases the first letter they had ever sent. Of course their letters were inspected as to writing, spelling, and punctuation. Then for our regular writing lesson the copy written on the board was often either some garden maxim, as 'Make hay while the sun shines,' 'Take care of your garden and your garden will take care of you' (there is a variety of these in 'Poor Richard's Almanac'), or such sentences as 'The beans are all up.' 'John's garden has no weeds,' and so on."

The letters demanded in garden correspondence are of all sorts, but they will often be in the line of asking advice and acknowledging attention and kindnesses. Correspondence will sometimes be carried on with persons occupying official positions. An answer from a public man or his secretary will be eagerly watched for; its arrival rewards any youngster for all the pains expended upon the original letter. These replies are often preserved among the garden records; sometimes the most distinguished ones are framed. To earn an answer, young people learn that a note must possess certain characteristics : it must be clearly and correctly phrased; it may not 
in any way suggest bluff; and yet it must have carrying power, - that is, every word must ring with sincerity, - and the writer must bear the marks of being a young person whom it will pay to bother about. The way to seem worth while is to be worth while; that means constantly doing things that are worth while. Establishing such connections with older persons on common ground has no equal for arousing ambition.

Having once entered into actual relationships with persons at a distance and united by a common interest, makebelieve letter writing seems tame indeed. The teacher usually does not half realize how much of a farce such exercises seem to his students. Not very long ago, in a certain preparatory school where the value of practice in writing letters to real persons had been duly recognized, it was required during the spring recess that each boy should send a letter to the teacher of English composition. This

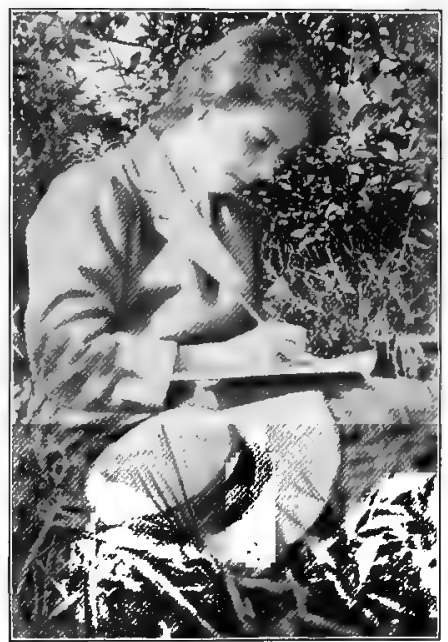

WRITING TO COUSIN EMILY ABOUT MY HERBS task was described by one of the boys to his amused family in these words: "No mistakes in spelling, no mistakes in grammar, no mistakes in punctuation, no blots, no slang, no answer!" Hardly an exercise, it will be agreed, to make a boy love letter writing.

Another method is to let the young people of a school exchange letters with those of a distant school. Letters upon historical topics, for instance, fly to and fro between the 
history classes in a Massachusetts high school ${ }^{1}$ and a school near London. May not gardening supply quite as interesting matter for correspondence as history? It may be claimed that writing reports and keeping diaries of garden proceedings afford enough daily practice and real material without letter writing. Both reports and diaries certainly call for clear and ready expression; but the drawback to such exercises usually is that they become in matter lifeless and in form careless, unless they spring from a genuine reason for writing, and for writing well.

This is but natural. Let us analyze the situation for a moment from the grown-up point of view. Nothing inspires any human being more than reading to those who want to hear, writing to those who want to read, and talking to those who want to listen. So the audience voluntarily chosen by any one, young or old, would bar out the class of persons who listen, seemingly, for the sake of pouncing upon a mistake; but it would include everybody who listens with true earnestness. Some of us can duplicate the experiences of a distinguished professional man who for years has been in the habit of laying his most intimate plans before an elderly friend of singularly lofty ideals and of a rarely sympathetic temperament. $\mathrm{He}$ attributes his success to her. Said he: "She makes me say better things than I ever dreamed. And then to be consistent I simply must follow them up in action."

The vitality which gardening can put into the subject of geography cannot for a moment be doubted. Next to exploring strange lands one's self comes the privilege of seeing the world at second hand by associating distant spots with friends. Friends are often scattered abroad in many climes. Are not plants friends? If so, bulbs carry us across to Holland or to Puget Sound, formal gardens to Italy, coöperative gardens to Denmark.

1 Charlestown High School. 


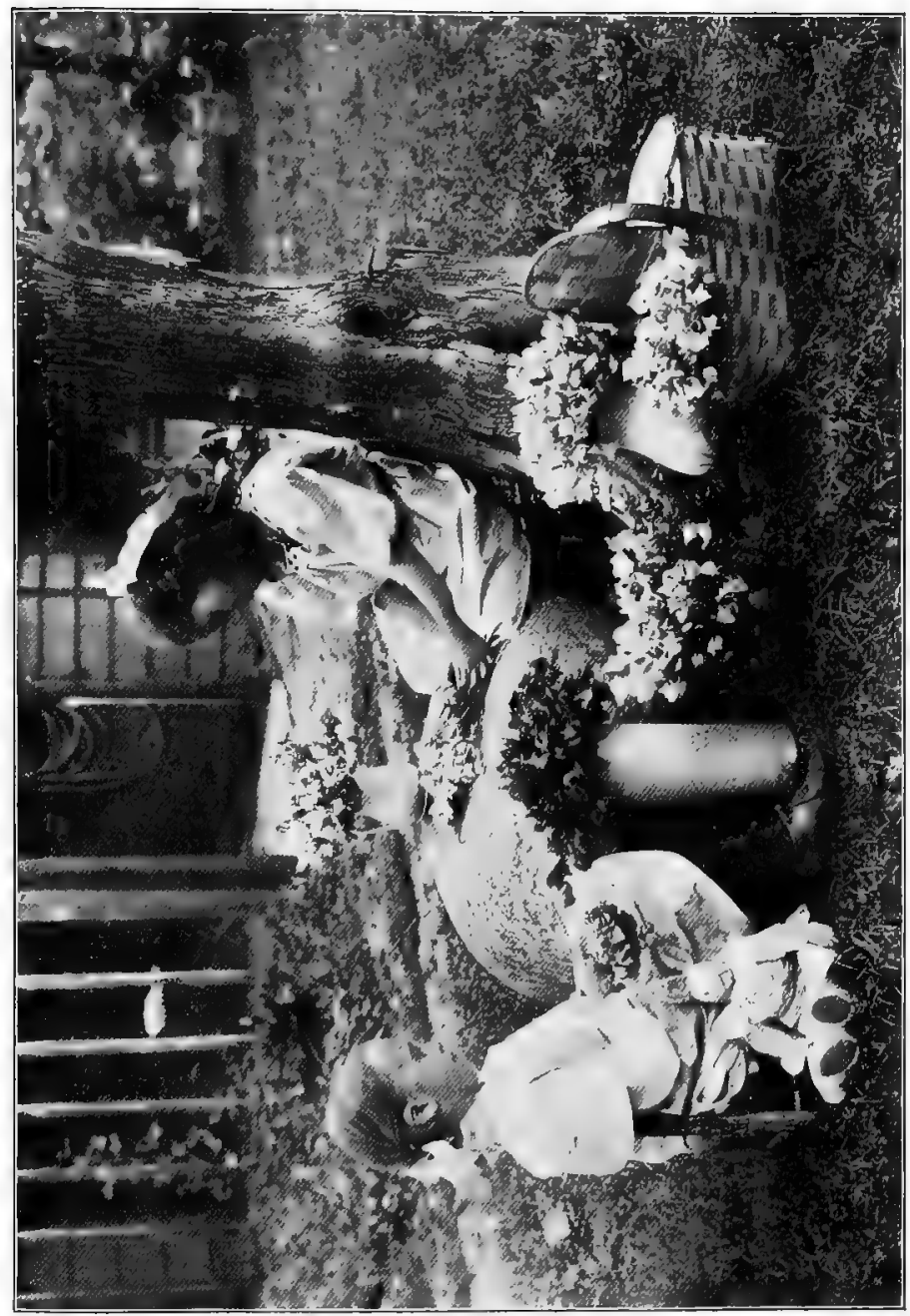

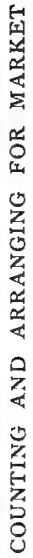


It is quite a common practice to raise cereals, hemp, and flax expressly for the geography classes. One teacher ${ }^{\mathbf{1}}$ offers a list of five plants which in her school have proved particularly valuable. These are hemp, tobacco, flax, peanuts, and rice. She says: "In connection with the hemp growing of Russia and the Philippine Islands, the planting of hemp seed became a highly desirable thing. The interesting young plants were eagerly watched and tended. The vigorous plant, with its strong, unusual, and beautiful foliage, attracted general admiration. Its rapid growth and great size were enthusiastically noted. In the fall the plant was studied carefully, the stems being pulled apart and a kind of rope, of the long, tough fibers, made in the classroom by the boys. This led easily to lessons on rope making, kinds of rope, and the various uses of rope."

We should certainly expect the growers of plants to be the ones who could best arrange flowers and fruits, whether for home enjoyment or for sale. What eyes could possibly discern more quickly and display more lovingly the best features of their products? Fruits often decorate a room or a dinner table more effectively than flowers. At exhibitions the art of arranging fruit and flowers receives distinct recognition. It calls out special talent and demands special training. On these occasions prizes are sometimes offered for excellence in this respect alone.

"In our school building," writes a seventh-grade teacher, "the children supply the drawing teacher with flowers for her lessons during the season. We asked her beforehand what she would like to have us plant, since some plants were more desirable than others for her work. These were used in sketching, designing, and in the color work."

It is a short step from garden to kitchen. In gardening the schoolgirl finds opportunities which belong almost wholly

${ }^{1}$ Miss Elizabeth Mailman, Rice School. 
to herself, for in addition to the general crops which interest all there are certain products which find their way straight to the school kitchen. It is she who collects the grains and other foodstuffs for the kitchen laboratory. She stores savories and garnishes; she triumphs with the preserving kettle. A row of jars reveal their opalescent contents and bearwitness to her housewifely skill. In one school, fruit from the garden was preserved and sold at the recent fair for the Teachers Mutual Benefit Fund. ${ }^{1}$ What is more natural than that the successful grower of vegetables should wish to see these safely simmering on the stove? An enthusiast on the cooking of vegetables may shed a glamour over the most commonplace cooking.

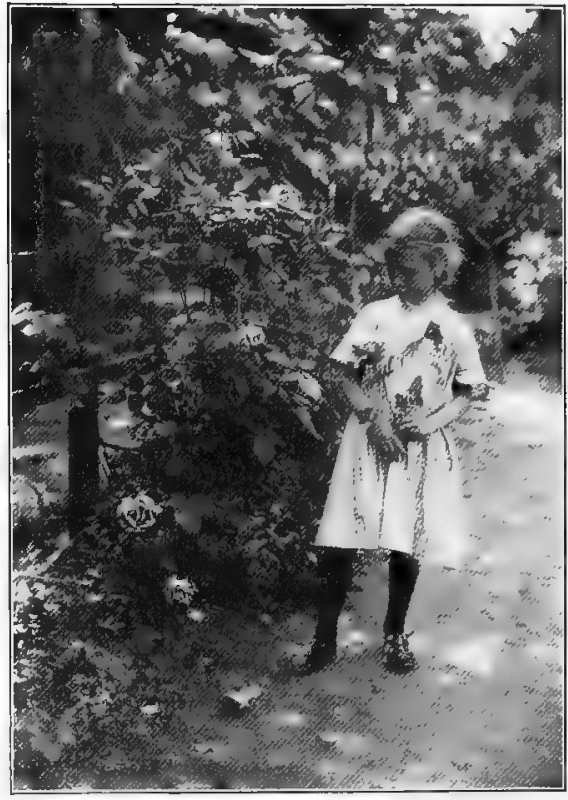

WILL THESE DO FOR THE DRAWING LESSON? The cooking of greens, for example, is raised to the level of an art. "Some cooks add a little water when placing them over the fire, but others heat them gently to draw the juices out of the leaves. In either case the leaves should be cooked only till tender, and should be a good green,

1 Miss Anne Withington, Report of the Boston School Garden Committee, 1905. 
not of a washed-out, brownish tinge. A small amount of salt may or may not be added before cooking. Authorities differ on this point, but I have used both methods and prefer to add salt after the vegetable is cooked. Cabbage should be boiled in salted water of $212^{\circ}$ heat." 1

It is not strange that nature study and the beginning of scientific pursuits should get their strongest impulse from gardening. It is said that all the nature study a child needs can be learned by working in a garden. Some believe that this is claiming too much; but are not those who object usually the ones who have taken gardening in a literal and narrow sense? There are certainly moments when it seems to a teacher as though the garden lay at the very heart of the world of science, so many truly scientific impulses have been known to begin or end there. As a source of material for study, it certainly does not run dry; the animals and plants that jostle one another in a tiny space are likely to confuse a pupil by their very abundance and variety. Again, the problems suggested in a plot, however small, are universal problems. Where, indeed, can be seen more strikingly the effect of environment, or the survival of the fittest?

Bypaths, such as studies of spiders, of fungi, or of our native shrubs and trees, are all possibilities which, sighted through some garden experience, may be opened up to the young gardeners. A hand-to-hand conflict with pests makes children see the advantage of a knowledge of animals and of a collection of insects for study. As a result, a taste for natural history begins to bud. A small collection, including at first only "local celebrities," quickly outgrows its original cases, and some day the delivery of a mysterious package, plastered all over with Brazilian stamps, records the fact that rare beetles have arrived for a boy's really valuable collection.

1 Edith Loring Fullerton, The Vegetable Garden. 
But even suppose for a moment that nature were less lavish, is it, then, the amount of material that determines the effectiveness of study? On the contrary, have not the great teachers of biology always laid stress upon the ideas of science and the methods of science? And have they not, on the whole, opposed as a mischievous and unscientific practice the accumulation of myriads of facts, which, in their confusion, not only fail to reveal, but which cloud the truth? As a rule these masters of science, resolutely eliminating side issues, put before their students a few carefully selected cardinal type forms. They trusted in the principle that through patient, hard-won intimacy with the mechanism of some type organism, - an earthworm, it might be, a fern, or a fish, - a student's scientific power would reveal itself; and so indeed it proved.

To further answer those who worry lest boys and girls may confine their attention to mere marigolds and beans, it may be that they have not found out by experience that when children start on a seemingly easy quest they become, before they know it, lost in a maze of side issues. One step leads to another, much like the chronicle of "The House that Jack built." To illustrate: The gyrations of a cabbage caterpillar once led a class to a dispute in regard to caterpillars and their uses; then to the value of the silkworm; then to the silk industry and its history, including the display of raw materials; then to an ingenious demonstration of methods of manufacture, which involved investigation by reading and correspondence; then to the further study of the habits and customs of the silk caterpillar; then, on the part of one of the company, to a day's journey to the city of Hartford, Connecticut, where, at that time, in the School of Horticulture, these caterpillars were flourishing on the mulberry trees planted for them. Next followed a scheme for raising a 
colony in the children's own gardens. The same class was allured to study useful birds and their preservation, as a result of the indignation caused by the rascality of the English sparrow in their own gardens.

Overwhelmed, in fact, by the richness of suggestion, the teacher finds himself at the parting of the ways. He must either set his face resolutely against all spontaneous adventure or he must explore with his children hitherto untraveled lands. In pursuit of the knowledge for which they hunger, he is driven to undertake many a bit of research on his own account. One teacher, struck with the humor of the situation, tells amusing tales of a term during which she was literally whipped on to fresh study by her energetic scholars: There were at least a dozen "specialties " running at the same time in that class. One happened to be the gypsy moth, whose habits some girls wished to study in field and laboratory in the most thoroughgoing fashion. Their enthusiasm dragged her over hill and dale. Little did they guess through what a stiff course of discipline in investigation they were putting their somewhat distracted teacher.

This intensive nature study, inevitable when children are following to a logical conclusion the curiosity which the garden itself has stirred, may be deliberately contrasted with the skimming process necessitated by many a "quite perfect" course of study for graded classes. Is it exaggerating to say that any course, no matter in what subject, which is fully elaborated and crystallized is bound to be archaic? For if by chance one little bud of interest begins, to unfold, it will be only too promptly nipped by some of the well-known frosts of the schoolroom. Desire to know is quickly blighted by such words as "We must hurry on," or by the dread of intermittent examinations where rank depends upon memorizing facts. A little thought reveals the fact that if heterogeneous 
details and superficial methods are ever out of place, they are peculiarly foreign to the first steps of science.

The naturalist, with the vast resources of the world spread out before him, may properly scorn the need of having at his tongue's end an explanation of every phenomenon of the universe. He often finds satisfaction in saying with a royal air that he does not know. This is far from being the usual attitude of the teacher; it is more like that of the rural peddler who, till he knows his countryside, cannot possibly carry in his pack half of what his customers demand, but who, if once he gets a chance to spread out his wares, can show that he is anything but a fraud or a failure; every one then begins to wonder how in one small space he can have packed away a stock so admirable and so well arranged. Could any one in his place do better? Then with true cleverness he sees to it that on the next round he is fully equipped.

It is apt to be just the opposite, however, with the naturestudy teacher. A slave to tradition, he feels in a measure bound to pose as infallible. So, regardless of what is wanted by his students, he makes it his business to lug about with him as many facts as possible, forcing them upon his pupils at every provocation. That is really why in so many instances nature study has proved either very "thin " or very unpopular. Suppose, on the other hand, he is sustained by the belief that he can keep his self-respect, even though he may not carry every trifle about with him, the true teacher is spurred to do his best in supplying real needs; and he will have the wit to replenish his pack of knowledge, on request, to everybody's satisfaction, and be in the meanwhile as merry as the peddler.

The words "scientific research" and "scientific method" may seem pompous terms to use in educating youngsters; they certainly will so appear to any one who associates the phrases with nothing less intricate than a compound microscope. But 
the scientific method simply means the path by which a person arrives at first-hand truth about the natural world. It means inquiring of Nature how her processes go on. It means, not thinking at a superior's command, but thinking to satisfy an inner purpose whose fulfillment brings its own best reward. It teaches how to estimate a guess - a working hypothesis - at its true value, and how to prick the bubble of a sham. Some of its results, as shown in everyday living, are patience, simplicity, and sincerity.

The examination of evidence from many sources leads to the conviction that by allying a garden with the time-honored subjects in schools, academic work may be greatly enriched. Instead of robbing these studies of so many golden minutes, the garden may kindle a fresh and unquenchable desire for their pursuit. Yet what adventurer will expect to step aside from the beaten path without getting into a tangle of difficulties? One very common obstacle which some allow to deter them may easily be anticipated. A piece of industrial and social work like the garden, used as a practice ground for other studies, disturbs the peace of a cut-and-dried program. Although it is a positive nightmare to the good people who rely upon rigid sequence in courses of study, such programs are fast being left behind; methods do indeed move. It is only one short generation since it was seriously required that children should spell according to the graded course of study ordained by the spelling book. And some remember very clearly the wail that attended the passing of the old speller. The teachers of those days, expressing their views colloquially, would doubtless have confessed that they were afraid, once their comfortable prop was snatched away, that they would never know "where they were at." Yet, in spite of much protest, only good has probably come from the innovation of teaching not at the pace set by the dictates of theorists in a 
publishing house but in accordance with children's daily needs ; and freedom to do this, whatever the subject, stimulates the teacher. Certain it is that every time a teacher repeats the happy experience of answering real questions, of ministering to a child's actual need, she becomes less tolerant of stuffing even willing children with information to be used in later life.

Not long ago it happened that some visitors were listening to an examination of the Little Housekeepers class. Many questions had been answered with surprising accuracy and promptness. Finally, a question was passed along from child to child accompanied by scowls and shakes of the head on the part of the little girls. The question was, "How often should windows be washed?" This important fact had of course been taught, but somehow everybody had forgotten. In this moment of suspense one child spoke out, to the surprise of the teacher and the delight of the visitors, "When they need it." This refreshing answer might be given with equal effect by many a grown person regarding matters of detail in a course of study.

Some, at least, of the instruction given to children might properly be furnished them in response to their own demand. Older persons, of course, are in a measure justified in anticipating the needs of the future for their children; and yet no generation, with all its store of wisdom, has ever sounded exactly the dominant note of the next. Many are the mistakes in education which are never told in words. Indeed, it is only when some distinguished man or woman discloses the incidents of his early training that we listen, startled by the truth. Pitifully enough, many of these failures have happened in the discharge of what is piously called the parents' or the teacher's duty. The shortsightedness of teachers is a byword when it is a question of recognizing in a pupil the taste 
for scientific work. The words of Darwin, for instance, give every true teacher a pang: "The school as a means of education to me was simply a blank." Quite a different type of man has recently summed up his life in a New York school thus: "In fact, my life at the North Moore Street School was, with the exception of the playing at recesses, when I occasionally indulged in a fight with my pet enemy, Harry Dupignac, one long misery, one long imprisonment." 1

Just so far as the school estranges itself from a child's personal experience, just so far are both his life and his school impoverished. May not the school lessons and the lessons in the school of life unite in one great onward current? There are some prophets who say that in the future these will in all essential respects flow on together.

Let real things, then, in greatest abundance go on in the garden. Guide young people; do not thwart them as, in the process of growing, they stretch out now in one direction and now in another. And in the meanwhile, not in order to make gardens but to help nurture joyous souls, let the course of study become so plastic that all sorts of activities may be worked into the beautiful substance which is life.

1 Sit. Gaudens. 


\section{CHAPTER XII}

\section{THE YOUNG FARMER'S ALMANAC}

"Tell you a story," my beautiful dear,

"Of nixies and pixies and fairies with wings!"

Well, curl up close in the corner here,

And I 'll show you more astonishing things.

Celia Thaxter

Gardening is an all-the-year-round occupation, yet some of us, who see how rushed a farmer is when spring comes on, might well think of it as his busy season and ask what a farmer does the rest of the year to kill time. The joyous call of all growing things in the springtime is really only a part of the story; spring happens to be the climax of a year of strenuous preparation, and during those months his industry is just as real, though not so striking. The spring planting, upon which so many hopes hang, is actually anticipated weeks - yes, months — before a single seed goes into the ground. Several important pieces of work must have been satisfactorily done; any one of these by itself would keep mind and muscle steadily employed. Take merely the preparation of the farm land, and consider what skill and endurance is necessary to get it into shape. Consider also the planning necessary in growing plants under glass. Preparation cannot be made a week too early nor a day too late; the right moment waits upon the weather. To tell "when" takes a good guesser. Looking ever forward, mapping out work, readjusting his plans to events as they come along, becomes second nature to the expert. There is no month in the calendar when he can afford not to "watch out." One market 
gardener said that his business was to grow vegetables, but that he himself must look out not to vegetate.

To prove that the need of constant activity is not imaginary, we have here sketched out the work of a twelvemonth. The calendar which follows is compiled from items that appear in the records of young gardeners, some of whom have worked at school and some at home. It shows how the various tasks are likely to be distributed through the different seasons.

The almanac reads as follows :

September: Keep the hoe busy. Avoid digging around shrubs and trees. Rake together the weeds. Get the ground ready for bulbs. Harvest the main crop of potatoes. Collect seeds from the onion, cabbage, beet, turnip, and radish plants that have been allowed to mature for this purpose. Put these away in paper bags plainly labeled. Keep them cool and dry. Pile more soil around the celery. Look out for slugs. Complete a collection of common insects, especially to show their life histories for mounting and study in the winter. Complete also a collection of common weeds, showing the plants in blossom and in fruit ready for identifying and mounting.

- Sow spinach and kale for next spring's crop. Plant seeds of trees; it is well to plant some nuts. Set out hardy perennials. Plant all sorts of hardy flower seeds: columbine, foxglove, Canterbury bells, sweet William, as well as annual poppy, coreopsis, and mignonette. Plant sweet peas now or a little later in preference to early spring, and if the weather is unusually warm, delay a little, for they should not begin to sprout now. There will be many more weeks of warm weather, so save the tender plants from the first frost. Bring out old mats and newspapers at a moment's notice.

OCTOBER: Rake together all remaining weeds and fallen leaves to start a new compost heap. Bring in the final crop of pumpkins, squashes, onions, and potatoes. Leave the turnips and the salsify. Freezing improves the flavor of salsify. Cover the chard to carry it through the winter. Trench the celery before the frost. After the ground freezes, cover the strawberry bed with loose straw; this gives better fruit than a mulch. Plant winter rye early to turn in for humus. Set out bulbs. Trim the shrubs. Set out new shrubs. Prepare cuttings. Pot the house plants for the winter. Exchange plants with the neighbors. Gather the 
ripened cereals; save some of the kernels in jars ready for the study of foodstuffs. Label all the seeds. Exchange with friends at home and at a distance. Balance the books for the season just closing.

November: November is the clearing-up time. Tidy the whole garden. What do you say to setting out a dwarf apple tree? This is a good time. Cover the bulbs as soon as the ground has frozen hard. It is a good rule to keep the ground covered with something, a growing crop is desirable; then it retains its richness. Spread on manure and fork it in lightly. Leave the ground rough, so that the air.may get in. Transplant evergreen ferns from the woods for the garden and for the house: rock ferns, the Christmas fern, Asplenium ebeneum, are all attractive. These and other growing plants make the most charming Thanksgiving decorations and Christmas gifts. They will grow in low Japanese dishes or deep glass saucers. Arrange them as nearly as possible as nature does; do not try to add to their beauty with ribbons and tissue paper. Partridge-berry vines are always lovely. Freesias, Chinese lilies, and other bulbs may be coaxed to blossom for the holidays.

Look over the tools, sorting out those that should go to the shop. Polish them well with vaseline or boiled linseed oil before putting them away. A gardener is known by the tools he keeps.

DECEMBER: This is the month to get your collection of insects and plants mounted and arranged. Supplement by books and reports your own personal experiences with the growth and behavior of plants. You will be surprised to find how much there is in the newspapers and the popular magazines. Plan additions and improvements to be carried out in your own garden. Decide upon your garden specialty for the new season; a garden never repeats itself. Work in the shop; make labels and trellises. Do all sorts of tinkering in odd moments. Dibbles can be made, for instance, out of broken spade handles. Paint the signboards and labels which you think will be needed for the coming season. White letters on a green background is the choice in one garden. It is effective and not too staring.

If there is any manure to spare, make a present of a wheelbarrowful to your favorite shrub or vine. It can be spaded in whenever the ground permits. Don't burn the Christmas greens; they make a good coverlid for half-hardy plants outdoors. Form a garden club, if you have not one already in your neighborhood. If it is a young people's club, admit a few jolly grown-up people as honorary members. Get as many entertaining books as you can on the subjects that interest you; talk these over at the 
club and then get the family to read them aloud in the evenings. If you are to be the reader, look up beforehand the meaning and the pronunciation of the hard words; practice a bit beforehand and you can give much pleasure. A few pictures, a specimen or two, or an experiment of your own shown along with the reading will make it as interesting as an illustrated lecture.

JANUARY: Bring from the cellar the bulbs for the house. Begin to test seeds for the spring planting. Visit the big seed houses in order to keep apace with their appliances. If your home is too far away, so that not all in a club can go, then subscribe enough money to send one or two members who will give a first-rate account to the rest. Start some plants in boxes just for the sake of experiment. Renew subscription to a good garden magazine for your own reading and for exchange. Country Life and The Garden Magazine are two of the best. Sort newspaper clippings that are worth saving, for your scrapbook. Write for the new catalogues and the new Agricultural Department bulletins. Put in your order before the rush.

FEBRUARY: Visit forcing houses and greenhouses. Visit the big market to see how the bounty of many latitudes is heaped at our very doors. Sow the first lettuce, cabbage, tomato, and peppers indoors to transplant in due time. Tin cans and cigar boxes will be in great demand.

MARCH : Plant indoors a second series of vegetables : cabbage, eggplant, and parsley; sow also lettuce, radish, and tomato seed in the hotbed. Raise some hardy flower seedlings to set out. Asters and nasturtiums will be good. Uncover the perennials and the bulbs. Work the dressing well into the ground ready for outdoor planting. Wait a bit if the ground is still wet.

APRIL: A long list of vegetables may be sown in the cold frame. Many can also be planted outdoors : potatoes, onion sets, early peas, as well as radish, lettuce, parsnips, beet, carrots, salsify, spinach, and chard. Put in some corn, if you are willing to take risks, and then you may be able to crow over your less optimistic neighbors. Gather the glassgrown lettuce and radishes. Uncover the rhubarb and feed it up well. It will surprise you by growing famously within a headless barrel set down over it. Keep a watchful eye for the eggs and larvæ of insects. Allow some to develop in the house, but guard against their escape. Tend the wild garden. Plant seeds of the trees that are fruiting. Plant acorns, horse chestnut, peach, and apple seeds. Unite in some neighborhood project for Arbor Day celebration. 
MAY : Here is an old rule: "Plant first corn when the shadbush is in full bloom, or when the leaves of the white oak are as large as a mouse's ear." Plant and transplant for all you are worth, watching always for vacant spots that will accommodate extra seedlings. Transplant from the frames: beans - plenty of them - beets, corn, and cucumbers. Melon and gourds may now be started. Thin out bravely. Get the strawberry bed in shape. Spare some attention for the flower beds. Plant such seeds as cosmos, mignonette, phlox, zinnia. Don't forget to watch the beehives closely just now; the bees may swarm at any time.

JUNE : June provides work enough of all kinds to keep things humming. Lettuce, onions, early peas, spinach, kale, and rhubarb are ready to gather. Fill the spaces with a second sowing. Continue faithfully thinning, transplanting, and cultivating. Arrange a spring exhibit of the products of the garden, and display at the same time the results of any experiments that have been tried. This may be made a real event in your neighborhood. Weed early and late.

JuLY : This is the month for planting some late vegetables; cabbage and corn are most popular. Sow lettuce in the vacant places. Prepare the ground for winter turnips. Sow more turnips and carrots if you are fond of them; also a fresh supply of beans and beets. The end of July is generally the driest time in the whole summer.

August : In August keep ahead of the weeds. Plant late spinach. Sow lettuce once more. Thin the turnips and parsley. Take out the early potatoes. Put aside the medium-sized potatoes for "seed." Dry them in piles in the sun. Plant in their place winter spinach. Prepare for the autumn exhibit of fruits and flowers. Label a few of the handsomest flowers to save for seed. Keep the rest of the flowers well picked. Write the records of the year. Show profit and loss.

The march of the seasons brings to the school gardener a problem which the market gardener does not have to confront. This is the break, the chasm it may rightly be called, made by the long summer holidays. For the welfare of school gardens these holidays come at just the wrong time. How to bridge this period is a puzzle indeed. Some teachers admit that they are quite helpless in the solution of the matter, and merely compromise as best they may by planting only those 
vegetables that will ripen before the end of June, frankly giving up the crops that need attention during July and August. The writer of a recent popular book on nature study would have us accept the notion that a school garden can, without much attention, "worry through the summer," as he calls it. "In fact," he continues, " a neglected garden may be made to furnish some excellent lessons in the study of

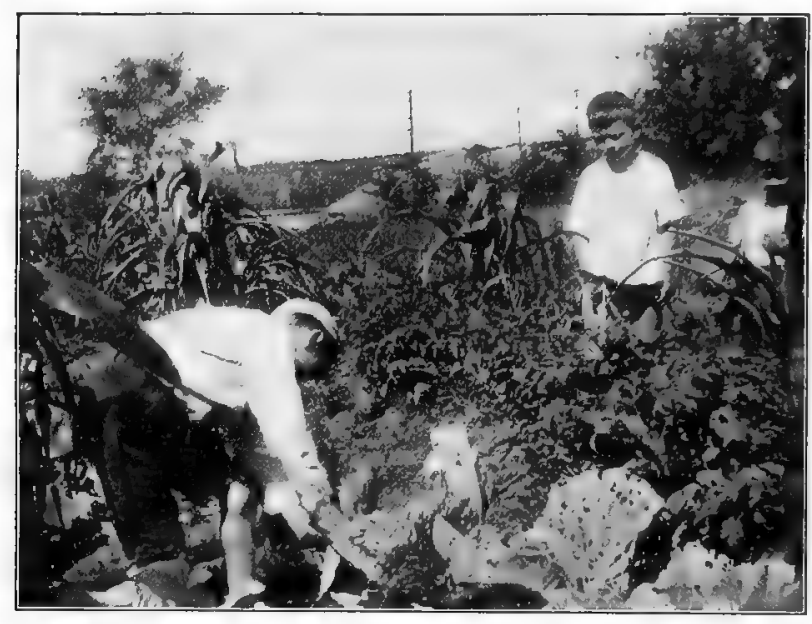

"WHO 'S WHO IN THE GARDEN"

weeds, overcrowding, insect effects, etc." To be sure, he does not advocate this as an ideal way of conducting a school garden. And yet it is not reasonabie that any believer in real gardening should with so little concern drop midsummer out of the calendar.

We should realize that a garden effects for good or ill a great deal more than the few individuals who run it. Having make-believe or half-cared-for gardens in its midst may spoil a neighborhood; even a few weeks of neglect will turn a 
spot of splendid promise into a breeding place for pests and a tangle of weeds and old papers. It is an ugly sight; surely no school can afford to countenance such a perversion of a good thing.

A study of the summer problem, however, shows that while young people are somewhat scattered during the holidays, it is rather the exception when a family of children go away for the whole vacation. Some are off for a fortnight and some for not so long. Suppose the children to be urged on by a purpose all their own, with a clear picture of what they wish to attain, and suppose they have the good luck to be near a good gardener, then there is a pretty good chance that the garden will hold its own.

On the other hand, it may be that the garden has sprung up at the wave of a teacher's magic wand, and that the children have, for the time being, caught by contagion a little of his enthusiasm; in such a case, what wonder that when the personality of the leader fades, the garden goes to the weeds. A garden carried on for the teacher's sake will be in no sense "a hardy garden"; this is because it has failed to touch the children's real desires. It is possible, however, for a teacher to help children organize so that they can go a certain length of time by themselves. One teacher, her first year, succeeded so well that the girls, during her absence of ten weeks, conducted the work themselves, it being understood that each one who went away for a visit should furnish a capable alternate.

In some towns garden work begun at the school, as a part of the regular school program, is continued during the holidays under the direction of a social settlement or a garden committee. Even when the summer work is carried on under the most favorable auspices, a change in management is a drawback. The change, too, is bound to occur when the 
work most demands a steady hand. Some children are sure to be upset by the irregularity, and drop out. Better, so far as continuous gardening is concerned, will be found the plan adopted in the city of Cleveland, and also at the Children's School Farm in New York, where a garden teacher and curator, with assistants, oversee the work the year round. The time is sure to come when in a corps of teachers it will be understood that certain ones are to take their long vacation in the summer and others in the winter. Each section of the city or countryside should have within access a demonstration garden, with a consulting gardener at the head who would understand the difficulties prevailing in the neighborhood, where questions about home gardens might be answered and puzzles solved, where seeds and plantlets might be sold for a trifle, and where the surplus vegetables might be regularly bought. Great things can be accomplished in a neighborhood where such a model garden is identified with the interests of home and school, each playing into the hands of its partner.

The records of school-garden events may be made in various ways. Sometimes the important notes are kept by a secretary elected by the class.

The diary that follows happens to be written by a member of a garden class in a somewhat closely settled suburb of Boston. It is one child's account of the incidents that inter ested him in the school garden during its opening year. Far more ambitious plans were worked out later, this school being one where the children formed voluntary partnerships, thus heightening the pleasure of labor and opening the way for interesting and ingenious enterprises. The school garden passed into competent hands during the summer, but, as in so many cases, its connection with the school ceased in June, causing the sort of break that we have already been 
regretting. The story stops then, too. It is a pity, for we should like to know more about the Allston garden, its genial neighbors, and the writer, aged nine.

\section{SCIENCE DIARY 1}

September 28, 1904 . I went out in our garden and observed caterpillars, mosquitoes, slugs, and other insects. When I was through, I brushed some plants and a lot of mosquitoes flew out.

October 28, rgo4. To-day we had some men come and make our garden larger. They used the adz and the spade. 'They cleaned our rubbish pile away.

October 28, 1904. To-day I was getting leaves in Mr. Bird's yard. The other boys were in the garden gathering stones and raking leaves.

November 3, rgo4. Dr. Field, a professor at the Masșachusetts Institute of Technology, came to prune our trees. He said, "there are three reasons for pruning ( 1 ) to make it bear more fruit (2) to make it bear larger and better fruit (3) to make the tree look better." $\mathrm{He}$ then showed us his saw. It had a blade on one edge to cut large limbs and a blade on the other edge for cutting small limbs.

One of our boys climbed up the tree to cut off high limbs, when Dr. Field was here.

December Io, I904. I was out in our garden planting grains. We put them in the corner by Mr. Bird's house. The grains were winter wheat, rye, and oats. We also planted some vetch.

December 20, 1904. About this time we had some men come to cover our garden with stable manure.

March 10, Igo5. Mr. Crawford gave us some garden boxes. They had no drainage. We had to make an artificial drainage because the ground would look very muddy. It was made by first putting into the boxes some large stones, then small stones, then crock, then sand and soil.

We planted some seeds in our garden boxes. They were lettuce, cabbage, cauliflower, tomato and pepper. The lettuce seed is long and narrow, but is very small. The cabbage seed is round and brown. Some boys of our class with me, were digging sand for our garden boxes.

1 No corrections have been made in this exercise. 
We were digging in the corner by the school wall. After we were digging some water came through the fence. The boys piled leaves on it and tried to stop it.

March 16, 1905. To-day we began digging a hole for a cold frame. The hole should be about ten feet long and about three feet in width.

March 17, 1905. We have tried to fit the frame to the hole. The hole was too small for the frame so we had to borrow the pickax from the City Fire Engine House again and make it larger.

We have noticed that the lettuce has come up. It has long leaves like this. It is all green.

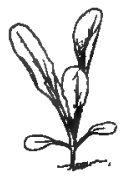

March 2I, 1005. To-day we had a large snowstorm that put us back in working on the cold frame. It filled the frame way up.

March 22, 1905. We had a visitor to-day. It was an alligator. It was sent from Florida to a girl in our room. It was about one foot long. It had a hard back. We jerked the box it was in and it snapped at us.

March 23, rgo5. A boy in our room went over to Mi. Bird's house and asked him for some manure for our cold frame. He said "Yes, would you like the dark or light manure?" We said, "We would rather have the dark." We brought over four or five loads in the wheelbarrow. The last load was light manure.

March 24, 1905. This morning some men from the schoolhouse commission were sent to cut off the browntail moths. We had some brought in to be put in a bottle for us to observe them. We have a piece of cheesecloth over the jar.

March 27, 1905. The tomato plants and the pepper have come up. All of the plants are up. There is only one specimen of pepper up.

March 28, 1905. The baby caterpillars are out and are crawling around the jar. The moth has not yet come out.

Marh 29, I905. Some boys went over to Wheeler \& Brown to get some loam. They are florists. We bought one dollar's worth, which was two barrels. It was brought in a team. One barrel was put in the cold frame and the other under the fourth window. Mr. Brown came in to see the plants in our garden boxes.

March 29, Ig05. This noon two boys went to the pottery to get some flowerpots. The man in the office showed them some pots but they were too large. We then got smaller ones for ten cents a dozen. The pots are three inches in depth and two inches and one half in diameter at the top. We bought five dozen. The men gave us eleven extra. 
March 29, I905. To-night some children stayed after school to transplant the tomato. The pots were filled with loam. There was only one tomato in each pot because the pots are small and the plants will grow large. We had seventy-one pots in all and fifty-four tomatoes. We have seventeen empty pots.

March 3r, 1905. To-day we finished our cold frame. In the morning some of the boys planted seeds in it. The seeds were lettuce and radish. The lettuce seed is long, narrow and black. The radish is round and of a reddish brown color. The seeds were planted in furrows about a

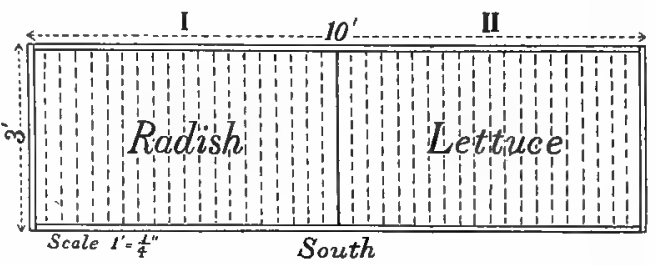
quarter of an inch deep. The furrows were three inches apart. This picture is a plan of the cold frame showing how the furrows were made.

The boys planted radish in the cold frame nearest to the corner of the portable. The lettuce seed was planted further along in the cold frame toward the wall.

In the afternoon the janitor put on the glass windows for us. The boys watered the seeds, after they had been covered over with the soil and we left them to grow up during our two weeks' vacation.

This afternoon Miss Withington came out. We read some of our diaries to her and she liked them very much. We showed her our catalogues. At three o'clock we went out in our garden and scratched off the old manure off of the crocuses and tulips.

To-day we also raked a part of the large garden. It was the part near the corner between the school and the portable.

April 10, 1905. When we came back in vacation we noticed the crocuses had come up. They have a bright yellow color. The tulips have come up but have no flowers. They have come up about two inches in height.

The plants in our cold frame are up. They are radish and lettuce. We have two boys that tend to the cold frame and open it in the morning and close it at night. I am the one to see that the cold frame is well watered.

The pepper has come up indoors. The grains out in the garden have come up. They are wheat, rye, and oats. We planted them last fall. 
April 25, 1905. Last night we soaked some peas in water. I noticed that they have swollen and smoothened out. I have also noticed that the radish in the cold

May I, I905. The They are this shape. had to thin them out. others we thinned out

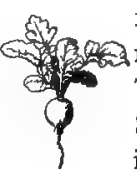
frame has turned red at the bottom. radishes have turned broad at the root. The plants were very crowded so we Some we put next to the peas and the in the cold frame.

May 2, I905. To-day we transplanted the rest of the tomatoes into the small pots. There were sixteen This is a picture as it is to-day: the first leaves and the others are grown since the first had spread. leaves and quite a few others. The and the first are smooth around the

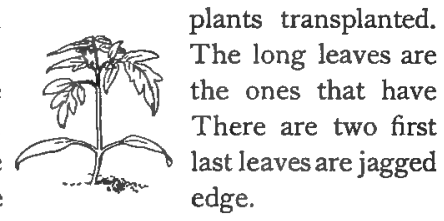

May 3, 1905. Miss Withington came out to see our garden. It was at recess and we went out in the garden. We planted beets in with the radishes because the radish will be out and the beet takes till fall to be ripe. We then left a path for us to get at the radishes and beets. We then planted onions in two rows. The onion seed is round and black. It is small and has a rough surface. The beet seed is very rough. It is a brownish gray and is about three sixteenths of an inch in diameter.

We have received a new hose from the janitor. It was put on this noon.

May 4, I905. This morning we went out in class sections to transplant our cabbage next bed to the onions. The cabbage is six to eight inches high; we planted them to the description of Miss Withington. They were set about twenty inches apart. We then transplanted lettuce in among the cabbage by the Italian method.

May 4, 7905 . This morning I was out in the garden. We each had a garden two feet wide and half the length of the large garden. We had partners which had a garden two feet wide on the other half.

We planted beans, parsnip, turnip and cucumber. We have two sections, the first section have the odd numbers of the garden and the second the even numbers. I had turnip, cucumber and beans. It was so windy we could not do the planting so Miss Homer planted them and we made the furrows and covered the seeds. The cucumber seed is like this :

I did The beans look like this : not see the parsnip and The turnip is like this: cannot describe it. 
May 8, 1905. To-day we noticed the peas had come up and they had to have the earth scratched around them because there were lumps of earth and they could not push through. They looked like this when we took off a lump of soil.

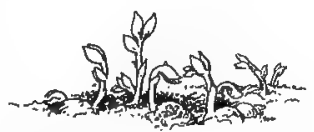

The tulips have come up and they were planted near Mr. Bird's fence toward Cambridge Street. They are white, yellow, red, and striped. They look like this :

May 23, rg05. To-day we planted lettuce, radish and beets. We planted them next to the transplanted lettuce which is in the second section's side near the trees toward Mr. Bird's fence.

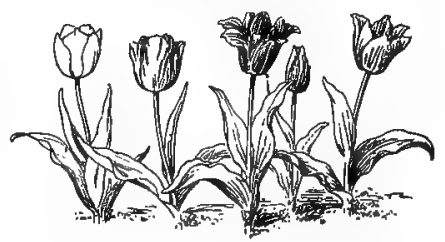

May 24, 1905. To-day we scratched the earth around the small plants in our own garden.

We also planted peas next to the grass by Mr. Bird's fence near the grains.

May 25, 1905. To-day we were cleaning up the garden. I was in the crocus bed scratching the soil, the ground was very hard and was hard to soften. After I had softened the ground I cut off the leaves near to the ground.

May 26, 1905. This morning we boys were planting spinach in the shade. We made three furrows in the second section's ground. We planted squash and corn in the sunshine. The squash and corn needs the sun and the spinach needs shade. We then sat down and read "Alice in Wonderland" under the trees.

May 29 , 1905. I noticed to-day our beans were very large, and our peas, radishes and lettuce in the second section are up. The peas look like this.

June 5, 1905. I went out this morning to look at the garden. The spinach, corn, squash and the peas are up. The peas were up before, but the leaves have come out. The beans are up about three inches.

The soil has been very dry for a long time except on Friday when there was a little shower for a few minutes.

June 6, 1905. My garden, No. 18, Second Section, has planted in it:

$\begin{array}{llll}\text { peas } & \text { squash } & \text { lettuce } & \text { radish } \\ \text { turnip } & \text { onion } & \text { cauliflower } & \text { cucumber } \\ \text { beans } & \text { parsnip } & \text { cabbage } & \end{array}$


Mr. Bird's fence

\begin{tabular}{|c|}
\hline stock \\
\hline phlox \\
\hline stock \\
\hline Scale $I^{\prime}=\frac{1}{4} "$ Edge of garden \\
\hline
\end{tabular}

PLAN OF THE FLOWER GARDEN NEAREST THE STREET Planted June 9

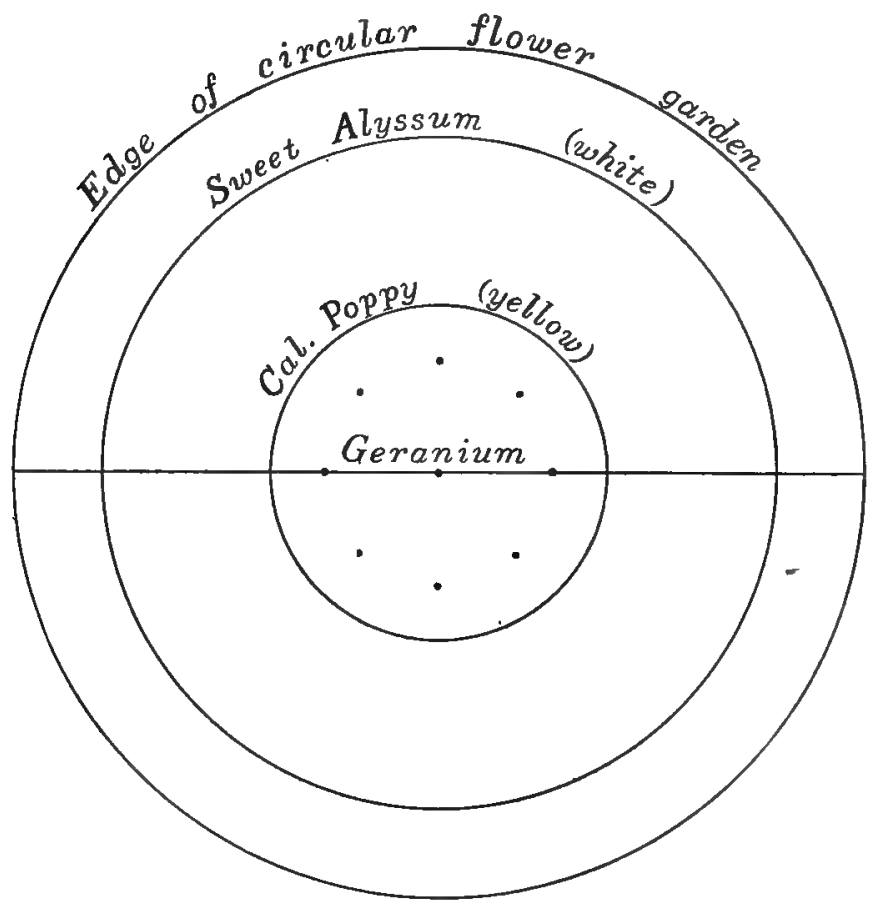

PLAN OF THE TWO CIRCULAR FLOWER GARDENS

Planted June 9 
June 14, 1905. To-day I was out in my garden. My peas are 6 inches, squash 4 inches, radish 2 inches, cabbage 7 inches, lettuce 2 inches high and $6 \frac{1}{2}$ inches long, cauliflower ro inches, beans 7 inches, turnips $\frac{1}{2}$ inch, and onions $2 \frac{1}{2}$ inches.

I have been out and measuring my plants.

Tyler S. Rogers

Age, 9 years 10 months 


\section{CHAPTER XIII}

\section{THE NEW AGRICULTURE}

We are beginning a new agriculture, not continuing an old one.

LiBERTY H. BAILEY

The best thing school gardening does for children is to help prepare them for their larger life in the world; and gardening will have accomplished this if only they have mastered one single lesson: how to attack a simple problem in scientific fashion and work it out coöperatively. To thus work out such a problem demands far more skill than would at first appear. It means, above all, that children will have been strictly schooled in leadership and in loyalty to leaders. The power so gained can be applied in after life a dozen times a day.

Next in importance comes enthusiasm for the soil itself. This, once aroused in the hearts of children, will continually bubble up. Children love their school garden, and they work in it like bees; but the real test of a good school garden is the good home garden. Its season's work can never be more genuinely measured than by the dozens - possibly the hundreds - of little home gardens that spring up within a short radius of the parent plot. These may be the means of waking up a whole neighborhood, for they will show conclusively how the use of odd moments - one short half-hour a day - will afford armfuls of fresh vegetables for the family table, and often a supply besides for neighborhood sale.

But a teacher does not content himself with accompanying children to the boundaries of the wide world and there 
bidding them good-by. No, he follows the different trails as far as eye can reach; and when these blur and disappear in the distance, he knows well enough that some day the youngsters will be returning to tell him their adventures. A master not only welcomes these youthful explorers; he actually depends upon them to bring home to him bits of new knowledge. Proud of their confidence, and yet humble enough to learn from them, he then enriches his own personal experience by the results of their quests. In this way a teacher leads not one but a hundred lives. He needs to; for whatever he may be titled in the catalogue or dubbed on the ball field, his real business is getting his pupils ready for the work of life.

Thus the fruits of a garden director's efforts will not have properly matured unless he keeps in view the possibility of a country life for at least some of his children. Even for those growing up in a city's midst, provided they are caught young enough, tillage of the land is seriously to be recommended. The fact that one of the first boys of the Rice School garden, one who had never lived out of the so-called slums, is now a graduate of the Bussey Institute, and a full-fledged gardener, makes us believe that such a record as his may inspire other city boys to similar ambitions.

But what sort of world is this which a bright lad with a yearning for outdoors proposes to enter? What does the farming life require of him, and what does it give him in return? It is a teacher's business to find this out, beyond the possibility of a mistake, before he is ready to advise young candidates.

It must be owned that the agricultural situation in these last years has puzzled the wisest. Agriculture is at present passing through a wonderful period of reconstruction. So serious are the changes now being wrought, that a distinguished 
member of the British Association has recently said: "As the nineteenth century had its industrial revolution, so will the twentieth century have its agricultural revolution."

So swiftly, too, are these changes rushing upon us that, in the words of the Looking-glass Queen: "It takes all the running you can do, to keep in the same place. If you want to get somewhere else, you must run at least twice as fast as that."

It certainly takes a high rate of speed, in these days, to keep pace with agriculture. It is hard enough for the individual to adjust himself to the new ideals and conditions, but still harder for a whole community. Two contradictory elements belong in every locality; it is always so. Discuss farm pleasures and profits with a philanthropist or a social worker and the response is quick and enthusiastic; he sees a vision, even though he does not know exactly how to realize it. Try, however, to talk with some grizzled farmer as you jog along with him behind old Nell, and ten to one he will ominously shake his head. He has never dreamed; he is too "practical." To your disappointment the topic is closed almost before it is begun. These instances show how the past and the future overlap in the present. The prophecy of success confronts the story of defeat. It is the educator who must look squarely at both.

In agriculture, as in everything else, the big things attract attention first. Merely to hear about them makes the pulse beat quicker. Some of these achievements impress us as we whiz past them on the long-distance train; some of them we may be lucky enough to visit; plenty of them we can read about. Among the number are the ten-thousand-acre wheat fields, with the thirty-two-horse-power reaper, the great rainless farms, the wonderful stretches of built-up soil. They include the acres of glass frames that, like ponds in the distance, 
flash back the sunshine, and the houses where plants are being grown by electricity. Besides, there are whole fields devoted to some of the latest fashions, so to speak, in crops: alfalfa, cowpea, crimson clover, and macaroni wheat.

The perfection to which each tract has finally been brought leaves no doubt that the plan has been worked out by a highly trained person. Indeed, if we are struck by any one thing everywhere, it is that success follows in the wake of applied science.

What does all this cost? The quotations regarding the expense of equipping a great modern farm are certainly impressed upon us. Therefore the business ability and skill needed in conducting it must be that of the expert. A manager's equipment, then, must include both scientific training and a knowledge of men and money. It may be new to some that a successful farmer must be a successful business man.

While still under the spell of these magnificent ventures, another question arises: What relation do these great farms bear to the development of our country as a democracy? The answer is that the larger the farm, the greater is likely to be the amount of hired labor. Hired labor means workers that are controlled by authority but are largely exempt from responsibility. Such a class is a weed in the garden of democracy; it must be rooted out. Society, because it gains by small and loses by great ownerships, is ready to help cut up large estates into little farms.

Some gardeners have been quick to see their chance. A man of science knows that he can, in many respects, score on a little farm as well as on a large one. In obedience to this theory such experts are multiplying fast, and they are reaping their reward. From mushrooms to medicinal herbs, tiptop produce never goes a-begging. A market gardener in the 
neighborhood of New York tells us that he can actually get whatever price he asks for his strawberries and early peas.

One thing more must be taken into account. To-day a producer is decidedly looked up to in the community; seldom in history has there been a time when the progressive

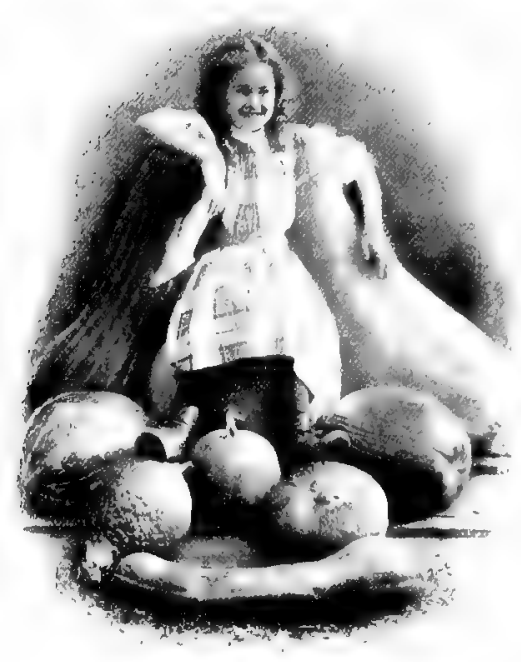

WHEN THE EARTH IS TREATED KINDLY gardener has been respected as he is to-day, and never has his hand been so warmly grasped by scientists and business men. Still more encouraging, this industrial comradeship is not prompted by patronage or philanthropy ; it merely acknowledges the intrinsic worth of those who are working the soil with brains as well as with brawn. The sum total of experience shows that it is the trained man, whether working on a gigantic scale or on a small one, who, other things being equal from the economic standpoint, wins out.

Yet, in spite of this general truth, a would-be expert does sometimes fail, no matter how quick-witted or how scientific he may be, because final success depends upon a market. Even the optimist, who from his lookout loves to call "All 's well!" and who predicts, for small lands intensively cultivated, triumphs that are little short of miracles, is shrewd enough 
to see that these returns are only possible under the wellorganized conditions of coöperative farming. The crux of the matter, then, appears to be association with others.

So, after all, to be a scientist and to stop there is not enough; one must be an organizer as well. And the simple logic seems to be, either keep close to town, notwithstanding excessive rent, or combine with other producers. Would there not be twofold wisdom in doing both?

Turning now from the expert, - the somewhat rare man whose success is practically assured, - let us consider for a moment the average small farmer of to-day and the place he occupies in the community. $\mathrm{He}$ is the man we pass on every country road. Let us picture somewhat in detail the life he leads. His farm is somewhat isolated; he usually owns more land than he can properly cultivate, for he hires little or no help; its very extent works against his best interest, since he has not the ability really to excel in anything. $\mathrm{He}$ trades in the village; seeds, for example, he will probably buy at retail. In addition to paying high rates he usually obtains neither a large choice nor a fresh stock. Thanks, however, to the work of the agricultural stations, where tests are made free of charge, no farmer nowadays need remain in the dark as to the quality of either seed or fertilizer. Next arises the question of implements. These must be suitable for the work proposed, even if they are not the latest inventions, or else, in the midst of the rush season, our friend will be plodding a week at what otherwise could easily be done in a day. The heavy work of a place, such as the teaming of muck and manure and the plowing, always adds greatly to the first cost. Still, for a small farm, - too small a farm, you will probably say, - a man naturally hesitates before indulging in plows and patent planting and weeding machines, new patterns of which are always being advertised. 
He knows very well that the plow will be required for at most a few days, and the harrow for certainly not longer. Spraying machines and large forks and spades, although at times imperative, would only be brought out occasionally and might not be used more than two weeks, all told. So, what with the delay of too few tools on the one hand and the extravagance of needless expense on the other, it is a toss-up between the rocks and the whirlpool.

Let us suppose, however, that our farmer has managed to get rich crops without too great an outlay. He has hit the happy medium of buying a few first-rate tools and hiring some of the heavy labor. It is safe to say, then, that the stuffs he has raised will generously feed the family, and allow, besides, a good deal over. This overflow must find sale, if possible, in his own neighborhood. If not, the packing and shipping of perishable goods to a distant market seriously complicates the whole business. Transportation all too often swallows up the profits; and so, little by little, our producer must withdraw from a losing game. Not only that; the habit grows upon him of shutting his eyes to opportunities of every sort, until he becomes too timid to take even the most innocent risks. He settles down and becomes a perfect mollusk.

Nearly every countryside furnishes illustrations of such conditions. One illustration that recently came under the writer's eye is the "petering out" of the strawberry business in a New Hampshire county. The township lies about one hundred twenty-five miles from Boston, plus four miles from a railroad station. At such a distance country produce might be supposed to be practically free from "down-country" competition. Besides, at the height of the strawberry season summer residents arrive, eager to feast upon a generous diet of native vegetables and fruit. The prices for strawberries run as follows: native berries fifteen cents per quart, sold 
"to oblige" at the various farms, but not regularly delivered even in the village centers. These berries compete with Boston berries, two quarts for a quarter, which are sold at the village provision store, or will be delivered within reasonable limits. Result: the village store is stocked with city produce. Naturally it takes the easier and steadier source of supply; and yet this very township could not for a moment be described as the "hilly, stony, exhausted margin of cultivation." Quite the reverse; it is a country where, nearly every year, excellent apples rot on the ground, and where blackberries and raspberries hang shriveling on the bushes, or fall, dead-ripe, for lack of picking. Meanwhile, the scattered farmers, land-poor, drudge from dawn till dusk to make both ends meet.

At first, one is always puzzled to explain why this stream of "green groceries" invariably flows in one direction, countryward, and in a direction exactly contrary to what might be called the natural laws of economic gravitation. But the grade of country produce explains this. Quality, after all, is the thing, and far back in the country this is rarely high enough to bring the fancy prices which would cover transportation ; and, of course, rates which a railroad might make for an association of growers would by no chance be offered to the single farmer. Little wonder that there is depression in farming circles.

The cure of any trouble, whether local or national, is often best reached by looking beyond our own borders. So let us turn our attention for a moment to the present agricultural situation in Europe. The Man with the Hoe is fortunately not an American product, and yet who shall say that he cannot teach us something? Surely the story of his uplift may act upon our own countrymen as a muchneeded tonic, for many an economic danger which has 
threatened America has first forced itself upon the mother countries. Let us follow for a little the main thread of their agricultural history.

A gloomy period of discontent, which may truthfully be called Darkest Agriculture, has long been prevailing among the small farmers all over Europe. About ten years ago the storm which had been brewing burst. Its cause was twofold: it arose from the farmer's ignorance and from his isolation. Which of these evils was the worse it would be hard to say, because the isolation from which he suffered was not purely geographical. Isolation is too often a state of mind; jealousy, suspicion, and greed have long been recognized as among the most perfect of human insulators.

It appears, according to John Graham Brooks, that there was scarcely a district in all Europe where the small farmer had not been for years systematically fooled because of his economic and social weakness. The past records tell gloomy tales of extortion, and in some places these conditions have continued till the year 1905. Little more than a slave, the farmer was kept down by middlemen who worked his credulity for all it was worth.

Especially in regard to fertilizers, where even a primer of chemistry might have saved him, he proved an easy mark. One story reads much like another. In Essex County, England, for instance, it was discovered that every year farmers were being tricked into buying artificial manures, literally of no value, at something like twenty dollars per ton. In much the same way worthless seeds were palmed off upon them. No wonder that these distressing conditions, so widespread and so steadily on the increase everywhere, caused a fever of unrest. At last human nature could endure no longer; a universal cry went up for a radical cure. The response came from social reformers who had been for years 
working at such problems. ${ }^{1}$ Scattered though they had been in different parts of Europe, they all arrived at the same fundamental conclusions. What is more, the remedy which they offered has had virtually the same effect in every country that has begun to regain its social and agricultural health. And what is the formula for this golden discovery? It sounds simple; it is the cure by coöperation, and the basis of its efficacy consists in restoring to the tillers of the soil their sense of wholesome dependence one upon another.

The working out of this new-old principle marks the beginning of a superb movement; in fact, coöperative agriculture has begun to sweep across Europe with the onward push of a great wave. Even yet it has probably not reached the high-water mark. In Denmark, a country where the agriculturist has so fully come into his own, coöperation was first attained by a determined uprising of the people ; in Hungary it originated with the government; while in France and Belgium it started as a reform headed by a handful of keenvisioned and devoted Catholic priests. This binding together of whole communities for progress in agriculture, which has in every case adapted itself so perfectly to the peculiar needs of each country, makes an impressive chapter in the history of our time. The story cannot fail to thrill the reader.

The advance of coöperative agriculture in Belgium alone shows the scope of the movement. A very noble type of priest, the Abbé Mellaerts, in about I 890 threw himself into it heart and soul. His attention was first aroused by the little coöperative banks among German peasants. The business success of these banks, and their moral influence, so impressed him that he determined to found on the same lines an agricultural league. Within fifteen years this league counted four hundred thirty active branches, with thirty-two thousand

1 Kropotkin, Fields, Factories, and Workshops. 
members. There could be no better statement of the fundamental object for which this league stands than the third article of its statutes: "The Agricultural League has as its object the promotion of religious, intellectual and social progress among its members and the safeguarding of their material interests in order to establish a class of strong Christian agriculturists."

To judge how the several departments have grown, one needs only to examine the development of the dairy business. At first coöperative dairies formed an insignificant branch of the work; and yet, although in I89I there were only eleven dairies, in 1905 there were in operation four hundred ninetyeight. Postcamp and Antwerp, moreover, set up coöperative mills; at present they raise seeds and manufacture oil cake. Warehouses have been established everywhere.

One after another the troubles arising from all these long years of ignorance and misunderstanding have been overcome. The coöperative buying of fertilizers, machines, and other supplies was comparatively easy to manage; but the marketing of produce on a grand scale is a difficult matter and in every case has proved a severe test of loyalty to the federation. Within two years this last upward step has been triumphantly taken : namely, that of selling members' products to an outside market.

The federation provides that all the fertilizers bought by the little associations shall be carefully tested by expert chemists. This is but an instance of how, as one authority ${ }^{1}$ puts it, "coöperation grown strong puts the man of science in the field."

The local associations not only employ scientists to test and purchase manure and feeding stuffs, but they organize agricultural credit, mutual insurance, and all forms of banking

1 John Graham Brooks. 
and saving. An idea of the business done by the Agricultural League may be given by a few figures. In the year 1906, for example, the league bought for the use of its affiliated societies $28,000,000$ kilos of chemical manures, besides more than $25,000,000$ kilos of cattle foods costing over $\$$ I, $, 000,000$. The same year its banking business had grown till it reached a turnover of more than $\$ 2,000,000$. The amount of insurance and savings handled by it has increased lately to enormous proportions. Throughout. Europe, in the places which these societies cover, the material gain has amounted to from 20 to 40 per cent. What such opportunities for mutual benefit may mean to a single family is shown by a concrete example: On one farm of twenty acres, for instance, coöperation has easily saved a margin of $\$ 480$ each year. Think what this might add to the comfort of living!

Great as has been the economic gain, the moral and social value, some say, is even higher. This is due to the fact that a successful "coöperative" truly educates its members. This should cause no surprise, for it commands applied science, it commands honesty, it drives out suspicion of one's neighbor, and in its place puts confidence. More than that, "it includes the ever-enlarging good of others as a part of one's own welfare," says Mr. Brooks. In fine, its aim is to draw men together and not to separate them or antagonize them; its working hypothesis would seem to be science and brotherhood. Once born in a community, the social conscience is bound to grow ; new visions flash across the sight; before long the whole spiritual perspective becomes changed. The social causes, as opposed to the individual causes, of evil and injustice are for the first time shown up. Intolerance, whether ecclesiastical or political, appears in all its ugliness.

The present solidarity of the European farmers, which is to-day so remarkable, has, as we have seen, been reached along 
no easy road; it is hardly too much to say that they have been whipped to it by degradation and misery. Through discipline they are at last attaining self-respect, brotherhood, and economic prosperity.

These experiences from overseas set us thinking. We begin to suspect that the troubles of the agriculturist are much the same the world over, and that they may be traced to the same general causes. Let us turn this new light upon the situation at home. The condition of the average farmer of whom we have spoken is the culmination of events for years past. Looking back, we see a land of promise being ignorantly skimmed of its richness; on every side there is woeful waste of land and labor; and we see, in proportion to the resources of the soil, strangely low standards of happiness and opportunity. We see streams of boys and girls, who have been tutored by city-bred teachers to admire and long for city ways and occupations, moving steadily townward.

Of those left stranded on the old place, however, a large proportion are groping along by guesswork; their occupation has generally been taken up by chance, not by choice; they are impervious to new methods in science or business. But a greater obstacle to success than ignorance of scientific methods is the solitude which has often made an otherwise fine character cranky or, in country phrase, "stiffnecked." Who cannot bring to mind such a figure, at once impressive and pathetic? It is his obstinacy ("independence" is his name for it) that drags back every step that he would take toward progress and prosperity. In fact, even when "Farmer! farmer!" is sung out from one school child to another, it teases not so much because it points at ignorance or baggy clothes or at mere physical awkwardness as because it implies that peculiar and aggravating angularity of mind which remains sharp and unrounded from lack of sympathetic 
contact with men and affairs. This is not fair, you say; and yet how often is expert advice met by farmers with dogged silence, or sometimes with such frankness as "I don't want any book larnin'; nobody from Washington need tell me how to raise corn." There always appear on the scene, in slightly varying dress, the same old hindrances, — ignorance and isolation.

Still, how can it reasonably be expected that natures which for years have been chilled by a lonely, breadwinning life, and which perhaps have been further stiffened by local or family prejudices passed down with the farm (for a prejudice is sometimes as real as a mortgage), will suddenly warm to a coöperative suggestion? This would be asking too much. The effective use of coöperation, - its technic, so to speak, - can come only with practice.

And yet, is association for a common cause so artificial a means of attaining results? Is it merely a floating spar, to be clutched at in social shipwreck and then tossed aside when the unfortunates have drifted safely to shore? No; it is a force which underlies and shapes the whole structure of society. Possibly some of the phrases commonly used in connection with evolution, - " struggle for existence," "survival of the fittest," and other biological terms, - may be a little misleading; they may be responsible for the assumption that the great fundamental law of life is competition. There is really no foothold for such a belief, although no one would deny that competition has its place.

Within recent years research has brought to light the great social impulses that belong to all primitive peoples, as well as those social impulses shown to be dominant even among animals, - for animals enjoy many hitherto unsuspected forms of social life. ${ }^{1}$ Science, indeed, leaves no room for doubt

1 Kropotkin, Mutual Aid. 
that the instinct for coöperation, feeble though it appears at times, perverted though it may often be, is really firmly rooted in the heart of man. We are brothers all ; given half a chance and the brotherhood of man asserts itself. We will not yield here to the temptation of discussing how this instinct of the race has become dulled. True it is, no doubt, that the feelings of confidence and brotherhood are not so much blunted as stratified. Put in geological terms, each stratum would represent a certain distinct standard of living. According to this idea a person might readily understand the struggles and triumphs of those in his own stratum, but very imperfectly those of another. This may account for the sharp cleavage that often separates classes, shown by the lurking distrust of mankind found in the hearts of otherwise sympathetic and broad-minded persons.

Nevertheless, for whatever cause any of us may have failed to grasp the whole meaning of coöperation, the time has come when we should pledge ourselves not merely to the theory but to its practice. The test of loyalty to any principle is its effect upon behavior. But old habits persist; the full force of coöperative methods can only be learned by constant practice during the formative period of life.

We have shown in the foregoing chapters how children are enjoying the chance to work coöperatively in school gardening. Grown-ups see their opportunity in modern farming. A trained man is not only welcomed; he is sought. The land is calling for the right sort of men; it cannot get enough. We have already shown some of the qualities that such men must have.

It may reasonably be asked whether all this anxiety for our rural prosperity is quite justified. Of course, in the outworn farms of older countries there is need of thorough reform; but why should we, in a country rich and young, urge 
attention to these points? Our wealth has always been regarded as inexhaustible.

Nevertheless, no thinking person can shut his eyes to certain national calamities that are advancing upon us; unless we anticipate them we shall, before we know it, be overwhelmed. Two of these, in particular, may be pointed out.

It is not uncommon to hear from time to time that an entire crop for miles around is attacked by insects. These spread from farm to farm, from county to county, from state to state. They can be destroyed by prompt and intelligent measures, but only by concerted action on the part of all the inhabitants. Take, for example, the recent attack of the cotton-boll weevil in the South, against which active warfare is being waged. The ravages of pests like these leave in their wake poverty and desolation; sometimes whole districts have been ruined.

A further peril is foreseen by statesmen. They picture the land drained of its best men, skimmed of its nutriment, and its crops destroyed by pests. These conditions must inevitably affect the food supply of a great nation. Failing to produce enough food, we shall have to be fed by foreign peoples either within our borders or outside, - perhaps both. The danger to the country at large is that our farm lands, once deserted, may be quickly taken up by immigrants who, bringing with them distinctly lower standards, will, before they can be assimilated into our national life, get control of it and us.

Those who watch the times are telling us these plain truths in one way or another every day. What measures, if any, are being taken to avoid these dangers? With varying success the grange and the farmers' institutes have been constantly raising the level of country intelligence. Happily much is already being done by the Agricultural Department at 
Washington, by the experiment stations, and by the agricultural colleges all over the country. Instruction has been persistently given by means of bulletins and leaflets prepared by experts. The results, however, have been somewhat disappointing, for there are regions where only about one per cent of the farmers have made any connection with these centers. New plans, therefore, are on foot. The experts have learned to depend no longer upon reaching farmers by means of printed bulletins. They are opening correspondence courses with individuals and clubs. They are sending members of their staff into certain neighborhoods as social engineers. These men and women bear no official title, but their mission is to carry on model farms, to win the confidence of their neighbors, and to lay the foundation for closer connection with the colleges. With the assistance of the railroads they are sending out "Better-Farming Specials," as they are called, - trains ingeniously equipped for agricultural teaching, which stop, as advertised, at certain central points, for demonstration to the farmers, who gather from miles around. Moreover, they are helping the farmers themselves to organize in associations for better produce and for scientific breeding, after the methods of the Danes. Some of the conspicuous coöperative organizations already doing effective work among us are those of the fruit growers in the West, of the cranberry raisers in New England, and the coopperative dairies. At present, organizations of this sort are all too few in America.

There is no doubt that the most hopeful sign of all is the way in which the children are being won over to the interests of country life before they begin to feel the pull of the city. The corn and potato clubs started for children by the government, offering definite honors to the winners of certificates, might alone be said to mark a new era in rural neighborhoods, for the reason that they recognize the influence that 
a band of youngsters exerts in the community. ${ }^{1}$ In short, no factor is neglected which can contribute to the betterment of country life. Everybody is needed; all forces are pressed into service, - the trolley, the telephone, the community church, the model kitchen, the model garden, and the country school. Indeed, the country school, around which so much is beginning to center, is probably destined to be the leading school
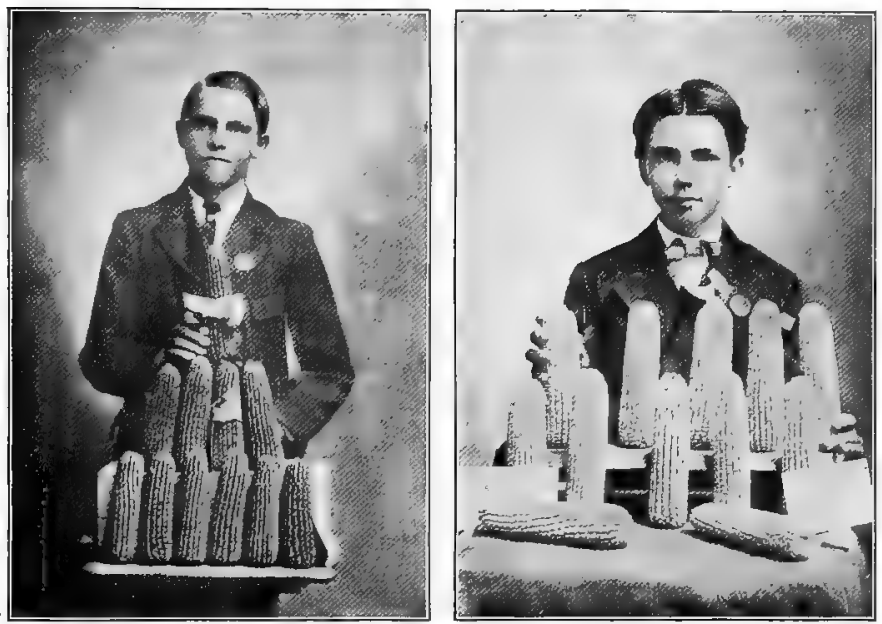

TEXAS BOYS AND THEIR PRIZE-WINNING EARS OF CORN

in the land. It will train its students for a large and generous life in the country, and there, through interest and success, they will be held.

The broad fields east and west are calling for young people who are in love with the great outdoors. Idealists, above all, are wanted, for the true idealists are the ones who can "toil "terribly." They are those who, in order to make their dreams 1 See Boys' and Girls' Clubs, Agricultural Bulletin No.385, February, I91o. 
come true, can harness themselves up and tug and pull. Our country needs, moreover, young people who so keenly want to get at the truth that they will tease nature with their questions and never stop till they get the right answers, with all the proofs. Especially does it need those rare persons who know how to intensify their own working power by joining with others in a common cause. This is the essence of the new agriculture.

And now what does the new agriculture give in return? A wholesome life: sound lungs and a good appetite, together with the means of satisfying it and of providing for others liberally. It presents a business.opening, not always of the first rank from the money standpoint, to be sure, but first in returns that are better than dollars. It offers a life brimming with opportunity. The days are not long enough for the marvelous tales and the wonderful songs that Nature, the old nurse, sings when, set free from anxiety and from too much drudgery, the practical farmer and the poet meet on common ground.

Again, agriculture gives a life scholarship in the best laboratory that the world has ever known, - a workshop where every investigator may confidently look forward to the exhilaration of discovery, while the discovery itself will add directly to his own and his neighbor's welfare. It would be hard to find another calling which offers to workmen of all grades such genuine possibilities. Is it not true that most breadwinners expect little else than - like dull, superannuated car horses - to trot monotonously along the track laid down by some corporation?

Finally, the true agriculturist is a pioneer. He discovers; he subdues. A campaign against the stubborn, subtle forces of the earth demands sacrifice, fortitude, heroism. These qualities make the martial spirit, - that love of battle which, it is said, cannot and must not be tamed within us. ${ }^{1}$ But

1 William James, Moral Equivalent of War. 
there is a difference: in agriculture the army marches not to possible destruction but to actual production. In it have enlisted the soldiers of the soil. To-day this thought is taking visible form. It is the birth of a new agriculture. We are already seeing what has well been called the Agricultural Renaissance.

The hope of the new agriculture centers, as we have seen, in the children. They bring to school natures courageous and unspoiled. The germ of the scientific spirit within them is surely active enough; it lies in their everlasting curiosity. Confidence in comrades is at its highest. The social instincts of childhood, also, are irrepressible. Beginning with short and easy steps, it is for the educator to develop these precious impulses in children to fuller and larger conceptions of adventure, of leadership, and of solidarity. As they grow older and enter practical life, they seize upon coöperative ways and means with such zest as only young people can show who have tried team play in their studies. For they know - they have learned without any telling - that a self-organized team is the best dynamo ever invented for getting things done. They realize the supreme happiness of working together. They know, besides, that through mutual aid the strength of each, be he weak or strong, is the strength of all. If not taken in too narrow a sense, competition might be called the tug of war. Coöperation, then, is the tug of peace.

The equipment demanded by a youngster of ambition and aspiration now becomes clear. He must be trained from the beginning and throughout his entire school life in the methods of both science and coöperation, so that he may develop the power of controlling natural forces and of leading men. Loyalty, leadership, science, are the three vital qualities that insure his success. Gardening, then, worked out at school after some such plan as has been sketched in these pages, 
will be a powerful lever to raise agriculture - rightly viewed, the most rewarding of occupations - from the humble plane, where it has long remained, to the heights which it is destined to command.

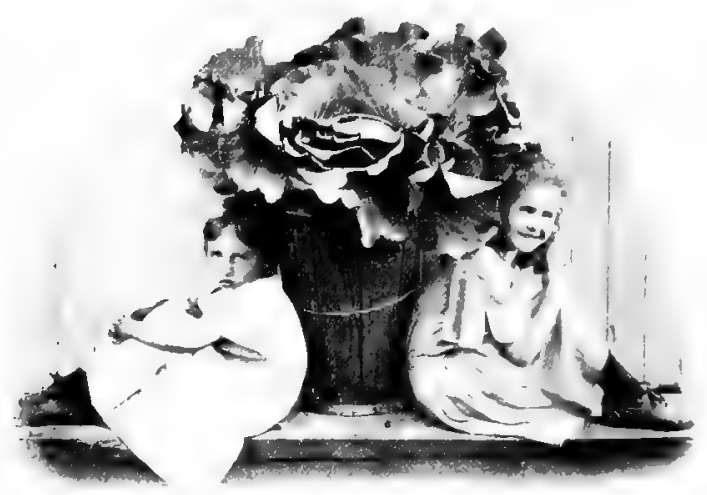




\section{APPENDIX}

\section{A SHORT LIST OF USEFUL BOOKS}

\section{Books on Garden MaKing}

Bailey, Liberty H. The New Cyclopedia of Horticulture; Practical Gardening; Principles of Agriculture.

Bailey and Hunn. The Amateur's Practical Garden Book.

Brooks. Soils and How to Treat Them.

Fullerton, Edith L. How to Make a Vegetable Garden.

French, AlLEN. A Book of Vegetables.

GOodrich, Charles L. The First Book of Farming.

KIng, Franklin H. Text-Book of the Physics of Agriculture; The Soil.

LipMAN, JACOB G. Bacteria in Relation to Country Life.

Powell, EDWARD P. The Country Home.

Weed, Clarence M. Insects and Insecticides.

Books of SPecial InTerest to Teachers

Emerson and Weed. School Garden Book.

Green, Maria L. Among School Gardens.

Hampton Institute. Nature Study Bureau Leaflets.

HAYES. Rural School Agriculture.

HoDGe, C. F. Nature Study and Life.

JACKSON AND DoUgherty. Agriculture through the Laboratory and School Garden.

Jordan, Alice. A Brief List of Books about Gardening for Boys and Girls. ${ }^{1}$

Massachusetts Agricultural College. Public School Agriculture; Suggestive Exercises.

Osterhout, Winthrop. Experiments with Plants.

Sargent, Frederick Leroy. Corn Plants.

-1 Published by Boston Public Library. 
Books showing Gardening in its Relation to Life

Bailey, Liberty H. The State and the Farmer.

Bailey, Liberty H. The Country Life Movement.

FAY, C. R. Coöperation at Home and Abroad.

Hall, Bolton. Three Acres and Liberty.

Kropotkin, P. Fields, Factories, and Workshops.

Pratt, E. A. Organization of Agriculture.

Hagrard, H. Rider. Rural Denmark.

SCOTt, Colin A. Social Education.

Underwood, Loring. The Garden and its Accessories.

Pamphlets That MAY BE SEcured Free of Charge

I. Bulletins of the experiment station of your state.

2. Bulletins of other states.

3. Publications ${ }^{1}$ from the Secretary of Agriculture, Washington:

One complete set of Farmers' Bulletins.

One copy of the list of bulletins for free distribution.

One copy of the list of publications for sale.

One copy of reprints of the field operations of the Bureau of Soils for each of the areas surveyed in New York state.

Copies of Farmers' Bulletins Nos. 44, I 23, I 43, I 54, I 57, I 87, 203, 2 I $8,229,255,260$.

4. From the Weather Bureau :

Daily weather map.

\section{HANDY LISTS FOR CHILDREN'S GARDENS}

Ten Popular Flowering Plants for Home and School GARDENS

California poppy, Eschscholtzia Californica

China asters, Callistephus hortensis
Columbine

Cosmos, Cosmos spp.

Four-o'clock

Marigold, Tagetes spp.

1 Some of these may be secured without cost by writing to your congressman. 
Morning-glory, Ipomoea purpurea

Nasturtium, Tropaeolum spp.
Verbena, Verbena spp.

Zinnia, Zinnia spp.

Plants of Different Heights

Five tall plants (three feet and Five middle-sized plants (two feet over) and over)

Cosmos

Hollyhock

Canterbury bells

Foxglove

Larkspur, Delphinium formoPhlox sum

Sunflower (Helianthus orgyalis for screen, or Helianthus cucumerifolizes for hedge)

Tobacco (Nicotiana alata)

Five low plants

Five short plants (one foot high)

Columbine

Poppy, Papaver spp.

Salvia

Cornflower

Marigold

Petunia

Poppy

California poppy

Dwarf nasturtium

Portulaca

Sweet alyssum, Alyssum maritimum

Zinnia ("Red Riding-Hood")

FLowERS BY COLOR

Fïve pink ${ }^{1}$ flowers

Five red ${ }^{2}$ flowers

Cosmos

Aster

Foxglove

Canna

Gladiolus

Phlox

Hollyhock

Poppy, Papaver spp.

Phlox drummondii

1 Don't put pink with orange reds.

2 Don't put magenta with purple and red. 
Five purple flowers

Aster, Callistephus hortensis

Cobaea scandens

Columbine

Petunia

Stock

Five blue flowers

Ageratum

Bachelor's-button

Larkspur

Verbena venosa

Scabiosa caucasica

Five yellow flowers

California poppy

Marigold

Golden glow, Rudbeckia

Sunflower

Zinnia

TEN Popular Vines

Hop, common, Humulus Tupulus; Japanese, Humulus Japonicus

Morning-glory, Ipomoea purpurea or zersicolor

Cobaea scandens

Boston ivy, Ampelopsis tricuspidata
Five white flowers

Canterbury bells

Candytuft

Columbine

Phlox drummondii

Sweet alyssum

Flowers varying in color

Sweet pea

Nicotiana

Morning-glory

Nasturtium

Aster

Verbena

Phlox

Portulaca
Clematis paniculata

Trumpet creeper, Tecoma radicans

Bean (Scarlet runner)

Bittersweet, Celastrus scandens

Gourds, wild cucumber

Tall nasturtium, for climbing (Jupiter, Sunlight, Vesuvius)

Wild Flowers that thrivil inder Cultivation

Columbine Bloodroot Hepatica Mallow Goldenrod 
Plants for Shady Places

Phlox divaricata

Lily of the valley, Convallaria

Anemone Pennsylvanica
Shooting star, Dodecatheon Meadia

Bluebells, Mertensia pulmonarioides

Hardy Ferns suitable for a Garden

Christmas fern, Polystichum Osmunda regalis, Royal fern acrostichoides Polypody, Polypodium vulgare

Sensitive fern, Onoclea sensi- Lady Fern, Asplenium Filixbitis femina

Ten Plants for the Heri Garden (Perennials)

Sage

Lavender

Peppermint

Marjoram

Catnip
Pennyroyal

Rosemary

Horehound

Fennel

Winter savory 
PLANTING TABLE.

\begin{tabular}{|c|c|c|c|}
\hline & \multicolumn{2}{|c|}{ WhEN to sow SeED } & \multirow{2}{*}{$\begin{array}{l}\text { When to Set } \\
\text { out Plants }\end{array}$} \\
\hline & Franes & Outdoors & \\
\hline Ageratum . . & April . . & May. . . . . & $\begin{array}{l}\text { Late May to late } \\
\text { June }\end{array}$ \\
\hline Alyssum, annual . . . & April . . . . & May I to June I 5 & May 15 to June $I_{5}$ \\
\hline Aquilegia (Columbine). & . . . . & June 15 to Sept. I5 & May to Sept. . \\
\hline . . . . & . . . & June 15 to Sept. 15 & May I to June 15 \\
\hline Canterbury bells . . . & $\begin{array}{l}\text { June } 15 \text { to } \\
\text { Sept. } 15\end{array}$ & June 15 to Sept. I 5 & May 15 to June ro \\
\hline Candytuft . & April to May & May I5 to June 15 & May 15 to June 15 \\
\hline $\begin{array}{l}\text { Cornflower (Bachelor's- } \\
\text { button) }\end{array}$ & $\cdot \cdot \cdot \cdot \cdot$ & $\begin{array}{l}\text { April } 15 \text { to June } 15 \\
\text { Aug. } 3^{\circ} \text { to Oct. } 3^{\circ}\end{array}$ & . . . . . . \\
\hline Cosmos, dwarf & April to May & May 15 to June $I$ & May 15 to June 15 \\
\hline Digitalis (Foxglove). . & June to Aug. & June to Sept. . & May I to June I \\
\hline Helianthus (Sunflower) & April to May & May I5 to June 15 & May 15 to June 15 \\
\hline Ipomoea (Moming-glory) & $\cdot \cdot$ & April 15 to June I & $\cdot \cdot \cdot$ \\
\hline Larkspur . . . . . & April to May & May to to June 15 & May 15 to June 15 \\
\hline Marigold . . & April to May & May to June . . . & May 15 to June 15 \\
\hline Nasturtium . . . . & March to May & May I to June 15 & May 15 to June 15 \\
\hline Poppy . & $\cdot \cdot \cdot \cdot \cdot \cdot$ & $\begin{array}{l}\text { April to June } \\
\text { Sept. to Oct. }\end{array}$ & $\cdot \cdot \cdot \cdot \cdot \cdot \cdot \cdot$ \\
\hline Portulaca . . . . . & $\cdot \cdot \cdot \cdot \cdot \cdot$ & April to June & . . . . . . . \\
\hline Salvia. . . . . . & March to May & May . . . . & May to June. . \\
\hline Sweet Pea . . . . . & $\cdot \cdot \cdot \cdot \cdot$ & March to April . . & . \\
\hline Verbena. . . . . & March to May & May . . . . . & May to June. \\
\hline Zinnia . . . . & March to May & May. . . . . & May to June . \\
\hline
\end{tabular}


TWENTY FLOWERS 1

\begin{tabular}{|c|c|c|c|}
\hline $\begin{array}{l}\text { Distance } \\
\text { APART }\end{array}$ & $\begin{array}{l}\text { Height of } \\
\text { PLANTS }^{2}\end{array}$ & $\begin{array}{l}\text { SEASON OF } \\
\text { BLOOM }\end{array}$ & COLOR OF Flower \\
\hline 6 inches & $4^{-8}$ inches & June to Oct. & Blue, white \\
\hline 4 inches & $3^{-6}$ inches & June to Oct. & White \\
\hline 8 inches & $2 \frac{1}{2}$ feet & June to Sept. & $\begin{array}{l}\text { White, yellow, blue, pink, varie } \\
\text { gated }\end{array}$ \\
\hline 12 inches & I-3 feet & October & White, pink, blue \\
\hline 12 inches & $2-21 / 2$ feet & June to Aug. & Blue, white, pink \\
\hline 4 inches & I foot & June to Oct. & White, pink, red, purple \\
\hline Thin out & 2 feet & June to Oct. & Blue, white, pink \\
\hline 12 inches & $2 / \frac{1}{2}$ feet & July to Sept. & White, pink, red \\
\hline 9 inches & 3-4 feet & July to Aug. & Pink, white, blue \\
\hline $9-18$ inches & $3-10$ feet & July to Oct. & Yellow, white \\
\hline Thin out & $15-20$ feet & July to Sept. & Red, white, blue \\
\hline 6 inches & I5 inches & June to Sept. & Red, white, pink, blue \\
\hline 6 inches & $\begin{array}{l}8 \text { inches to } \\
3 \text { feet }\end{array}$ & July to Oct. & Yellow, red, brown \\
\hline 6 inches & I-ro feet & June to Oct. & $\begin{array}{l}\text { Yellow, red, orange, pink, brown, } \\
\text { crimson }\end{array}$ \\
\hline Thin out & $1-2$ feet & June to Aug. & Pink, red, white, yellow, purple \\
\hline Thin out & 4 inches & July to Oct. & Pink, red, white, yellow \\
\hline 18 inches & ${ }^{1} / 2$ feet & Aug. to Sept. & Scarlet \\
\hline Thin out & 6 feet & July to Sept. & All colors \\
\hline 6 inches & 6 inches & June to Oct. & Red, white, pink, blue \\
\hline 6 inches & I-3 feet & June to Oct. & Red, white, pink, yellow \\
\hline
\end{tabular}

1 Dates apply to southern New England.

2 Under best conditions. 
PLANTING TABLE.

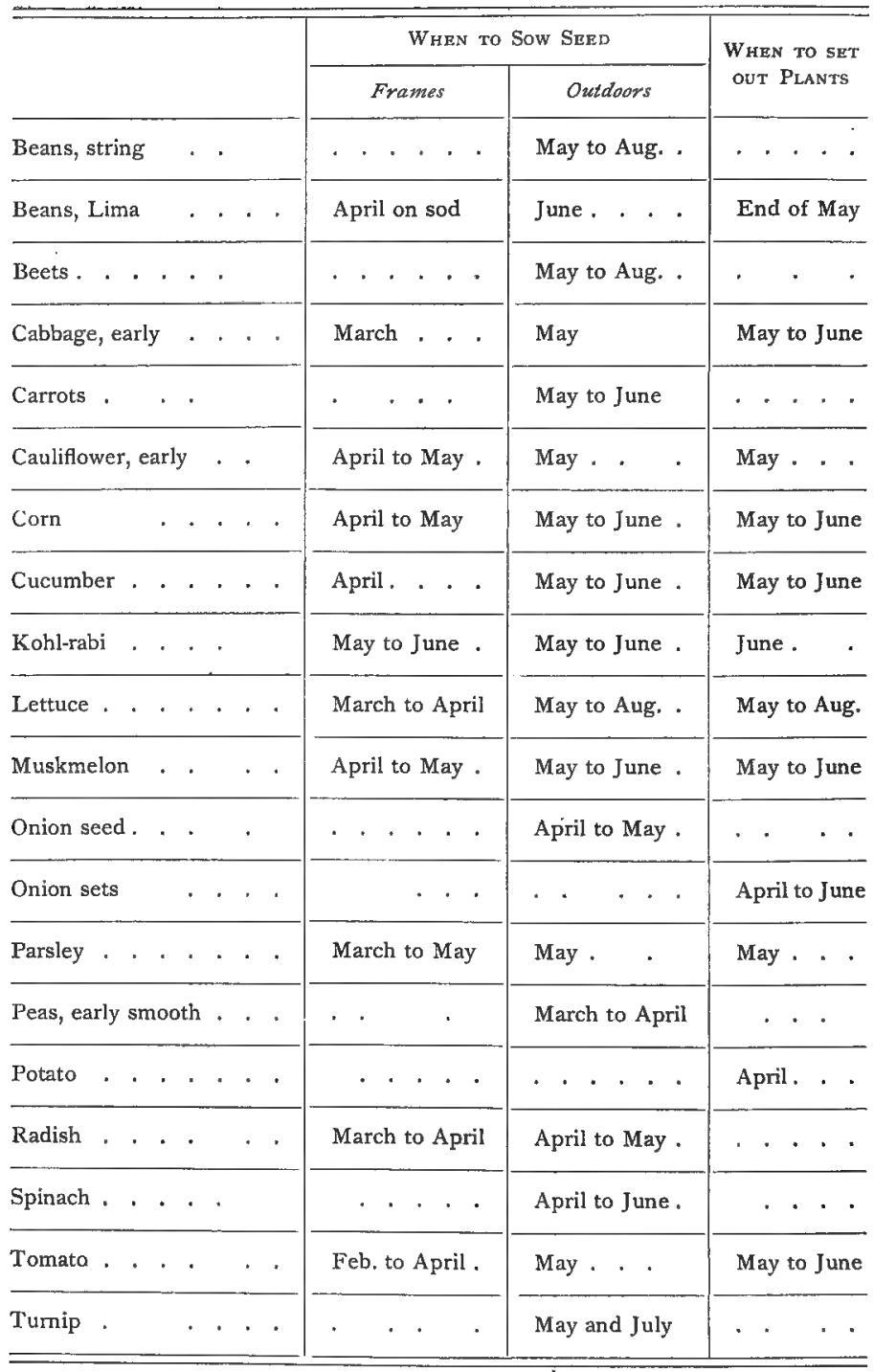


TWENTY VEGETABLES 1

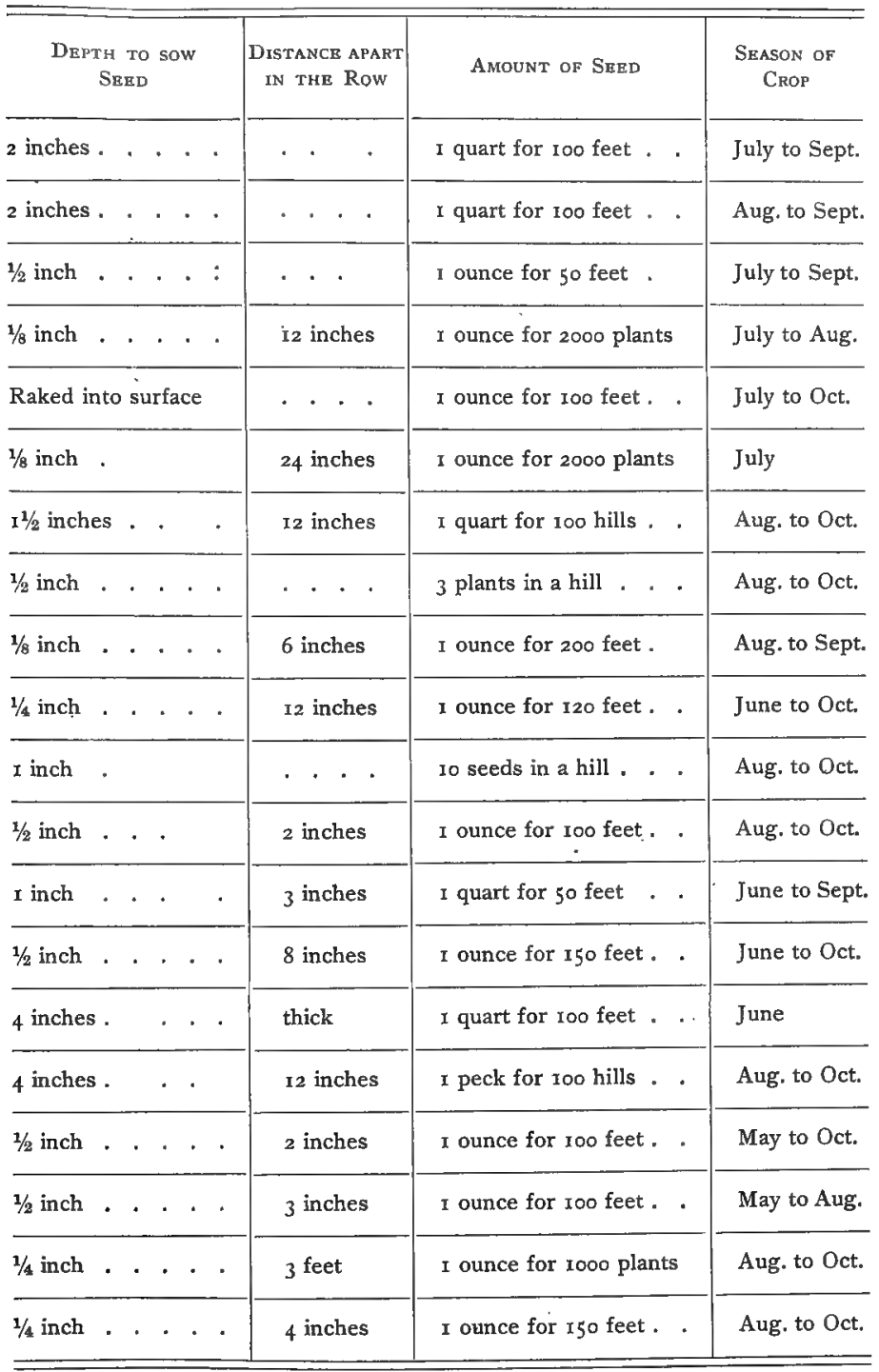

${ }_{1}$ Dates apply to southern New England. 
SUGGESTIVE EXPERIMENTS SUITABLE FOR YOUNG GARDENERंS ${ }^{1}$

\section{Presence of Air in the Soil}

(a) Materials. Soil and flowerpot or can, beaker of water.

Directions. Submerge pot of earth in water. Air bubbles will arise from soil. Same may be shown by clod of earth in water.

(b) Materials. Six beakers, graduate, soil samples.

Directions. Put a measured amount of soil (about $250 \mathrm{ccm}$.) into each beaker. Pour water into the beaker from the graduate (containing a measured quantity) until it rises to the surface of the soil. Find how much water it takes in each case, recording results.

\section{SoIl Temperatures}

Materials. Two or three thermometers.

Directions. Take this excursion on a bright spring day when plowing begins. To take the temperature of a soil, bury the bulb of the thermometer about three inches deep in the soil. Very great care must be taken not to break the thermometer. Leave the thermometer imbedded for from ro to 20 minutes, so as to obtain correct results. Take the temperature of the soil on a northern and on a southern slope, also of clay and sand, of unplowed and freshly plowed fields, and of grass and tilled fields. In each case try to find adjacent soils that are alike except in the two things to be compared.

You will probably find that the one mentioned second in each case is the warmer. Why?

\section{Capillary Rise of Water in SoIls}

Materials. Two small glass plates, three glass tubes (three feet long and from one and one half to two inches in diameter), pan of

${ }^{1}$ Adapted from Public School Agriculture, Massachusetts Agricultural College. 
water, rubber bands, cloth, sand, loam, clay. Lamp chimneys may be used in place of glass tubes.

Directions. (a) Fasten the two glass plates together by a rubber band. Put a thin splint between the plates at one side and set in water. Note the varying height to which the water rises between the plates, and why. Make illustrative drawing.

(b) Put a piece of cloth over the end of each tube and fasten with a rubber band. Fill each with one of the soils, set in a pan of water, and note in which the water rises the most rapidly. Record results as follows :

HEIGHT OF WATER

\begin{tabular}{ll|l|l|l}
\hline \hline \multicolumn{1}{c|}{ TIME } & SAND & LOAM & CLAY \\
\hline One half-hour & $\cdot$ & & \\
One hour . . . & & & \\
One day $\cdot$. & $\cdot$ & & & \\
Two days & $\cdot$ & $\cdot$ & & \\
\hline
\end{tabular}

Continue this for about a week. Note in which the water rises highest, and why. Compare the rise indicated with that of oil in a lamp wick, ink in a blotter, etc.

What is the object of compacting the soil over seeds when planted?

\section{Evaporation From the SoIL}

Materials. Spring balance, three tin cans with holes in the side, string for a bail, soil, fine grass.

Directions. Nearly fill each can with soil, adding equal amounts of water to each. Leave the surface of one can undisturbed. As soon as the surface of the second is dry enough, stir it to a depth of about one inch, and keep it stirred. Cover the top of the third with grass, and weigh. Weigh each can, with the contents, each school day for about two weeks, tabulating the results at the end. 


\section{Drainage}

Materials. Two flowerpots with soil, two pots in which geraniums or other plants are growing, two dishes containing water.

Directions. Set one pot containing a geranium in a dish of water. Plant corn in two pots and stand one of these in a dish of water. Keep water constantly in the dishes under the two pots indicated, and water the remaining two pots in the usual way. Note the effect of the excess of water both on the geraniums and on the germination and growth of the corn. In two weeks empty both pots containing the corn and examine the roots of each.

In which of the pots containing corn do the roots go the deeper? What is the effect of flooding on field crops? on trees?

\section{Effect of Oxygen on Germination}

Materials. Saucers, window glass, sand, clay, beans.

Directions. Fill one saucer with sand and one with clay that has the consistency of putty. The putty condition of clay may be obtained by working over the clay in the hands with water. Plant ro seeds in each saucer. Moisten the sand and press the puttylike clay closely over the beans. Cover each saucer with a pane of glass and put them in a warm place in the room. At the end of three or four days examine the seeds.

\section{Vitality of Seeds}

Materials. Box 4 inches deep and $\mathrm{I} 2$ inches square; some wheat, oats, or other seeds, and sand.

Directions. Pick out $\mathrm{I} 2$ large and $\mathrm{I} 2$ small seeds each from the wheat and oats. Plant in sand, cover the wheat slightly and stick the oats into the soil point down, so that the top comes even with the surface of the soil. Sprinkle a little sand over the top, and water moderately from time to time. When the seeds germinate, note the relative quickness of the two different lots in germinating. Measure the height of each plant, and record as in the corn exercise. 
VIII. Large versus Small Seeds as Crop Provucers

Materinls. One or two papers of some turnip-shaped variety of radish seed.

Directions. Prepare the ground carefully, sort the seeds into two lots according to size, plant large seeds in one row and small ones in another. The rows should be at least one foot apart and the seeds one and one half inches apart in the row. Keep well cultivated and, when large enough, use for luncheon, observing whether the large or the small seeds give the better results.

\section{Potato Scab}

Materials. A dozen scabby potatoes, a small gunny sack, a tenquart pail containing about two gallons of water and one ounce of formalin.

Directions. Put half the potatoes in the sack, mix the formalin and water, set the sack of potatoes in the formalin-water mixture, and let it stand one and one half hours.

Grow the treated and untreated potatoes side by side in the school garden. Do not plant where potatoes have been raised the past year, as the scab often remains in the ground over winter.

\section{Study of Growth of Molds, Mildews, and Blights}

Materials. Cup, bread, potato or lemon.

Directions. Saturate a piece of bread with water and keep it under a cup in a warm place for a few days. Note the white, fluffy fibers (mycelium) at the beginning; later from these arise other fibers which bear tiny, black bodies. Sometimes the ends appear green. These fibers act in much the same way as do those which form the powdery mildew on the pear and grape leaves. The tufts at the end of the delicate fibers contain spores, which correspond to the seeds of other plants. Mold on the potato or lemon can be observed in a like manner. 


\section{StUdy OF BACteria}

Materials. Three test tubes, cotton, boiled potato, fruit or apple sauce, three apples, one partly decayed.

Directions. (a) Fill each tube about one third full of apple sauce. Plug each with cotton. Set one aside. Put the other two into a pail of water and boil for half an hour. After boiling, set one tube aside with the cotton undisturbed. Take the cotton from the third tube and leave it out for half an hour or more, then put it in again. Leave these for a few days, note what happens and account for different results. In canning fruit, is it desirable to leave the fruit uncovered for a few minutes after cooking? Why?

(b) Prick one of the sound apples in several places with a pin. Put the pin into the rotten apple and then into the other sound apple. Repeat this in several places. Set the two sound apples aside for about a week. Note what happens and account for the different results.

\section{NOTES ON SOILS}

\section{Soll Materials}

Gravel. Coarse rock fragments.

Sand. Corresponding in size to grains of sugar.

Silt. Fine soil particles, smooth texture (for example, silicon for cleaning knives).

Clay. The finest rock particles.

Humus. Decaying vegetable and animal substances (for example, decaying leaves and twigs).

\section{SoIL VARiations}

Sandy soil. A mixture of sand and small amounts of silt, clay, and humus, usually poor in nitrogen.

Loam soil. A mixture of one half sand with clay and humus. Fine, sticky. Good for general farming. The more humus the richẹr in nitrogen. 
Clay soil. A mixture of a large proportion of clay with sand, silt, and humus. Likely to be supplied with potash but lacking in phosphoric acid. Heavy, sticky, difficult. Suitable for wheat and corn.

Muck. Large amount of humus mixed with sand and clay; dark brown or black.

\section{Soll Fertility}

A fertile soil will provide for roots three things:

(a) The right conditions of moisture, heat, and air. These will depend largely on the texture of the soil.

(b) Opportunity for the growth of certain living organisms in the soil. The most necessary are the nitrogen-fixing bacteria.

(c) Plant food.

\section{SoIl FEeding}

Plants require seven elements: nitrogen, phosphorus, potassium, magnesium, calcium, sulphur, and iron.

The last four are in every soil sufficiently abundant, but nitrogen, phosphorus, and potassium need to be made available or supplied artificially.

\section{SOURCES OF FoOD}

There are two sources of food: manures and commercial fertilizers. Farm manures include barnyard manure and green manure. Barnyard manures are "complete manures." They contain all the necessary elements of plant foods; they improve the texture; they yield heat. Green manures furnish humus. They return to the soil food that has been incorporated into the plant through its roots from the depths of the subsoil. A cowpea root can be traced to the depth of sixty-one inches. Nitrogen is supplied by certain green crops, such as cowpeas, beans, clover, and other legumes.

Investigations at the Louisiana Experiment Station have shown that one acre of cowpeas turned under gives to the soil nearly 
65 pounds of nitrogen, 2 I pounds of phosphoric acid, and I I I pounds of potash. (United States Department of Agriculture, Farmers Bulletin No. I6.)

VI. Commercial Fertilizers furnish Nitrogen, Phosphoric Acid, Potash, and Lime

Nitrogen is to be obtained from nitrate of soda, sulphate of ammonia, dry fish, cottonseed meal, etc:

Phosphoric acid is to be obtained from phosphate rocks, bones, fish scraps, etc.

Potash is to be obtained from potash mines. Wood ashes contain potash.

Lime is supplied to the soil in the shape of quicklime. It is valued chiefly for its effect on texture, making clay soils mealy and sandy soils more adhesive.

\section{General Conclusions}

Small grains - wheat, oats, and barley - can easily obtain phosphoric acid and potash, but they are weak in obtaining nitrogen and are benefited, therefore, by the addition of nitrates.

Legumes collect nitrogen from the air, but take from the soil lime, phosphoric acid, and potash. Hence these last must be supplied by manures.

Root crops are unable to use the insoluble mineral elements in the soil. Hence all the chief elements may be advantageously applied in a state ready for use.

Stem and leaf crops in particular require nitrogenous food. A healthy green foliage indicates good nourishment; pale yellowish green indicates lack of nitrogen.

Fruit trees are slow-growing plants and do not need quickacting fertilizers. Small fruits are rapid-growing plants and are benefited by readily soluble fertilizers. 


\section{EXERCISES SUITABLE FOR YOUNG GARDENERS}

A number of experimental beds were planted at one school ${ }^{1}$ as follows :

(a) Crimson clover, - to illustrate the immediate effect of pollen on fruit.

(b) Pea vine, the successive crops spaded in, - to study the pea vine as a nitrogen collector.

(c) Pea vine, the successive crops gathered and the vines pulled up, - to observe the poverty of the soil in nitrogen.

(d) Peas treated with a chemical fertilizer, - to compare these crops with those of $(b)$ and $(c)$.

(e) Cabbage, kale, kohl-rabi, collards, cauliflower, and brussels sprouts, - to show the variation obtained from the ancestral cabbage by cultivation.

$(f)$ Corn for several successive years, to illustrate deterioration in crops through exhaustion of the soil.

(g) Flax.

(h) Grains.

(i) Strawberry patch.

\section{BOYS' AND GIRLS' CLUBS}

Boys' and girls' agricultural clubs are being organized on all sides for corn, cotton, and potato growing and for live-stock study, bird study, and home culture. All of these clubs are more or less agricultural in their general character. Such a club is an association of young people who enter into competition to determine which can grow the largest or the best crop on a certain area of ground, according to definite rules for the planting, cultivation, and exhibit of their product. These clubs have, above all, developed in boys and girls initiative and the power of assuming responsibility.

Collectively they have learned the value of organized effort, of coöperation, and of compromise; and the social instinct has been

1 Rice School, Boston. 
developed in them, - a matter of great importance in rural districts, where the isolated condition of the people has long been a great hindrance to progress. ${ }^{1}$

The accompanying letter speaks for itself in showing how one agricultural college is organizing corn and potato clubs.

\author{
Massachusetts Agricultural College \\ Department of Agricultural Education \\ Amherst, Massachusetts
}

To the Boys and Girls of Massachusetts :

You are invited to join a Corn Club or a Potato Club. My object in asking you to join one of these clubs is to help you to learn more about raising corn and potatoes. If you wish to join, you must agree to plant, cultivate, and harvest the crop without any help. After the crop is gathered there will be a contest for premiums for the best corn and the best potatoes.

The corn and potatoes that win prizes at home will be taken to Worcester in November to compete for prizes at the Corn Exposition. Give your name and post-office address to your teacher or superintendent as soon as you make up your mind to join.

As soon as your names are sent to me I shall send you some directions for planting and cultivating. Every member of the Corn Club will get a half-pint of corn, and every member of the Potato Club will get three Green Mountain potatoes free.

Very respectfully yours

W. R. Hart

1 United States Department of Agriculture, Farmers' Bulletin 15.385. 


\section{IN DEX}

Addams, Jane, 23

Agricultural Department, 209

Agricultural League, 204

Agriculture, advance in, 26; in America, 196, $208 \mathrm{ff}$; in Europe, $201 \mathrm{ff}$; new; $212 \mathrm{ff}$.

Allston garden, I87

Arbor, 155

Back yards, I $56 \mathrm{f}$.

Bacon, Sir Francis, 67

Barometer, I 50

Beans, raising of, I $3 \mathrm{f}$.

Bees, I $47 \mathrm{ff}$.

Beets, raising of, $\mathrm{I}_{4} \mathrm{f}$.

Benefactors of the garden, I $35 \mathrm{ff}$.; ladybird, $135 \mathrm{f}$.; tiger beetle, 136 ; ichneumon fly, $136 \mathrm{f}$. ; dragon flies, 137 ; toads, 137 ; earthworm, $138 \mathrm{ff}$.; birds, I $40 \mathrm{f}$.

"Better-Farming Specials,". 2 ro

Bird fountains, I $45 \mathrm{ff}$.

Bird houses, $144 \mathrm{f}$.

Birds, I 40 f.; protection for, 142 ff.

Blight, I3o

Books and pamphlets, 2 I 5 f.

Bordeaux mixture, 130

Briggs, Le Baron, 37

Brooks, John Graham, 202, 204, 205

Bulbs, $96 \mathrm{ff}$., 180,182

Cabbage, raising of, I $5 \mathrm{ff}$.

Calendar, school-garden, I8o ff.

Cannas, 97

Carlyle, Thomas, I

Carrots, raising of, i $7 \mathrm{f}$.

Caterpillar, giant green, 125 ; cabbagé, I $32 \mathrm{f}$.

Cauliflower, II 7

Children, as producers, $2 \mathrm{ff}$.

Children's Farm, New York City, $76,8 \mathrm{I}, \mathrm{I} 86$

Cleveland, Ohio, 186
Clubs, agricultural, $23 \mathrm{f}$.

Cold frame, $65,93 \mathrm{ff}$.

Competition, $37,3^{8}$

Composition, correlated with gardening, I $60 \mathrm{f}$., I $66 \mathrm{f}$.

Compost heap, $59 \mathrm{f}$.

Coöperation, I7; as a test of efficiency, 24 ; as a developer of initiative, $25 \mathrm{f} ., 35$; in the school, 30 , $31,38 \mathrm{ff}$.; value of, in employees, 33 ; with the community, 34 ; lack of, in schools, $36 \mathrm{f}$.; example of, 53 ; in gardening, 69 f., I94; against pests, I 3 I, 209; moral and social value of, 205; natural to man, 208 ; training children in, $2 \mathrm{I} 3$

Coöperative agriculture in Europe, $203 \mathrm{ff}$.

Coöperative dairies, 204

Coöperative mills, 204

Coöperative organization, 2 Io

Corn, 183

Covers, glass, $92 \mathrm{ff}$.

Crocuses, 97

Crops, catch, 85 ; cover, 85 ; care of, at early stage, Ioo

Cultivation, IOI $\mathrm{f}$.

Daffodils, 97

Dahlias, 97

Darwin, Charles R., $\mathrm{x}_{38}$, 178

Dragon flies, I 37

Drawing, correlated with gardening, I 70

Drills, gI

Dust blanket, Ior

Earthworm, I38 ff.

Eliot, Charles W., 45

Elm trees, 48

Emerson, Ralph Waldo, r 28

Exhibits, vegetable, 34, I83

Experiments, $224 \mathrm{ff}$. 
Farm, model, 27

Farmer, average, $199 \mathrm{ff}$., $206 \mathrm{f}$.

Farming, intensive, 131, $197 \mathrm{f}$.

Fertilizers, 56 f., 230

Freesias, 97, I81

Fungous diseases, 84 f., I I 4, I $29 \mathrm{f}$.

Garden, social value of a, I I ff. ; an English, $15^{8}$

Garden line, $63 \mathrm{f}$.

Gardening, place of, in school program, I $5,16_{3} \mathrm{f}$; ; influence of, in schoolroom, 16; necessity of organization in, 16 ; as a means of livelihood, 34; correlated with other subjects, $63,88,163 \mathrm{ff}$., $172 \mathrm{ff}$.; suitable dress for, $8 \mathrm{I}$; practical issues in, I6I f; appeal of, I62 f.

Gardens, school; see School gardens

Geography, correlated with gardening, $168 \mathrm{f}$.

Gilder, Richard Watson, I $54 \mathrm{f}$.

Gladioli, 97

Gladstone, William E., 60

Group work, $38 \mathrm{ff}$.

Herbs, 126,219

Hodge, Clifton F., I 4 I

Hotbed, $95 \mathrm{f}$.

Hyacinths, 97

Ichneumon $\mathrm{fly}, \mathrm{I} 36 \mathrm{f}$.

Initiative, $72 \mathrm{ff}$.

Insect pests, 84 f., I I6, I 30 ff., 209; potato beetle, I3I; squash bug, I31 ; cabbage caterpillar, I32; hibernation of, I33 f., 136; corn worm, I 34 ; cucumber beetle, I34; cutworm, I 34 ; rose beetle, 134 ; tomato worm, I34; aphids, 135

Iowa experiment station, 54

Irrigation, I04 ff.

James, William, 212

Kropotkin, 203, 207

Labeling, 92, $18 \mathrm{I}$

Ladybird, I35 f.

Leguminous plants, 58,85

Lettuce, raising of, I $8 \mathrm{ff}$.
Lima beans, planting, 9I

Lists for garden, $216 \mathrm{ff}$.

Loam, 55

Manuring, green, 85

Market garden, visit to a, $68 \mathrm{f}$.

Marthas Vineyard, 105

Mathematics, correlated with gardening, 63,88, I $64 \mathrm{f}$.

Mellaerts, Abbé, 203

Methods of teaching, modern, $176 \mathrm{ff}$.

Mulch, 104

Natural history, correlated with gardening, $172 \mathrm{ff}$.

Nitrate of soda, 121, 122, 123,124

Nitrogen, 58, 83

Onions, raising of, i $20 \mathrm{f}$.

Orchard, miniature, $\log \mathrm{f}$.

Order, 6

Parsley, raising of, I 2 I $\mathrm{f}$.

Pergola, I 55

Perils, national, 209

Phosphoric acid, 58

Planting, 30, 82 ff., $180 \mathrm{ff}$.; economy in, 83 ff.; devices in, 86 ; depth of, $89 \mathrm{f}$; indoor, $92 \mathrm{f}$.

Planting box, 90

Planting table, $220 \mathrm{ff}$.

Playgrounds, combined with garden, $48 \mathrm{f}$.

Poison, I 6 , I 31

Potash, 58,83

Potatoes, 84 f., 130 , I82

Poultry, 149

Poweli, George T., I 40

"Pricking out," 94

Proteids, 83

Radishes, raising of, I $22 \mathrm{f}$.

Rain gauge, I 50

Rice, experiment in raising, $73 \mathrm{f}$.

Rice School, 59, 80, I 70, 195, 231

Root, club, I 16

Root crops, 83

Root maggot, I 2 I, I 22

Roots, 100

Rot, black, I I 6 
Rotation of crops, $82 \mathrm{ff}$.

Rust, I I 4, 130

Saint-Gaudens, 66, 178

Scab, potato, $84 \mathrm{f}$, I 30

School gardens, from an educational standpoint, I 5; definition of, 17 ; difficulties of, 18,5I; successful experiments in, 20, 39 ff., I95; social value of, 22 ; in April, 30 ; ownership of, 31 ; coöperation in, $3 \mathrm{r}, 6 \mathrm{f}$.; incidental values of, $33 \mathrm{f}$; opportunities in, 43 ; suitable situations for, $47 \mathrm{f}$. ; in parks, $50 \mathrm{f}$. ; protection of, $52 \mathrm{f}$.; laying out of, 6 I ff.; plan of, 65 ; false ideas of arrangement in, 7I; surface of, I00 $\mathrm{f}$. ; fruit in, I08 f.; accessories of, I $42 \mathrm{ff}$; ; borders of, I 54 ; vacation work in, $183 \mathrm{ff}$.; record of events in, $186 \mathrm{f}$.

School-garden calendar, a, I $80 \mathrm{ff}$.

Science correlated with gardening, $172 \mathrm{ff}$.

Scillas, 98

Seed crops, 83

Seeds, $27 \mathrm{f}$; testing, $87 \mathrm{f}$. ; planting, $89 \mathrm{ff} ., \mathrm{I} 80 \mathrm{ff}$.

Sentiment, 5

Shaler, Nathaniel S., 36

Shrubs, transplanting of, I $08 \mathrm{f}$. ; varieties of, I IO

"Skimming the land," 57

Smut, I 30

Spencer, John W., 46

Spinach, I 23

Sprays, 130, I 32

Soil, tests of, $54 \mathrm{f}$.; enrichment of, 56,85 ; preparation of, $88 \mathrm{f}$.; ideal texture of, 89 ; for cold frame, 94 ; notes on, $228 \mathrm{ff}$.

Stevenson, Robert Louis, I 29

Street sweepings, 57

Summerhouse, I 55

Sundials, I 5 I ff.

Teachers, duties of, $22 \mathrm{ff} ., 30,75,185$, 195; opportunities of, 34,42

Thaxter, Celia, 108, 138

Thistle, Russian, I 28

Tiger beetle, ${ }_{3} 6$

Toads, $137 \mathrm{f}$.

Tomatoes, $\mathrm{I}_{23} \mathrm{ff}$.

Tonic for plants, 104

Tools, $76 \mathrm{ff}$

Transplanting, 94 ff.; seedlings, 106 ff.; shrubs and trees, I08 ff.

Tulips, 97

Vegetables, I I 2 ff.; beets, 84 , I 14 f., I82; onions, 84,86 , I20 f., I82; parsnips, 84,86 , I I 7, I 82 ; potatoes 84 f., I 30 , I 82 ; turnips, $84,85,86$, I 80 ; carrots, 86 , I $7 \mathrm{f}$.; lettuce, 86,94 , I I 8 ff., I82; radishes, 86 , I 7 , r 22 f., I82; spinach, 86,94 , I 23 , I 80 , I 82 ; cabbage, 94 , I I 5 ff., I72, I 82 ; parsley, 94, I 2 I f., I 82 ; tomatoes, 94, I $23 \mathrm{ff}$., I 82 ; beans, II 3 f. ; cooking of, I7 I f. ; corn, 183

Washington, George, I 5 I f., I 65

Watering, science of, I03 $\mathrm{f}$.

Weeds, $100 \mathrm{f}$., $\mathrm{I} 27 \mathrm{ff}$.

Window boxes, 46, $92 \mathrm{f}$.

Woodworking, 8I, I 5 I 


\section{ANNOUNCEMENTS}




\section{A GRIGULTURE FOR BEGINNER S}

By C. W. Burкeтt, recently Director of Agricultural Experiment Station, Manhattan, Kans; F. L. Stevens, Professor of Biology in the North Carolina College of Agriculture and Mechanic Arts; and D. H. HILL, President of the North Carolina College of Agriculture and Mechanic Arts

I $2 \mathrm{mo}$, cloth, 339 pages, with color pictures, illustrated, 75 cents

book for common schools in recent years has aroused such widespread interest and been so universally commended as this little volume. Its adoption in two great states before its publication, and in still another state immediately after its appearance, indicates the unusually high merit of the work.

The authors believe that there is no line of separation between the science of agriculture and the practical art of agriculture, and that the subject is eminently teachable. Theory and practice are presented at one and the same time, so that the pupil is taught the fundamental principles of farming just as he is taught the fundamental truths of arithmetic, geography, or grammar.

The work is planned for use in grammar-school classes. It thus presents the subject to the pupil when his aptitudes are the most rapidly developing and when he is forming life habits. It will give to him, therefore, at the vital period of his life a training which will go far toward making his life work profitable and delightful. The text is clear, interesting, and teachable. While primarily intended for class work in the public schools, it will no doubt appeal to all who desire a knowledge of the simple scientific truths which lie at the foundation of most farm operations.

The two hundred and eighteen illustrations are unusually excellent and are particularly effective in illuminating the text. The book is supplied throughout with practical exercises, simple and interesting experiments, and helpful suggestions. The Appendix, devoted to spraying mixtures and fertilizer formulas, the Glossary, in which are explained unusual and technical words, and the complete Index are important.

In mechanical execution - in the attractive and durable binding, in the clear, well-printed page, and in the illustrations - the book is easily superior to any other elementary work on agriculture.

\section{GINN \& COMPANY Publishers}




\section{HODGE'S}

\section{NATURE STUDY AND LIFE}

By Clifton F. Hodge, Professor of Biology in Clark University, Worcester, Mass. With an Introduction by Dr. G. STANLey Halz

Cloth, 5 r 4 pages, illustrated, \$r.50

\section{OUTLINE FOR HODGE'S NATURE STUDY AND LIFE \\ Paper, 32 pages, ro cents}

$\mathbf{N}$

ATURE STUDY AND LIFE has twice formed the basis for nature-study courses in the Clark University Summer School ; it has further stood the more practical test of teachers' institutes in various states; and, finally, its most important suggestions have been tried thoroughly in the schoolroom. The work contains the results of five years' special study. In the point of view, in the selection of the subject-matter, and in the presentation of methods of conducting the work, this book marks a definite advance over other publications on the subject of nature study.

It is a determined reaction against the special and technical, and forms an earnest effort to give fundamental and universal interests in nature their deserved place in our system of public education. After presenting this point of view clearly in the opening chapter, the book takes up concrete lessons on the animals and plants that form the natural environment of the home, and group themselves most closely about the life and interests of the child. Each form is studied alive and at work, as a life story to be read at first hand in nature and especially in its relations to man.

The book is a $12 \mathrm{mo}$, bound attractively in blue and gold, so that the volume is eminently appropriate in appearance not only for the schoolroom but also for the home reading table or bookshelf. The illustrations are of unusual value and interest. The whole plan and make-up of the book have been kept in as close harmony as possible with the excellence and high character of the text itself.

From the School Review, Chicago

The publishers do not overstate the merits of this book when they say that it is one of the most notable nature-study books now published. The emphasis is upon nature, not upon study, - and life is never sacrificed to some fancied correlation or some narrow scientific application. The illustrations are singularly felicitous in that they show us not only nature but also human nature in the persons of interested girls and boys. This is a book for the home as well as for the school. It is scientific in its knowledge, simple in its phraseology, and fascinating in its style.

\section{GINN \& COMPANY Publishers}




\section{THE GULICK HYGIENE SERIES}

By Luther Halsey Gulick, M.D.

Recently Director of Physical Training in the Public Schools of New York

\section{Book I. GOOD HEALTH 40 cents}

HERE, tucked away in the lines of an interesting story, the young reader finds out how to care for the eyes, ears, and teeth, how to get impure air out of a room and pure air in, why he should go to bed early and regularly, and how to perform these duties intelligently.

\section{Book II. EMERGENCIES 40 cents}

WHAT to do in case of accidents, and particularly how to avoid them, is the burden of this second volume.

The water treatment of burns and the soap-and-water treatment for ivy poisoning are points of particular interest.

\section{Book III. TOWN AND CITY $5^{\circ}$ cents}

Crvic hygiene is here taught in a most alluring manner. Boys and girls learn that there are some small responsibilities that they may shoulder at once, and thus protect themselves from the dangers of impure milk, "tuberculosis, overcrowded houses, accumulated garbage and. rubbish, and many other evils of town and city life.

\section{Book IV. THE BODY AT WORK 50 cents}

"The Body at Work" treats such matters of physiology as were too difficult or too technical to be discussed in "Good Health." Muscular exercise forms an avenue of interest through which the student is taught all necessary knowledge and much that is new concerning respiration and digestion, bone and muscle habits, etc.

\section{Book V. CONTROL OF BODY AND MIND 50 cents}

"Control of Body and Mind" is written with the conviction that such subjects as Attention, Choice, Will Power, Habit, and Character should be and can be made both interesting and inspiring to young people. In the treatment of each subject, function rather than nerve anatomy receives the most attention.

\section{Two-Book SERIES}

GOOD HEALTH (Same as in the five-book series)

\section{THE BODY AND ITS DEFENSES 65 cents}

PREsents the vital facts of physiology and hygiene, so arranged as to follow the material in "Good Health" and form a complete two-book series.

$146 \frac{1}{2}$

\section{GINN AND COMPANY Publishers}




\section{AMONG COUNTRY SCHOOLS}

By O. J. KERN

Superintendent of Schools, Winnebago County, Illinois I 2 mo, cloth, 366 pages, illustrated, $\$$ I. 25

\section{AN OUTLINE OF QUESTIONS FOR KERN'S AMONG COUNTRY SCHOOLS. Io cents}

THE author's endeavor in preparing this work has been to create a new ideal in the training of the country child.

The book is the result of seven years of very earnest thought and hard work in an endeavor to secure for the country child his rights so far as an educational opportunity is concerned. The country school should have that freedom which country. life affords. This book has but little to say about the mechanics of school management.

In the training of children and the development of character no greater opportunity can be offered than that now presented to the teacher in the country school. The author hopes that this book will prove suggestive to the teacher and school officer who are striving for the spiritualization of country life through the medium of the school. He believes that a careful reading of its pages will show a practical way of interesting the "farm child through farm topics."

Some of the chapter titles, indicating the suggestions given in this distinctly novel treatise, are :

THE RIGHTS OF THE COUNTRY CHILD

OUTDOOR ART - BEAUTIFYING SCHOOL GROUNDS

INDOOR ART AND DECORATION

A FARMER BOY'S EXPERIMENT CLUB

THE COUNTRY SCHOOL AND THE FARMERS' INSTITUTE 







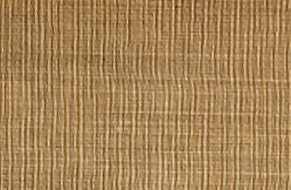

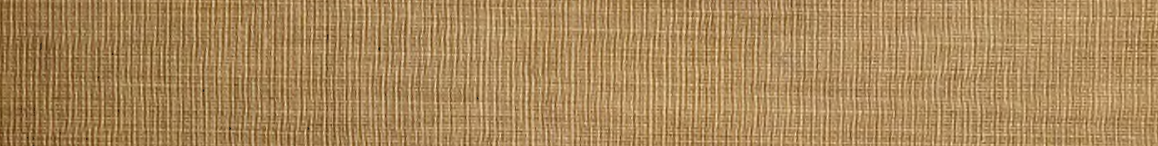

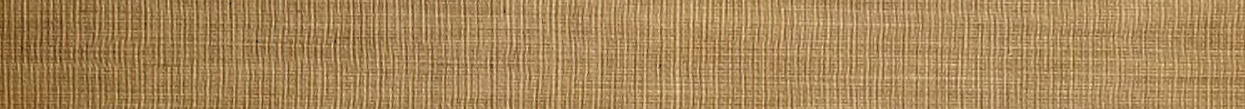

-

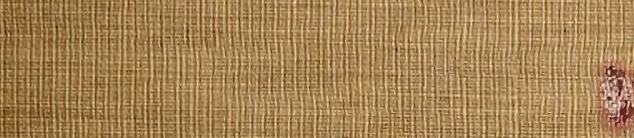

-

(1)

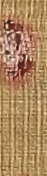

Lente

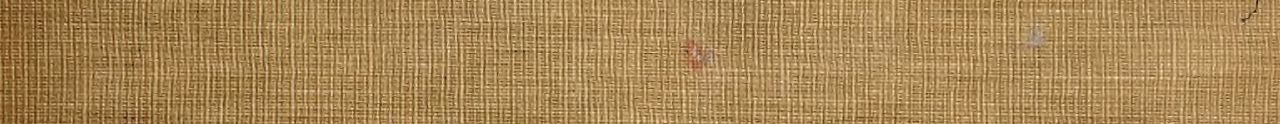
H.

H. Hem

-

H.

mat -

- m. HIm H. D

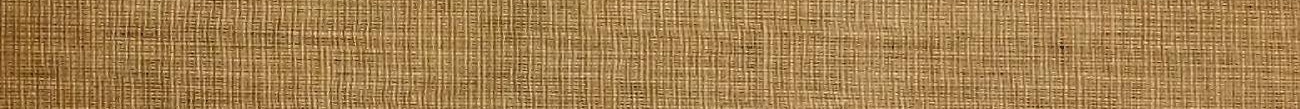

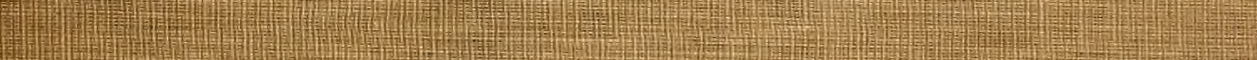
Ham H. W. H. (t) Heme H. me 